\title{
Regression results of the union impact on pay levels in New Zealand public service
}

by

Goldie Feinberg-Danieli

A thesis

submitted to the Victoria University of Wellington

in fulfilment of the requirements of the degree of

Master of Commerce and Administration

Victoria University of Wellington 


\section{Acknowledgements}

In the course of working on this thesis, a number of people played their part in helping me along the way. I would like to acknowledge the support of numerous people who helped me to accomplish my goal.

I would like to begin by thanking my husband Chen and my two children, Aimee and Tom, for their constant support and for encouraging me to complete this work.

I would like to acknowledge the effort of my supervisor Stephen Blumenfeld, who has provided me with valuable advice, support throughout and important comments. I am particularly grateful to John Davies for allowing me to take time off to complete this journey. I would like to thank the State Service Commission' team for granting permission to use their survey data to conduct this study.

I am indebted to my friends and colleagues, Sophia Lum, James Upton and Noelle Donnelly, for the endless support and encouragement, for the valuable comments and generosity. My heartfelt thanks to you all for your tolerance, patience and belief in me. Finally, I extend thanks to the examiners, for their time. I hope you enjoy it! 


\section{Important Disclaimer}

Victoria University of Wellington and its Council, or its members, staff, employees, students and agents undertake no duty of care in contract, tort, or otherwise, to users (whether direct or indirect) of this ("Regression results of union impact on pay levels in the New Zealand public service"), and make no warranties or representations of any kind in relation to any of its contents.

("Regression results of union impact on pay levels in the New Zealand public service") is only available on the basis that all users of it, whether direct or indirect, must take appropriate legal or other expert advice in relation to their own judgment and such legal or other expert advice.

Under no circumstances will Victoria University of Wellington and its Council, it members, staff, employees, students or agents be liable in any way whatsoever, whether in contract, tort (including negligence), or for breach of any statuary or regulatory duty (whether direct or indirect) of this ("Regression results of union impact on pay levels in the New Zealand public service"), or any loss or damage whatsoever arising directly or indirectly as a result of the use in any way of this ("Regression results of union impact on pay levels in the New Zealand public service").

Each exclusion in the clauses of this disclaimer and each protection given by it is to be constructed as a separate exclusion applying even for any reasons the exclusions or protections are held inapplicable in any circumstances. 


\begin{abstract}
International studies almost uniformly conclude that union members receive higher wages than their non-union counterparts. This study investigates differences between collective and individual salaries using the New Zealand State Services Commission's Human Resources Capability Survey 2005. It explores the impact of collective bargaining on pay by controlling for a large number of employee and employer characteristics. As very little research has been carried out on the subject in New Zealand, I focused on the international literature in order to identify the major factors that explain the magnitude of union/non-union wage differential. Major industrial changes, which have shaped the NZ public service bargaining structure and its outcomes are identified.
\end{abstract}

A range of statistical tests are used to examine the pay differences between collective and individual agreements in New Zealand public service. I, first, carry out basic comparisons of the average collective and individual wages across gender, employment type, occupations, ethnicity, age, employer size and tenure, followed by numerous multivariate regressions to work out the true contributing factors to the union/non-union wage differential. Finally, I analyze the results in the unique NZ context to allow new ideas and theory to emerge and compare it to international trends.

Looking at the basic comparisons, I found that, in the New Zealand public service, employees on individual agreements earn significantly higher wages then those who are covered by collective agreements. However, multivariate analyses have revealed a different picture. The study found that occupational composition is the largest contributor to the variability in collective/individual pay in NZPS. With the exception of the senior, high skilled and specialised employees, no pay differential was found between collective or individual agreements in the New Zealand public service. 


\section{Table of Contents}

Acknowledgements

Important Disclaimer

ii

Abstract

Chapter 1: Introduction 1

1.1. Problem Statement 1

1.2. Research Context 1

1.3. Research Gap 2

1.4. Methodological Framework 4

1.5. Research Questions 5

1.6. Outline of the Thesis 5

$\begin{array}{lr}\text { Chapter 2: Employment legislation context } & 8\end{array}$

2.1. Introduction to the Chapter 8

2.2. Prior State Sector Act 1988

2.3. The State Sector Act $1988 \quad 10$

2.4. Employment Contracts Act $1991 \quad 14$

2.5. Employment relations Act $2000 \quad 17$

$\begin{array}{ll}\text { Chapter 3: Bargaining structure } & 19\end{array}$

3.1. Introduction to the Chapter 19

3.2. Public service 19

3.3 Pay setting in the public service 21

Chapter 4: Literature review $\quad 26$

4.1. Introduction to the Chapter 26

4.2. New Zealand public service context 35

4.3. Outlines of the literature review 36

Chapter 5: Methodology framework 38

5.1. Introduction to the Chapter 38

5.2. Methodology 38

5.3. Data source 39

5.4. Limitations of the data 40

5.5. Variables used in the analyses 40

5.6. Model fit 41

5.7. Regression diagnostics $\quad 42$

5.8. Preliminary data tests 43

5.9. Relationships between the variables 44

5.10. Setting the scene 47 
Chapter 6: Findings $\quad 48$

6.1. Introduction to the Chapter 48

6.2. Research purpose 48

6.3. Dataset characteristics 49

6.4. Unionization 49

6.5. Analyses 51

6.6. Regression results $\quad 54$

6.7. Summary 62

$\begin{array}{ll}\text { Chapter 7: Conclusions and implications } & 63\end{array}$

7.1. Introduction to the Chapter 63

$\begin{array}{ll}\text { 7.2. Means comparison } & 63\end{array}$

7.3. Multiple regressions 64

Chapter 8: Areas of Further Research $\quad 67$

$\begin{array}{ll}\text { 8.1. Introduction to the Chapter } & 67\end{array}$

$\begin{array}{lr}\text { References } & 69\end{array}$

$\begin{array}{lr}\text { Appendices } & \mathbf{7 8}\end{array}$ 


\section{Introduction}

\subsection{Problem Statement}

The purpose of this research is directed to further the knowledge of collective bargaining and its impact on pay levels in the New Zealand public service. In particular, it investigates the collective/individual wage differential, by controlling for a large number of employee and employer characteristics using the New Zealand State Services Commission's Human Resources Capability Survey 2005. This is accomplished by first gaining a better understanding of legislative and administrative changes in NZ, more precisely, of the historical developments of employment relations in the public service that shaped the current bargaining structure and its outcomes. Second, the research explores the nature of pay setting procedures and union involvement in them. It then identifies the differences in wages between collective and individual agreements negotiated in a given bargaining environment, and examines the factors that contribute to these differences. The research is empirical in nature and estimates the collective/individual wage differential using numerous multivariate regressions. The goal of this research is to understand whether or not such a gap exists, the nature of it and what are the contributing factors to the possible gap in the environment of the public service in New Zealand.

\subsection{Research Context}

Wage bargaining has been identified elsewhere as a primary function of unions. It follows that the union/non-union wage differential is considered an important measure of union power (Layard and Nickell, 1985; 1986). There is also an enormous body of empirical research internationally on the union/non-union wage differential, using both micro- and macro-economic models, demonstrating that union members typically receive higher wages than their non-union counterparts(Freeman, 1980;Lewis, 1986;Card, 1991; Mishel and Walters, 2003).At the same time, though, it is known that unions also have a considerable impact on the wages and employment conditions of 
many non-unionized workers as well (Freeman \& Medoff, 1984; Mellow, 1981; Blanchflower \& Freeman, 1992; Belman \& Voos, 2004).

Following the State Sector Act 1988 and under the impact of Employment Contracts Act 1991, each department in the public service has full control over the determination of wages and other conditions and is given very clear criteria in regards to what factors to consider when setting wages. These factors relate only to the individual department and include the ability to address organizational outcomes, pay within current baselines, recruitment and retention issues, and comparisons with others within the department. Such bargaining structures have enhanced management discretion and lessened employee involvement through their union. Pay terms and conditions are set by remuneration systems that are put together with the management prospective in mind. The removal of pay from collective agreements has removed one of the main organizing functions of the union, while the emphasis on departmental remuneration systems has contributed to discrepancies between departments.

Also, although the ERA curtails the ability of employers to extend collective agreement coverage to non-union members, the free riding effect still occurs. New Zealand public service was found to be highly unionized (May and Lonti, 2003) with occurrence of skill shortages (SSC HRC survey report, June 2005). Where union density is high, it is likely that the provisions of negotiated collectives will extend to similar employees who are not covered. Furthermore, where there is occurrence of skill shortages, the union rate is likely to have a strong influence on the pay and conditions employers with nonunionized employees would need to offer in order to attract staff. In both situations, it would lead to a reduction of the collective/individual differential.

\subsection{Research Gap}

There is wide agreement within the literature that union members typically receive higher wages than their non-union counterparts. (Flanders, 1970; Freeman \& Medoff, 1984; Mellow, 1981; Blanchflower and Freeman, 1992; Kornfeld, 1993; Miller and Mulvey, 1994, 1996; Miller, Mulvey and Neo, 1999; Wooden, 2001b; Peetz, 2001; Belman and Voos, 2004). 
Although there is an enormous body of empirical research internationally on the union/non-union wage differential, it is yet to be calculated in New Zealand. In addition, most of the extant literature on union wage effects is focused on the union/non-union wage differential in the private sector. Only few such studies consider this phenomenon in the public sector and public service, in particular. Given the growing importance of public sector unionism, more studies are expected to be done in the future.

New Zealand's bargaining environment is unique compared to many other industrial countries. In New Zealand, there are employees who are union members but are not covered by collective agreements, contrary to the more common occurrence in other countries (e.g., USA and Canada) where non-union members are often covered by collective agreements. Therefore, in New Zealand the union/non-union pay differential should be more precisely called the "collective versus individual" pay differential. The literature is characterized by a number of apparent contradictions in terms of union/non-union wage differential. Studies have found both union and non-union premia, that the differential has changed over time, and varies by worker type, industry, firm and occupation. In addition, it is known that unions have a considerable impact on the employment conditions of many non-unionized workers as well, substantially reducing the union/non-union wage gap (Freeman \& Medoff, 1984; Mellow, 1981; Blanchflower \& Freeman, 1992; Belman \& Voos, 2004).

A large number of studies, using both micro- and macro-economic models, demonstrate that union members receive higher wages than their non-union counterparts (Freeman, 1980; Lewis, 1986; Card, 1991; Mishel \& Walters, 2003). On the contrary, Peetz (2001) finds that Australian employees on collective agreements often experience inferior terms and conditions to employees on individual contracts, in fact having a "non-union premium". He argues that, in order to induce employees to forsake union coverage, employers may offer employees a higher wage through individual bargaining for the same type of work. Studies of union avoidance in the United States during the past half century come to the same conclusion (Zigray, 2005; Logan, 2006).

Blanchflower and Bryson (2004) note that the union premium is sensitive to estimation techniques and data richness. A number of studies point to the conclusion that union- 
nonunion differentials can be explained by employee related characteristics (Cristie, 1992; Hansen, 1998; Hirsh \& Macpherson, 2001). Other researchers focus on firm specifics, such as workplace size, and conclude some large differentials reported on in the earlier studies are the result of omitted variable bias and, specifically the failure to adequately control for workplace differences especially important in a decentralized bargaining environment (Freeman \& Medoff, 1984).

This study is able to include both individual level data and some workplace related specifics, such as organization size and location. Within this study, I have adapted factors used to explain union/non-union wage differentials that have been recognized by previous research as relevant to the estimation of the collective/individual wage differential in the NZ public service. I identify which workers benefit from a premium and how the estimates change by using a number of multivariate analyses.

\subsection{Methodology Framework}

The focus of the research is on estimating the wage differential between collective and individual agreements. This study utilizes data from the State Services Commission's Human Resource Capability (HRC) Survey of 2005. This is the only available source in New Zealand of data on collective agreement coverage and union membership status of individuals. The HRC Survey contains wide-ranging individual level data on all public service department employees, as of June 30, 2005.

I used a range of statistical tests to examine the collective/individual wage differential. I first carry out basic comparisons of the average collective and individual wage across gender, employment type, occupations, ethnicity, age, employer size and tenure. This is followed by numerous multivariate regressions to estimate the impact of various contributing factors to the collective/individual wage differential. Finally, I analyze the results in the unique $\mathrm{NZ}$ context to allow new ideas and theory to emerge and compare these results to international trends.

A detailed description of the methodology framework is described in chapter 5 . 


\subsection{Research Question}

The principle question being addressed in this research is:

What are the pay differences between collective and individual agreements in New Zealand public service, in light of that sector's unique pay setting practices?

From the main research question, a number of secondary questions related to the nature of the collective/individual wage differential and the contributing factors to these differences are developed. These include the following:

\section{Nature of the collective/individual wage differential}

Is there a collective or individual premium in New Zealand public service?

What is the nature of the collective/individual pay gap, if there is a gap?

What is the size of the gap?

Nature of the contributing factors to the collective/individual wage differences

What factors/characteristics explain the gap?

What impact does each of those factors/characteristics - both as a set and separately have on the differential?

Defining the research questions permitted me to set the boundaries of the study and to center my research on a specific topic, as well as to make the most use of the data available and work within the data limitations.

\subsection{Outline of the thesis}

This thesis contains 7 following chapters plus 3 appendices.

Chapters $2 \& 3$ review the New Zealand public service context. These chapters present a broad overview of legislative and administrative changes in the public service in the 
context of broader legislative and administrative changes in NZ. They introduce the bargaining structure and unions' role in the public service in NZ. Chapter 2 summarizes the historical context, which very much sets the scene for the bargaining structure in operation in the public service at the present. Chapter 3 describes the remuneration systems adopted in the public service (using the Public Service Remuneration Systems: Principles and Practice survey published by the SSC in June 2005) to outline the main principles and practices used by the government departments to set the pay-fixing procedures. I also provide empirical evidence (using the Industrial Relations Centre (IRC)'s database) to support the findings of the survey and to enhance our understanding of the current remunerations systems in terms of union involvement in pay fixing procedures and its impact on union members' and their non-union counterparts' wages. A detailed description of the IRC database is found in the methodology chapter (chapter 5).

Chapter 4 covers the literature available on union/non-union differentials and the factors found to this influence phenomenon. I review international studies, across private and public sectors, and public service (a part of public sector that contains government departments only), across a large number of countries (mainly, UK, US, Canada, Australia and NZ) over a long period of time. I identify a wide range of contributing factors that are later measured in the analyses for this study. Finally, I examine the relevance to this study of the literature on the NZ public service bargaining structure and its outcomes. This literature review is used to: 1) contribute to the understanding of the impact of collective bargaining and unionism on wages, in particular how union/non-union wage differentials (if they exist) can be explained and are affected; 2) identify the variables that might contribute to these differences; and 3) compare the results of this study to previously conducted research to explain the phenomenon.

In Chapter 5, I explore the methodological underpinning of the research. I describe my logic in selecting a quantitative research perspective. Next, I describe the dataset used for this study and the limitations of the data.

Chapter 6 presents the results of simple crosstabulations (raw gap) of the average collective and individual wage across gender, employment type, occupations, ethnicity, age, employer size and tenure. I then provide the results of the multiple regression analyses. 
In Chapter 7, I draw out several broad conclusions and assess the extent to which the study has achieved what I set out to do in this research. First, the chapter examines the findings of this study against other research summarized in the literature review chapter. This is followed by a discussion of the findings and their implications in the wider context of the labour market experience of NZ in general and in the public service in particular.

Chapter 8 suggests areas for future research by further exploring the limitations of the methodology and dataset described in chapter 5. Finally, tables and references are in the attached appendixes. 


\section{Employment legislation context}

\subsection{Introduction to the Chapter}

Before moving on to estimating the collective/individual wage gap, it is appropriate to place these results in the wider context of the changes in the labor market experience of $\mathrm{NZ}$, in general, and public service, in particular. This section reviews the New Zealand public service context. The chapter presents the historical underpinning of NZ current public service pay-setting regime. A broad overview of legislative and administrative changes in the public service in the context of broader legislative and administrative changes in $\mathrm{NZ}$ is described. The historical context very much sets the scene for the bargaining structure in operation in the public service at the present.

\subsection{Prior State Sector Act - 1988}

From 1856, ministers had control of their own departments, and salaries and wages set by governments (Boston et al., 1996). In the years between 1890 and 1912, the Liberal Government significantly expanded the role of the state in the society and economy and, correspondingly, the number of government departments and employees. The Hunt Public Service Commission was established to report on recommendations for change; however, prior to when reports could be made, the Liberal Government was replaced by the Reform Party Government, which quickly introduced the Public Service Act 1912. The Act set the basis for the modern public service up to 1988 (Boston et al., 1996). The Public Service Commissioner was given authority over all personnel and industrial matters: appointments, grading, promotions, suspensions, dismissals, and pay and conditions. Public servants were given priority rights of appointment to any position within the public service. Conditions of employment were set by senior and independent public servants rather than politicians. Pay-fixing became the most controversial part of the 1912 settlement. Moreover, public servants had no access to compulsory arbitration or bargaining rights with the Commissioner. A similar situation, euphemistically called "public begging", had appeared in the USA and Canada prior to the 1960s. 
Understandably, pressure grew from the NZ state sector unions for a different system of pay-fixing. Throughout the democratic world, the Labour Government accepted, however unenthusiastically, the need for a change by enacting the Government Services Tribunal Act in 1948. The Act required that pay in the state sector be governed by a set of principles and criteria. The main principle was that pay and employment conditions in the public sector should be fairly comparable with those existing in the private sector. That was based on the state's need to employ and maintain the appropriate number and level of staff and to reward those staff on some equitable basis. This was to be achieved by either comparing state employees with comparable employees in the private sector or, where no direct outside comparison was available, pay was to be fixed by comparison with other groups within the state services, preferably those who were themselves linked to the private sector (Labour and Employment Gazette, August 1964; PSA report, 2004; Boston et al., 1996).

These rules limited government's ability to implement sufficient power over the determination of employment conditions in the public sector, which made both Governments (National and Labour) unhappy. By accepting the fair - relativity system, the government effectively imported outcomes of the private sector arbitration system into the public sector. These pay levels were set by a far less regulated process than that which had applied prior to the change. Furthermore, union membership levels grew in the public sector; unions became more confident and efficient, which led to a rise in industrial militancy. Every tool, political and industrial, was used to pursue the same pay levels that drove the unregulated private sector. Unions also took advantage of the system to secure non-remuneration benefits (such as leave entitlements) that were substantially superior to those in the private sector. This era, from the end of the World War II through to the late 1950s was notable for the increasing influence of the Public Service Association in personnel management (pay fixing) in the state sector.

In 1987, the Labour Government introduced the Labour Relations Act to direct bargaining in all sectors to the level of enterprise. This was to be achieved by the principle that any set of workers could be covered by only a single set of negotiations. The public sector came under the provisions of the law regulating industrial relations in the private sector. A Labour Court was introduced to resolve disputes of rights while the Arbitration Court focused on disputes of interest. Union monopolies were removed and 
unions could opt out of awards. In the public service, despite the new bargaining structure, job categories were standardized across the service, and pay and conditions applying to them varied little from one department to another.

To summarize, pay fixing procedures changed between 1912 and 1988, and they were perennially controversial. Following the 1912 Act, pay-fixing remained subject to political influence despite being formally under the control of the Public Service Commissioner. Prior to the Government Service Tribunal Act 1948, public sector unions, unlike their private sector counterparts had no bargaining rights and no access to compulsory arbitration (Boston et al, 1996). The 1948 Act established a pay-fixing system based upon equality relative to the private sector, gained, if need be, through compulsory arbitration by an independent tribunal (Walsh, 1991b). The basic structure of pay-fixing remained from 1948 to the 1980s (Powell, 1989). It was not until the State Sector Act 1988 that employment practices in public service were placed on a comparable level to the private sector.

\subsection{The State Sector Act 1988}

Prior to the State Sector Act 1988, employment relations in the public service were controlled from the centre. The State Services Commission (SSC) acted as the Government's central employing agency of the public service staff, negotiating and monitoring their employment conditions. Public sector unions were strong and had enjoyed high levels of membership. The process of decentralization in the public service began in the mid to late 1980s. Management positions had been removed from collective bargaining coverage and fixed term contracts were introduced to establish employment conditions. Under the State Sector Act, state sector unions became, for the first time, registered trade unions in line with the union registration provisions of the LRA. Registered unions enjoyed the exclusive right to represent the group or groups of workers, defined in the union's membership rules in negotiations for an award or agreement (Walsh, Harbridge \& Crawford, 2001).

With the introduction of the State Sector Act (SSA) 1988, which brought the state under the same regime as private sector workers (i.e. Labour Relations Act 1987) and the 
passage of the Employment Relations Act (ECA) 1991, a new era of state pay fixing was brought into being. The State Sector Act precipitated the organization the public service, bringing with it major changes to industrial relations and wage-fixing arrangements. It changed the relationship between Ministers and Heads of Departments. Permanent Heads of government departments were replaced by Chief Executives, appointed on a limited term contract with the possibility of renewal up to 5 years. It was the end of the unified public service. Chief Executives were made employers of their staff and were thus responsible for pay-fixing and conditions of employment (Boston et al., 1996).

Union membership had always been voluntary in the State Sector. Even though the SSA allowed for a compulsory unionism, the majority of unions decided to retain voluntary membership, giving faith in their members and their reasons for joining in the first place. In fact, membership levels remained very high.

The single most important industrial relations change associated with (but not directly caused by) the State Sector Act, though, was to the structure of bargaining in the public service. A shift to departmental bargaining had, in fact, been agreed by the SSC and the Public Service Association (PSA), the union representing State Sector employees, shortly prior to the SSA. It reflected the Unions' awareness that issues facing members were department specific and the employers' concern for more flexible and decentralized bargaining units. Nevertheless, while the structure of bargaining arrangements has changed, the process of bargaining itself remained highly centralized (Boston et al., 1996). As such, the new decentralized system still generates fairly uniform bargaining outcomes (including pay). For this matter, it is difficult to see how similar organizations operating in similar environments and labor markets and under similar pressures could do otherwise.

Following the SSA, departments, independent organizations, moved from the traditional service-wide determination system to one of individual national departmental collective agreements, ignoring geographical, divisional or occupational diversity. Ranges of rates, in place of salary scales, were introduced to respond to occupational and regional labor market situations. In some cases, if more than one union had coverage (members), more than one collective employment contract (CEC) was negotiated. Previously, employees at all levels were covered by collective agreements. But, now, the argument was that senior management, as the employer's representative, should not be involved (i.e., 
covered by a collective agreement), even indirectly, in negotiating an agreement in which they had a personal interest.

The SSC was driven to exclude senior staff in all sectors from the collective bargaining coverage and to shift them on to individual employment contracts. Moreover, individual contracts were valued in their own right as contributing to the development of a new management culture and as enhancing accountability (Boston et al., 1996). In return for industrial democracy and union facilities in most departmental agreements, the PSA agreed to senior officials being placed on individual contracts. Progressively, this was also extended down to the third level of management and was broadened to include staff with any involvement, as employer representatives, in the negotiating process.

The other significant development in the public sector was the growth of limited-term employment contracts. This indirectly resulted from a continuous restructuring process, which encouraged departments to appoint staff as needed for specific projects on a short-term basis. These public servants were employed on individual contracts. The occurrence of such contracts was never large, however it created an impression out of proportion to their frequency, and it helped foster the notion that traditional concepts of lifetime service and public service loyalty were fast disappearing.

The rule of "equal pay for equal work", which was introduced under the Government Service Equal Pay Act 1960, was potentially compromised, leaving the decision at the hands of employer, which was based on skills, level of education, experience, and other personal attributes of a candidate. Unions' goal was to maintain the living standards of their members, to build a more effective union representation and to strengthen already negotiated conditions of employment. Unions were consulted in the process, but the ultimate decision on terms and working conditions was reached by the management. To summarize, from 1988 to 1991, the negotiation of employment conditions (including pay) throughout the state sector remained under tight SSC control (Walsh, 1993b). In the public service, collective bargaining was shaped by the key role played by the SSC as an employer party. The Labour Government established a special Cabinet SubCommittee on State Wages, which was continued by the National Government following the election in 1990, to lay down policy for state sector employment negotiations and to oversee this process. 
The SSC's role as an employer party for the negotiation of employment conditions was seen as a contradiction of the decentralizing philosophy behind the State Sector Act and the Labor Relations Act. Public service departments often had very limited industrial relations experience and the Government wanted to ensure that inexperienced negotiators did not jeopardize its fiscal stance. The degree of direct control exerted by the SSC, nevertheless, varied across departments. The SSC's assessment was based on a number of factors, including industrial relations expertise within departments, their size and the likelihood of industrial action.

Each year, the SSC and the PSA would begin negotiations in a number of departments. The negotiations would continue despite deadlock, adjournments, and threats of industrial action until a settlement was reached in one department. That settlement would quickly become the standard and be disseminated throughout all public service departments. There was some flexibility on particular conditions of employment, which could vary to some degree from one department to another. Nevertheless, the new process of pattern bargaining instigated an outcome not so dissimilar from the centralized and uniform system of the past.

Pay outcomes in public sector collective bargaining were below those achieved in the private sector in this period. Both Labour and National Governments were determined to send to public servants at all levels a message that annual budgets would no longer finance unwisely negotiated wage increases and that their tight fiscal stance set severe limits to pay increases. Conspicuously, however, this was not the case at senior levels (employed on IECs), where salaries moved ahead very quickly and substantially. Priory to the SSC Act, negotiations had been conducted on the basis of existing conditions from which advances would be made by unions and employees. But, an attempt to 'claw back' on previously negotiated conditions or reverse past gains was a reflection of the new regime and its managerial emphasis (Boston et al., 1996). The elimination of compulsory arbitration made such a policy feasible for the first time. Since it could no longer be undermined by an arbitrated settlement, this policy was remarkably successful. 


\subsection{Employment Contracts Act 1991}

The same provisions of the ECA applied in the state sector to the same extent as in the private sector. The Employment Contracts Act 1991 showed an explicit preference for individual agreements over collective bargaining to establish conditions of work. In addition, collective bargaining was no longer the exclusive domain of unions. This resulted in a drop in the number of union members in both the private and public sectors. Furthermore, where a union-negotiated collective contract was in place, employers tended to extend the same conditions to non-union employees, making freeriding common practice (Harbridge and Honeybone, 1996; Anderson, 1991; Dannin, 1997) in the public sector as well as in the private sector. In the public sector, unions were returned to the situation that had applied prior to the State Sector Act 1988. That is, public sector unions were no different than any other non-trading body corporate. (Walsh et al., 2001). Employees could choose a negotiating representative; this might be a union, a lawyer, a consultant or anyone else (Kelsey, 1997-1998). The power of the PSA, a large and diverse organization, in the public service was weakened by the gradual desertion of dissatisfied groups in favor of other unions, alternative bargaining agents, or self-representation by members who decided to act on their own behalf. The Employment Contracts Act broke the automatic link between trade union membership and representation and created the potential for state sector unions to be challenged as the dominant bargaining parties in that sector.

The Act prohibited discrimination on the grounds of membership or non membership of a union, although, union membership was voluntary and employees could authorize any bargaining agent to negotiate individual or collective contracts (Walsh et al., 2001; Kelsey, 1997-1998). A 1996 survey of PSA members showed that 20 percent of the members joined for cost-benefit reasons only, not because they believed in unions or wanted to be part of a collective. However, members who believed in unions and were committed to union principles still amounted to 45 percent of the PSA's members. The outbreak of industrial action across the state sector in 1996 reflected the strong commitment of many rank and file workers to direct action, despite the more conservative and managerial approach of the union executive (Kelsey, 1997-1998). 
Notwithstanding these changes, the membership levels of state sector unions did not fall greatly. The main reasons for this include the small number of employers, the wellestablished tradition of voluntary membership, the large size (by NZ standards) of a high proportion of state sector workplaces, and the cooperative focus of unions on professional and employment issues (Boston et al., 1996). According to one estimate, overall trade union membership in NZ fell by 30 percent from December 1991 to December 1995, whereas unions in the public service lost only 13 percentage points in that time (Crawford et al, 1995).

As it was imposed by the SSA and reinforced by the ECA, senior and managerial public servants were pressured by their employers to leave collective agreements in favour of individual agreements, which minimized the collective power of those agreements and sets up a scenario for differential outcomes by grouping Throughout the State Sector, there were a handful of individual employees below managerial level who were exercising the option to be employed on individual contracts, often at the annoyance of senior management. The former preferred to have them on standardized agreements and, as a rule, their employment conditions did not vary from those offered on collective agreements. Moreover, for those employees, as well as for those who were employed on individual employment contracts (IEC) as a temporary solution, due to their collectives having expired, their employment conditions were effectively determined by collective rather than individual bargaining.

The 1991 Act provided a supportive environment for a number of the industrial changes that began to occur under the 1988 Act. For one, a gap grew between the more senior, highly skilled or specialized public service and those in lower paid occupations, a gap highly detrimental to women, as they were more likely to occupy the lower paid positions (Boston et al., 1996).

Nonetheless, while the whole public sector faced serious wage declines, public service only lost 1.4 percent. This reflects the fact that, there was a big difference between collective and individual contracts. Moreover, since 1991, the bargaining structure has substantially changed in NZ. In the public service, CEs gained negotiating authority with SSC maintaining close interest in employment conditions. There was little variation across departmental collective contracts in terms of core non-wage conditions of employment (i.e. various forms of leave, allowances and expenses), with pay 
increases being mainly determined through individual bargaining. However, the pre-Act bargaining structure of a single national departmental agreement has remained. The shift from a unified service to each CE acting as an employer of staff has been the most important source of diversity. In addition to that, the move from a bargaining system based almost completely on collective bargaining to one that combines individual and collective employment contracts and mixes standard permanent employment with fixedterm contracts and other non-standard arrangements, including the use of external contractors and consultants was another source of diversity. Moreover, as a result of individual agreements' growth, unions in the public service suffered a substantial loss of influence over managerial employment conditions (Boston et. al, 1996). However, the extent of this diversity should not be overestimated. The non-remuneration conditions of employment still tend to be the same across individual and collective contracts, as is to be expected given similar labour market conditions. The PSA was not involved in the negotiation of individual agreements, but was able to provide consulting services to help employees to negotiate their individual agreements.

The objectives of the ECA clearly indicated that the previous Act no longer offered a useful structure for the employment relationship. It also made it clear that there would be no return to compulsory unionism, national awards, and compulsory arbitration (Fosterand McAndrew, 2003). In the public service, in most cases and for the first time, management had the opportunity to communicate and develop a direct bargaining relationship with their staff and to build a sense of commitment and organizational loyalty. As a result, unions faced difficulties remaining relevant in the workplace. In this context, establishment of a range of rates became a double-edged sword for unions. They proved to be the vehicle for increased wages for many union members in a period where wage rates themselves were static, but this meant that pay increases were achieved on the basis of performance assessments of some kind. In the state sector, the structure established under the SSA 1988 and the ECA 1991 facilitated an aggressive approach by employers which had a negative impact on unions and their power (i.e., the ability to negotiate competitive employment conditions, including pay). Yet, the main threat to the role of unions in the public sector does not come less from a direct management assault than from an erosion of unions standing with their members as a consequence of their inability to be deliver improved working conditions. What did work in unions' favour was that, following high rates of unemployment, many 
employees still felt insecure and there was, hence, a perceived need for unions as a means of defense against prevailing market forces.

\subsection{Employment Relations Act 2000}

The new government (Labour) quickly set about implementing a set of significant reforms, particularly in the area of employment arrangements.

It is in the area of collective bargaining that the Employment Relations Act (ERA) 2000 has its most obvious impact on employment relationships. The ERA gives unions a monopoly over collective bargaining, promotes the concept of "good faith" bargaining and supports multi-employer bargaining. Employees may agree to be bound by either a collective or individual employment agreement, although they must be union members to be bound by the former. Free- riding ${ }^{1}$ is unlawful, and employees who are covered by a collective agreement must belong to a union. The Act also sets specific terms and conditions of individual agreement if employee is a union member.

Whilst some important changes have been made to bargaining parameters in the broader labor market, these have made little practical difference to the entrenched culture of bargaining that exists in the public service. The provisions of the ERA apply equally to all sectors, however the public service is also subject to the State Sector Act 1988 and other governing legislation. In particular, the role of the State Service Commissioner and the "good employer" and Equal Employment Opportunities (EEO) obligations of state sector employers remain unchanged from the specifications in the State Sector Act 1988. Hence, whereas the ERA introduced provisions that make new bargaining structures possible, particularly MECAs (multi-employer collective agreements).

Despite this and the fact that the PSA recognizes the value of centralized bargaining, the public service retained its decentralized bargaining structure. More to the point,

\footnotetext{
1 'In the labor union context, a free rider is an employee who pays no union dues or agency shop fees, but nonetheless receives the same benefits of union representation as dues-payers'.

(http://en.wikipedia.org/wiki/Free rider_problem). In December 2004, "the Act was amended to address the undermining of collective bargaining or collective agreements by employers who automatically pass on collectively bargained terms and conditions to employees not covered by that collective bargaining or agreement".
} 
decisions on whether to undertake multi-employer bargaining depend not only on the legislative means to affect bargaining in a multi-employer basis, but also on the attitude of employers and whether they support the strengthening of union organization in the current competitive economic environment (May and Lonti, 2003). 


\section{Bargaining structure}

\subsection{Introduction to the Chapter}

This chapter follows the previous one by introducing the bargaining structure and unions' role in the public service in NZ. I then describe the remuneration systems adopted in the public service, using the public service remuneration systems survey published by the SSC in June 2005 to underline the main principles and practices used within the government departments to set pay. I also provide empirical evidence from the IRC database to support the findings of the survey and to deepen the knowledge of these remunerations systems in terms of union involvement in pay fixing procedures and its impact on union members' and their non-union counterparts' wages.

\subsection{Public service}

New Zealand's public service is characterized today by single-employer bargaining. Each department has full control over the determination of wages and other conditions of its employees and is given very clear criteria in regards to what factors to consider when setting wages. These factors relate only to the individual department and include the ability to address organizational outcomes, pay within current baselines, recruitment and retention issues, and comparisons with others within the department. Any managerial coordination of bargaining between departments that exists is via the requirement of the SSC to be involved in being informed about the planning and progress of bargaining. Bargaining parameters set out deliberately to prevent departments from setting standards or executing proposals that have a likelihood of "flow-on". It is through this particular effect that unions have an opportunity to improve minimum standards and improve wages and conditions for their members within departments. Departments are advised by the SSC to alter pay to their own specific needs. To help Chief Executives follow the advice, their performance is measured, among other criteria, by their ability to meet their department's financial goals. At the same time, unions take advantage of the situation created by the competitive economic environment to negotiate more favorable pay and conditions than they would in a 
centralized bargaining structure (May and Lonti, 2003; PSA report, 2004, SSC survey, 2005).

The historical context very much sets the scene for the bargaining structure in operation in the public service at present. The ERA brought the public sector bargaining strategy in line with the NZ political and industrial environment. Several Government policies have seen a move to more collective bargaining. However, data collected by the SSC shows that around 46 percent of public servants are currently employed on individual agreements, with 58 percent belonging to a union, meaning that some employees retain their union status despite their or their employer's preference to negotiate individual employment agreements. For those members who are employed on individual agreements, the PSA provides a consultancy service to assist them in the negotiation of their agreements or the resolution of disputes arising out of them. Those employees remain members mainly because of their belief in the union movement and the union's importance as a political agent more than a bargaining agent (from interviews with PSA and public service officials).

The number of public servants employed on collectives has risen from 17 percent in 1994 to 49 percent in 2005 (SSC Annual Report, 2005). Twenty-eight government departments are currently party to collective agreements, whereas 7 departments are on individual agreements exclusively. For this latter group of departments, unions play no role whatsoever in setting of pay and other working conditions. These departments are small and employ only 2 percent of all staff in the public service.

Eleven departments have between 60 and 75 percent on collective agreements. These departments are mostly large and employ 62 percent of all government personnel. Hence, given that the majority of staff is collectively covered in these departments, it would be reasonable to assume that those collective agreements set the terms and conditions of the non-unionized equivalent staff in the departments. Even though the latest legislation sets implicit rules about collectively bargained terms and conditions to employees who are not union members, in practice, it does not prevent the employer offering other employees the same terms as those in collective agreements (www.ers.dol.govt.nz). 
The Public Service Association (PSA) is the traditional representative of public service employees in New Zealand. Seventy-six percent of union members belong to the PSA, making PSA the largest union in the public service. A small proportion of employees are members of other unions, e.g. National Union of Public Employees (NUPE), New Zealand's Finance sector union (Finsec), New Zealand Educational Institute (NZEI), Taxpro $^{2}$ and Central Amalgamated Workers Union (CAWU).

The general movement in public service pay has been slow compared to other sectors in recent years. In one year to June 2005, the public service showed an increase of $1.5 \%$ compared to $2.5 \%$ increase in the private sector. During the year to June 2005 , the average annual pay increases for the permanent employees in the public service was 5.7\% (SSC Annual Report, 2005), and the movement was not uniform: some didn't receive any pay increase and some received lump sum performance payments, which did not affect pay rates. This has led to recruitment difficulties, skill shortages and skill gaps. However, as noted earlier, it is not the same situation for all occupations.

Employers tend to offer higher salaries to senior, high skilled or specialized employees to attract and maintain them in the public service positions.

\subsection{Pay setting in the public service}

Bargaining over remuneration is central to the traditional activity of unions. The PSA's approach to remuneration requires that the union actively pursue it as an issue for collective negotiation and agreement, and that is done within the bargaining strategies and principled approaches and policies of the union. The Government expects that minimum pay rates will be a matter of negotiation in the collective agreement.

The bargaining structures in the public service have enhanced management discretion and lessened employee involvement through their union. However, public service remuneration systems were designed, in part, to have mechanisms that incorporate and encourage employee and union involvement. Despite the emphasis on departmental remuneration systems that led to the removal of pay from collective agreements in a

\footnotetext{
${ }^{2}$ Taxpro Inc. was established to represented employees of the Inland Revenue Department (those who did not belong to any other union)
} 
large number of government departments, unions retained their involvement in pay settings through remuneration systems. Overall, unions involved in the design, review, and/or adjustment of departmental remuneration systems. For the majority of departments (over 80 percent) the union is involved in the remuneration system as a part of the adjustment to pay ranges. Thirty six percent of departments have an administrative requirement in place to have union agreement on the range adjustments. Finally, around 30 percent of departments include the review of pay scales as a part of collective bargaining, whereas for the remaining departments the review of pay scales happens outside of the collective bargaining. In some but not in all cases, systems that include some aspect of review or design as part of bargaining also require union agreement on the same aspect. Note, that 7 departments out of 35 are not engaged in collective bargaining and do not have a collective agreement (SSC report, 2005).

Data collected by the SSC show that 40,325 people were employed in the public service at 30 June 2005. Fifty-four percent were on collective agreements (current and expired) and 58 percent of employees were union members. Under the Employment Relations Act, it is mandatory to include a clause defining the salary, wage rates or method of payment. The majority of the collective agreements mentioned above contain a mix of discrete wage rates, such as steps, and ranges of rates (i.e., a minimum and a maximum figure are specified and actual rates are determined through collective bargaining within this range). The remaining collectives do not contain wage clauses; instead, they only make references to ranges of pay rates. These references include links to general remuneration systems that covered employees outside the specific collective agreement. These are examples of a standard clause:

"A grade will be established for the job, which requires the job to be evaluated, and assessed by comparing it with other jobs in the department and in the market" - DIA remuneration system

"The Ministry will establish remuneration ranges for similar jobs in the Ministry, using information from job evaluation, market survey, the case on difficulty of recruitment and retention, and the ministry's ability to pay. The 
remuneration paid to an employee within the remuneration range established for the job will depend on performance."

“All positions are assigned a salary step within bars using the MQM Hay Job evaluation system.”

Remuneration is comprised of "a base salary, performance pay, other cash payments, and benefits such as superannuation or the provision of a vehicle." (SSC, 2005)

The main features of these remuneration systems are to encourage employee and union involvement, to determine internal and external relativities and to recognize the development of individual capacity, such as skills, knowledge and competence. They also aim to produce equitable outcomes for all employees (equity). In practice, the system is adaptable and able to deal with (some) differences in individual circumstances and/or changes in the internal and external environment, among other criteria.

Twenty-eight out of 35 public service departments responded to the SSC survey in 2005 on remuneration systems. Thirty-eight different remunerations systems were found. The vast majority of the responded departments had one system in place; however some operate with two, three or even four different systems. A number of reasons were identified for a department to adopt a certain remuneration system. Among others, the most common were to reward high performance ( $34 \%$ of systems) and to ensure relativity with the market/best practice $(26 \%)$. Job size is the main design principle underpinning the remuneration systems; competencies, performance or a mix of those criteria were also used in the design.

Although there are departments (70\%) where remuneration discussions are outside the collective agreement, unions are involved in a very powerful consultative forum. For some other departments, however, the consultative forum involves informing the union of decisions over remuneration, rather than offering any genuine engagement.

Sixty-six percent (25 departments) reported on having some form of union involvement. Sixty-eight percent (17) of these included the union in the system design, while 80 percent (20) involved a union to be a part of the adjustments of pay. Finally, thirty-six 
percent (9) of the systems included an administrative requirement to have union agreement on the range/scale adjustment.

Forty percent (10) agreed to include review of the remuneration system as part of the collective bargaining, 28 percent (7) included design and another 28 percent (7) included review of the pay ranges/scale as part of the collective bargaining. It should be noted, though, that four out of the 28 government departments that participated in the survey did not have a collective agreement in place. Also, for three of the 38 remuneration systems, salary ranges were used for general staff roles, but not for the management roles also covered by the system.

A system groups salaries into a series of ranges or bands, with job size ${ }^{3}$ as the criterion for assigning jobs to ranges. In most cases, pay ranges were not specified in the collective agreement and, in the handful of systems that did, not all ranges were specified.

In summary, the current bargaining structure reinforces the structure of bargaining that developed during the era of the SSA and the ECA by, among other things, departments being advised by SSC to alter remuneration systems to their own specific needs and circumstances. Departments are driven by the need to achieve corporate objectives, to improve staff performance and to develop staff. Moreover, departments are required to keep pay within current baselines. Despite the removal of legislative obligation to maintain relativity with the private sector, in practice, it remains important to CEs to match the private sector 'rate' in order to be able to recruit and retain able staff. In addition, CEs should not favor remuneration systems which "allow salary progression for time spent in the job," and choosing performance, competency, and relativities (internal and market) to determine pay progression.

Under the ECA, the PSA was forced to reach a compromise with the National-led Government in order to survive. This resulted in the removal of pay from the majority (approximately 70 percent) of collective agreements negotiated between the PSA and the Chief Executives. Where pay settings remained a component of collective bargaining, the union often was compelled to accept a reduction in pay in order to protect the jobs of its members. Ranges of rates and performance pay were introduced

\footnotetext{
${ }^{3}$ Job size points cover the level of knowledge, skills and accountabilities required to do different jobs.
} 
to forsake unionism. Despite all that, union membership levels remained high in the public service simply because public servants believed they have to speak up for the public through collective voice, even if there was a price to pay.

The ERA brought pay setting back to the bargaining table. By 2005, only 30 percent of the collective agreements negotiated between the PSA and CEs excluded pay from collective agreements. However, while the legislation has changed, the legacy of the previous bargaining structure, with links to employer-dominated remuneration systems, remains basically intact. Unions still have some form of involvement in and impact of the public service remuneration systems.

Also, the extent of diversity in pay outcomes should not be overstated. Central government employees (i.e., public service) still enjoy broadly similar conditions of employment, as should be expected due to similar labour market factors, collective culture that has been long standing and union-based collective bargaining remains vitally important.

The ERA curtails the ability of employers to extend collective agreement coverage to non-union members. This is not to suggest that free riding is not occurring. Especially where union density is high, it is likely that the provision of negotiated collective agreements will extend to similar employees who are not unionized. Moreover, where there are skill shortages, such as in the NZ public service, the union rate is likely to have a strong influence on the pay and conditions employers with non-unionized employees would need to offer in order to attract staff. 


\section{Literature review}

\subsection{Introduction to the Chapter}

This section covers the literature available on the union/non-union differentials and the factors contributing to this phenomenon. Within this section, I review the international studies, across private and public sector, and public service when available, across a large number of countries (mainly, UK, US, Canada, Australia and NZ, when available) over a long period of time. I identify a wide-range of contributing factors that later used in the analyses for this study. Finally, I examine the relevance of the literature to the NZ public service bargaining structure and its outcomes. This literature review is used to:

1) contribute to the understanding of the impact of collective bargaining and unionism on wages, in particular how union/non-union wage differential (if exist) can be explained and are affected; 2) identify the variables that might contribute to these differences; and 3) compare the results of this study to previously conducted research to explain the phenomenon.

Wage bargaining has been identified elsewhere as a primary function of unions. It follows that the union/non-union wage differential is considered an important measure of union power (Layard and Nickell, 1985; 1986). There is also an enormous body of empirical research internationally on the union/non-union wage differential, using both micro- and macro-economic models, demonstrating that union members receive higher wages than their non-union counterparts. At the same time, though, it is known that unions also have a considerable impact on the employment conditions of many nonunionized workers as well. To summarize the findings from this body of research, one could say it is well established that the "union wage premium" accrues to union members as well as to non-members in some labour markets (Flanders, 1970; Freeman \& Medoff, 1984; Mellow, 1981; Blanchflower \& Freeman, 1992; Kornfeld, 1993; Miller \& Mulvey, 1994, 1996; Miller, Mulvey \& Neo, 1999; Wooden, 2001b; Peetz, 2001; Belman \& Voos, 2004).

Numerous theories have been offered to explain this phenomenon. Lewis (1963) identified two effects of unionization on the wages of non-union workers. The first is a "spillover effect", where higher union wages compel unionized employers to cut their 
levels of employment, hence creating higher levels of unemployment and downward pressure on non-union wages (Lewis, 1963; 1990; Farber, 2005). Colbjornsen and Kalleberg (1988) conducted research in the Scandinavian countries, which are characterized by high levels of unionization (Neumann et al., 1991) but, at the same time, the economic advantage of belonging to a union seems to be particularly small (Le Grand, 1989). In their study, they explained this by occurrence of substantial spillover effects. With a high degree of unionization, unions have a strong influence on wage determination in the entire economy, and non-unionized employees are generally offered the union bargained rates. They also argued that standardization of wage rates across occupations is common. Moreover, wage settlements obtained by a union influence subsequent wage changes for non-unionized employees or employees belonging to other unions. Therefore, if spillover and standardization effects are sufficiently strong, lower union-nonunion differences are expected.

The second means by which unions can affect non-union wages that Lewis identified is the "threat effect", which results from a desire by non-union employers to avoid unionization by providing higher wages to their workers (Rosen, 1969; Pencavel, 1972; Lazear, 1983; Podgursky, 1986). To this end, Belman and Voos (1993) confirmed that non-union workers in more unionised markets earn higher wages, meaning that employers are willing to raise non-union employees' wages to discourage unionization. Farber (2005) presents an analysis of the threat effects of unions in the private sector, and he finds some evidence that wages of non-union employees are positively affected by the threat of union organization. A union's relative bargaining power is greater where the union has a larger share of workers as members. Union workers may earn more where legislation makes unions stronger and more secure. Slightly paradoxically, non-union workers may earn more as non-union employers attempt to forestall union organization (Mastekaasa, 1993).

Likewise, Card (1991) found that if a strong core of workplaces was unionized, nonunion employers would frequently meet union standards, or at least improve their compensation and labor practices beyond what they would have provided if there was no union presence. In other words, unions often play a significant role in improving minimum standards for all employees by setting a pay standard that non-union employers often follow. Based on his analysis of union/non-union wage differentials in 
Australia, between 1993 - 2001, Waddoups (2005) claims this is particularly the case where there are skill shortages. That is, in tight labor markets, the union rate is more likely to have a strong influence on pay and other employment conditions employers with non-unionized employees would need to offer in order to attract staff. Findings such as these point to the conclusion that the "threat effect" typically dominates over the "spillover effect", especially in highly unionized markets where the demand for skilled workers is likewise high.

Other studies have also identified labor demand and unemployment as important influences on the union/non-union differential. Blanchflower (1997) and Blanchflower and Oswald (1994) argued that, when unemployment is low (high), union wage premia appear to be low (high). This research also suggests that the union wage differential is positively correlated with the unemployment rate. This is because union wages are less responsive to change in the unemployment rate than non-union wages. Blanchflower and Bryson (2004), who updated Freeman and Medoff's earlier 1984 study, found that, in the US, variation in industry-level union wage premia remained; that state-level union premia varied less than occupation and industry-level premia. They stated that when there is strong labour demand, workers tend to organize less and there is less need for using union power to negotiate higher wages. However, where there are unfavourable working conditions, covered workers might be able to get higher wages, at the same time creating unemployment or worse working conditions for non-covered employees. Therefore, we should expect wider gaps between union and non-union wages when unemployment is high. Public sector wage premia also remained substantial and its magnitude was similar to those in the private sector. They also pointed out that collective agreements are longer term than individual contracts resulting in union wages responding to economic changes with a lag.

In New Zealand, however, there are employees who are union members but who are not covered by collective agreements, contrary to the more common occurrence in other countries (e.g., USA and Canada). Therefore, in New Zealand, the differential should be more precisely called the "collective versus individual" wage differential. In this regard, Peetz (2001) finds that Australian employees on collective agreements often experience inferior terms and conditions to employees on individual contracts, in fact having a "non-union premium". He argues that, employers may offer employees a higher wage 
through individual bargaining for the same type of work, in order to induce employees to forsake union coverage - "threat effect".

The union/non-union differential is yet to be calculated in New Zealand. Most of the literature that has been reviewed for this study has concentrated on union wage effects in other countries and mainly in the private sector, since most studies have examined the union/non-union wage differential in the private sector. However, only few such studies looked at the public sector and public service, in particular. Given the growing importance of the public sector's unionism, more studies are expected to be done in the future.

Studies of the public sector generally focus on the differences in the union-nonunion wage differential between the public and private sectors. Hansen (1998), for instance, found that the union advantage was larger for private sector employees than for those in the public sector. The union wage differential is large enough in most industries to encourage workers towards organization, and benefits under union contracts are generally superior to benefit packages for non-union workers. Schwenk (1996) found a decline in the union/non-union wage differential and the difference of occupational composition of union and non-union workers is one of the factors contributing to that outcome. White-collar workers are more likely to be non-union and blue-collar workers are more likely to be unionized. For one, in most countries, white-collar unions are quite a recent phenomenon, whereas blue-collar unions have been around for a much longer period. Therefore, blue-collar unions have had much more time to build their strength and to influence wage levels.

Some studies include the effects of unions and union bargaining power as explanatory variables for the public/private wage differential. Smith (1977), focusing on the US, reported significant positive union wage premium for both males and females employed by local government and for females employed by state government. Male state government and all federal government employees failed to earn a significant union wage premium. Blanchflower and Bryson (2004) found small differences in union wage gaps for nonwhites compared to whites in both private and public sector in US. They also argued that, wage gaps in the public sector are higher for women for than for men.

There seems to be a consensus in the US and Canadian public/private sector wage differential literature that the union differential is lower in the public sector, and more 
specifically in central government, than in the private sector (Freeman and Medoff, 1984; Robinson and Tomes, 1984; Simpson, 1985; Moore and Raisian, 1987; Gyourko and Tracy, 1988; Robinson, 1995 and Bender, 1998). Kornfield's (1993) study of Australian union wage premiums also found that the union premium exists primarily in the private sector, and he concludes that unions in Australia tend to raise wages more or less equally for all employees in the public sector. Gunderson et al (2000), after controlling for other determinants of wages, estimated that Canadian public sector employees covered by collective agreements earn 8 percent more than those not covered, which is in the range of the average union impact in Canada's public sector. These researchers found that wages rise consistently with establishment size: being 19 percent higher in establishment of 500 and more, compared to establishments of fewer than 20. Hence, they identified establishment size as a significant factor to the unionnonunion differential. They also found that there is a higher degree of unionization in the public sector than in the private sector and that, in general, unions tend to increase wages for all workers.

Regardless of a few issues with applying private sector methodologies to public sector data, Belman, Heywood and Lund (1997), in their study on earnings and the extent of unionization in the public sector in US, confirmed that the scope and structure of private sector unionization may be a determinant of public sector wages, as well as of public sector unionization and public sector bargaining structure. Similarly, Blanchflower and Bryson (2004) argued that most of the public sector experience and, more precisely, pay setting procedures follow the private sector. Farber (2005), though, distinguished between the organizational structures that unions operate under in the private and public sector in US, stating that unions operate in a very decentralized environment in the private sector, but not, for the most part, in the public sector.

As I mentioned in the previous chapter, in the New Zealand public service, the bargaining structure, since the 1991, has been highly decentralized, with bargaining taking place on a department-by-department basis. With the bargaining being delegated to departments, it is now managed by departments in accordance with the bargaining parameters issued by the Government. The state sector relies on the same guidelines to develop pay setting procedures as the private sector. Therefore, a summary of studies in 
the private sector is essential to the complete discussion of the union/non-union wage differential in the New Zealand public service.

Upon closer inspection of the public and private sectors in other national contexts, the majority of studies conclude that unions tend to negotiate higher wages for their members. However, some studies show that non-union members earn more than their union counterparts. Further to this, Freeman and Medoff (1984), in their seminal book 'What do unions do?',, claim that unions do not raise the wages of all workers by the same percentage. They argued that the union wage effect in the US differs significantly among workers, depending on their demographic characteristics and the occupation and industry in which they are employed. Nevertheless, in general, unions do not only raise wages for their members, but they also hold policies that require employers to provide "equal pay for equal work". This typically requires management to ignore skill differences across individuals and apply standard rate across all workers. Pay equity policies are most prevalent in the public sector. By equalizing pay, unions' policies raise the pay of otherwise lower-paid (less skilled) workers more than otherwise higher-paid workers. Accordingly, one expects larger union/non-union differentials for lower paid demographic groups.

Comparing workers' wages by age, tenure, occupation, industry, race, sex, and firm size, Freeman and Medoff found that the union wage effect is the largest for the youngest workers, who are typically the lowest paid, and the least for prime-aged workers, who are typically the highest paid. A similar pattern was found by tenure, with the union/non-union wage differential being the largest for those with the least amount of service, who are again among of the lowest paid. By race, the union wage effect is larger for non-whites than for whites. Also a strong correlation has been recognized between tenure, race and age. For employees with the least amount of service, nonwhites and young people, unions are able to negotiate higher gains. Further, the research cited by Freeman and Medoff identified that even though males already earn more than females due to other factors (e.g., experience and job tenure), unions raise male wages more than female wages, even after holding constant these other effects. Focusing on occupation, the authors note that unions typically win larger gains for blue-collar than for white-collar workers. At the same time, union wage differentials fall with firm-level 
vs. industry-level agreements (e.g., suggesting a negative effect of decentralized bargaining) and size of the work site.

Lewis (1986) concluded that, for men and women, the estimates were the same size. Mulvey (1986), in his study of unionism in Australia, emphasizes the differential impact of gender on the union/non-union wage differential. He found that male union members received 9.6 percent higher wages than their non-union counterparts, while female members received 7.4 per cent higher wages. The union wage effects also varied according to personal and job characteristics, occupation and industry. More highly educated, male, non-union workers, for example, received higher wages than their union equivalents, effectively creating a negative union differential.

Cristie (1992) identified occupational status as one of the explanatory variables behind the union wage premium in Australia. Peetz (2001), in his comparison of individual contracts and collective bargaining in Australia, determined that many employees on individual contracts are senior managerial and other senior staff. Consequently, many employees on individual contracts have high earnings because of their occupational position, and this distorts any comparison between workers on individual contracts and other workers. Occupational status, level of seniority (manager, worker) and gender are highly correlated. Senior or managerial employees are likely to be highly educated males on individual agreements and therefore earn more than their union equivalents.

Hansen (1998), among others, reported that union membership and the union/non-union earnings ratio was greater among men than women and higher among blacks than either whites or Hispanics. Workers aged 35 to 64 are more likely to be members of unions than either younger or older individuals. Full-time workers are more than twice likely to be union members than part-timers. He points out that geographic and other demographic differences may account for part of the gap. To this end, analyzing data for union members in similar jobs and with equal job experience and similar demographic characteristics showed that, union members earn more than their nonunion counterparts.

Hirsch and Macpherson (2001), examining changes in union wage effects by industry, found evidence that union members earn more even after statistically holding constant years of schooling, years of potential experience and its square, marital status, race, 
gender, part-time work, region, broad industry and broad occupation. Examining union wages and union membership in the private sector in the US, they found that average hourly earnings for union members are higher than for those who are not members. Part of the difference they explained by different stocks of human capital or skills, on the part of the two populations. Another part reflects different opportunities related to labour market location and the personal characteristics of employees. However, even after controlling for numerous observed wage-related worker attributes, economists typically find that union workers earn more.

An almost universal finding of the literature is that union/non-union wage differentials are larger for lower skilled than for higher-skilled workers (Johnson \& Youmans, 1971; Ashenfelter, 1978; Freeman, 1980, 1982; Lewis, 1986; Card, 1996; Mishel \& Walters 2003). Freeman (1980) has argued that unions standardize wages by decreasing differentials across and within job positions, so that low-skilled workers receive a large premium relative to their alternative non-union wage (Freeman 1980, 1982). Lewis (1986) provides a survey, concluding that union wage gaps decrease with occupational skill level and schooling (pp.128-31, 136-39). Card's (1991) research showed that in the US unions raise wages more at the bottom and in the middle of the wage scale than at the top and that the union wage premium was far greater among low-wage workers than among middle or the highest wage workers.

In his later studies, using longitudinal analysis from a 1987/88 CPS panel of male workers, Card (1996), in his comparison across all sectors, arrives at the conclusion that all worker OLS wage level and longitudinal union/non-union wage differential estimates are similar, and that there exists positive selection among workers with lower measured skill and negative selection among those with higher measured skill. He also concludes that long-term union wage effects decline with skill level. Following these arguments, Mishel and Walters (2003) have pointed out that unions raise wages more for low and middle wage workers than for higher wage workers, more for blue-collar than for white-collar workers, and more for workers who have less than a college degree.

Hirsh and Shumacher (1998), conducting longitudinal analysis using 1989/90-1994/95 CPS across skill groups, have provided a careful examination of union wage effects and skills using longitudinal analysis from a 1989/90-1994/95 CPS matched panels. In 
contrast to Card, the authors concluded that union wage effects are remarkably similar across workers with different measured levels of skills. Their results cast some doubt on the thesis that unions both seek and acquire larger proportional wage gains for low-skill members rather than for high-skill members.

There is a considerable body of econometric evidence concerning the relationship between union wages and union membership. In industries in which a larger percent of the workforce is organized, union workers have been found to earn more relative to non-union workers (Belman and Voos, 1993). Hirsch (2004) argued that, in the public sector, density is much higher than in private sector. However, Freeman and Medoff (1984) claimed that union density does not have any impact on union workers, implying that union/non-union wage differential grows with the percentage of the industry that is organized.

Wooden (2000) has also shown that, in Australia, strong union presence -where the majority of workers are covered by collective agreements - confers a wage advantage in the order of 15 to 17 percent, which applies to members and non-members alike. In contrast, union wage effects are small and insignificant at workplaces where collective agreements have not been negotiated. Peetz (2001:437) has pointed that, in voluntarist regimes, collective bargaining is strengthened when union density is higher; but while it is possible in many regimes to have union members who are not covered by collective bargaining, in such circumstances unions are largely ineffective in achieving gains for their members.

In more recent research, Waddoups (2005) suggested that, where union density is high, it is likely that the provisions of negotiated collective agreements will extend to similar non-unionized employees. In his findings, both union membership and union density have an impact on the wages and of all workers, both union and non-union. Workers receive a premium for union membership, though, and the union premium is higher in a high-density industry.

Blanchflower and Bryson (2004) suggest that the relationship between union density and union wages depends on the level of density. They argue that a strong effect is achieved when density is higher than 40 percent. Other research indicates that falling union density in the US over the period from 1979 to 1996 has been accompanied by a 
decline in the union wage premium (Belman and Voos 2004). These findings not withstanding, Card (2001) suggests that, in spite of falling union density in the US, union/non-union wage differentials covering the period from 1973 to 1993 have been largely unchanged (Card, 2001).

Although research has established that unionized workers in industrialized countries generally enjoy higher wages than their non-union counterparts, the magnitude of union wage premium varies from country to country, as well as across sectors, demographic groups, periods of time. There is a wide range of estimates for Australia, varying between 3-18 percent (Cristie, 1992; Kornfeld, 1993; Miller \& Mulvey, 1994, 1996; Miller, Mulvey \& Neo, 1999). The most recent study puts the union/non-union net wage differential between 1-6 percent (Wooden 2001), using various assumptions for union activities.Park (1991) estimated, in South Korea, a differential of 4.2 percent for men and 5 percent for women. Wagner (1991) found, in Germany, significant positive union effects for blue-collar workers. Schmidt (1995) found a significant wage differential of just under 6 percent. Neither Schmidt nor Schmidt and Zimmermann (1991) were able to find evidence of significant union wage gaps for men in Germany. For Sweden, Le Grand (1989) reports a union/non-union difference of only 2 percent, whereas Kalleberg and Colbjornsen (1989) found a 16 percent difference in their Swedish data. The net union wage premium in the US has been estimated in the range of 15-20 percent (Hirsch \& Schumacher, 2001; Blanchflower \& Bryson, 2004). In the UK, the net union wage premium amounted to around 5 percent (Metcalf et.al, 2001). In Canada, most recent estimates put the gross union wage differential at 14 percent and the adjusted differential at 7 percent (Fang and Verma, 2002).

\subsection{New Zealand public service context}

As mentioned prior, due to data constraints in NZ, the union wage premium is yet to be calculated for the NZ public service. However, Blanchflower (1996), in his report on the role of trade unions in the United States compared to eighteen other OECD countries using micro-data at the level of the individual, presented an estimated union wage gap for New Zealand's labour market as a whole at 8.4 percent. In the same study, it was also found that unions do much better within centralized as opposed to 
decentralized wage setting systems. In a centralized system, the same rules apply to all workplaces, highly unionized or low unionized, with a shift to a single bargaining the rules have changed. As it is described in details in the previous chapter, NZ public service today operates in a very decentralized environment, which weakens the role of unions in the bargaining system and pay-fixing procedures in particular.

\subsection{Outlines of the literature review}

Relative to the large number of empirical studies that have been done on the wage differential, the theoretical area is rather undeveloped. In fact, none of the studies reviewed here offers any formal theoretical model or explanation why the wage gap between private and public sectors exists. Most decomposition studies attribute the differential between different levels of personal and job characteristics, industry and firm related features.

Moore and Raisian (1991) propose other reasons for the differential. The first is the theory of compensating differentials. However, they discount this explanation, since public sector workers tend to get better wages and fringe benefits than their private sectors counterparts. They also discuss the proposition that the premia are due to skill differentials which, in the long run, should be (according to neoclassical economic theory) the only reason for wage differentials. Fogel and Lewin (1974), by examining the US Government, conclude that the government uses the highest wages since they must offer the higher wage to attract workers who would otherwise choose a private sector job (i.e., a compensating differential). Also, the lower end occupations might receive higher wages if it is government policy to increase wages of low skilled individuals (e.g., pay equity policies).

In summary, the literature shows that in most instances union workers receive higher pay than comparable non-union workers; however, there is considerable diversity in union wage-gap estimates across individuals, sectors and bargaining structures. The following factors have been identified in contributing to the size of union/non-union wage differential: union density (the proportion of workers in an industry who report union membership), collective bargaining coverage, size of establishment, age, gender, 
industry, occupation, education, region, term of agreement, ethnicity, marital status, tenure with current employer and in a given occupation, and demand for labour.

The following factors, out of all the identified contributing factors in the literature are used in this study: Size of establishment, age, gender, occupation, region, term of agreement, ethnicity, and tenure with current employer.

Due to data constrains, the remaining factors are not included in the analyses. The implications of this omission are detailed in the methodology chapter (chapter 5). 


\section{Methodology framework}

\subsection{Introduction to the Chapter}

Within this chapter, I begin by describing the methodology utilized, followed by detailed illustration of the dataset used for this study, limitations of the data, variables included in the analyses and some notes to assist with the interpretation.

\subsection{Methodology}

The SPSS 12 version was used for the data analysis. Cross tabulation tests were completed to compare the average collective and individual wage across all available employee and employer related characteristics. I used OLS analyses to estimate the union/non-union wage differential, using the natural log of the full-time equivalent $\left(\mathrm{FTE}^{4}\right)$ salary as a dependent variable while controlling for the same employee and employer related characteristics used in cross tabulation analyses.

Some researchers use the gross wage difference (i.e., means comparison) between union and nonunion workers. However, these do not provide a true picture of the differences between comparable workers within comparable workplaces - thus the need to adjust the gross wage differential by controlling for other factors known to influence wages, such as gender, age, ethnicity, occupation, term of employment, hours of work, the union the employees belong to, tenure and the size of the employer ${ }^{5}$. A dummy variable for type of employment agreement is specified in regressions. This measure reflects two categories: individual (between an employee and the employer) or collective agreement (between multiple employees and one employer as parties). Employees on current and expired collective agreements were aggregated into one category; this was allowed due to the fact that, although an agreement has come to an end, employees remain under the same terms and conditions till a new agreement is negotiated. A single coefficient, then, gives an estimate of the collective/individual differential in wages, controlling for observed employee and workplace characteristics.

\footnotetext{
${ }^{4}$ Annual full-time base salary (\$) as at June, 2005

${ }^{5}$ The full set of variables and definitions are included in Appendix (1)
} 


\subsection{Data source}

This study focuses on identifying the differences in wages that are contained within individual and collective agreements in the New Zealand public service.

For this study, I have used data that mainly comes from the 30 June 2005 Human Resource Capability (HRC) data collections for the State Services Commission, which gathers anonymous unit record data on all staff in 35 government departments. The core government departments are defined in the State Sector Act 1988. While the survey includes all permanent and temporary employees, as well as part-time employees, it excludes contractors, Chief Executives and employees employed on a casual or asrequired basis.

The variables included in the analysis are those variables contained within the HRC datasets. Each observation is a unique public service employee, adding up to 40,290 observations in total. Descriptive statistics are reported in Appendix (2). The data are used to estimate the extent to which collective bargaining might effectively set pay terms and conditions for workers on collectives and individual agreements in the public service.

The Industrial Relations Centre (IRC) database was used in this study to support the findings of the SSC survey on public service remuneration systems and to deepen the knowledge of the current remunerations systems in terms of union involvement in pay fixing procedures and its impact on union members and their non-union counterparts' wages. For the past 14 years, the Industrial Relations Centre at Victoria University has surveyed NZ employers and trade unions and requested a copy of each employment contract/agreement that has been collectively negotiated. Expired agreements are replaced with renegotiated agreements. In this manner, a longitudinal data series was established. These encompass the overwhelming majority of employees covered by collective agreements in New Zealand. In June 2005, the sample included a complete set of public service collective agreements. 


\subsection{Limitations of the data}

The SSC survey data, my primary source, have confidentiality protocols, and therefore, some of the variables (such as education or skill level, marital status etc.) were removed from the set. Also, some reporting such as organization size (bands), age (bands) and occupation $\left(2\right.$ digit level $\left.^{6}\right)$, are in aggregated form and individual departments were not identified in the dataset used for this study. Other contributing factors identified in the literature are simply not collected as part of the HRC report. These include union density (the proportion of workers in an organization who report union membership), collective bargaining coverage, education, marital status, and demand for labour. This leads to potential omitted variable bias, for example, the failure to adequately control for workplace factors that may influence wages (especially important in decentralized environment). Union density within an organization and the number of CEAs in place in each organization allows for determination of the extent of unionization at the level of which collective bargaining takes place.

Education appears in a large number of studies of the union/non-union wage differential as an important explanatory factor. However, there is also evidence that education is not an important determinant of earnings. Choudhury (1993), for instance, states that "the relative unimportance of education in explaining wages lends support to the screening hypothesis which states that education does not enhance one's ability but merely serves as a screening mechanism “(Choudhury, 1993). In addition, an employee's marital status was found to be positively related to unionism in other studies, indicating the importance of including it in the equation, if available (Booth and Bryan, 2004).

\subsection{Variables used in the analyses}

The dependent variable: The natural log of (FTE) annualized salary served as the dependent variable in the regression models. Reasons for that are stated below (refer to preliminary tests section). The salary information comes from the employing department and relates to the employee's annual base salary on the payroll system. This

\footnotetext{
${ }^{6} \mathrm{NZSCO}$ codes are presented in a form of: $1-5$ digit levels, with 5 digit level presenting most specific occupations.
} 
means that additional, "above base" earnings, such as performance pay, bonuses, overtime etc, are omitted from the annual salary figures for all employees.

The predictor variables: Measures of gender, age, ethnicity, occupation, term of employment, hours of work, the union the employees belong to, tenure and the size of the employer are also specified in the regression models.

All independent (predictor) variables were dichotomized to simplify the interpretation of the results.

Gap calculations: By NZ law, only union members can be covered by collective agreements, moreover, in practice, only a small portion of union members are employed on individual contracts. Therefore, in this context, it makes sense to compare salaries on collective agreements versus those on individual agreements. I expect the differential to be similar to union/non-union differential, since most unionised employees in NZ are on collective agreements and all non-union employees in $\mathrm{NZ}$ are on individual agreements.

I extracted the coefficient on the contract type variable, the coefficient on the contract type was then turned into a wage gap taking anti-logs, deducting 1 and multiplying by 100 to turn the figure into a percentage.

Model evaluating: Due to the large sample size, both R square and adjusted R square are the same values, therefore the adjusted R square values were reported for all models.

\subsection{Model fit}

I have used regression analysis to produce an equation that will predict a dependent variable using one or more independent variables. This equation has the form

- $\operatorname{Ln} Y=B 1 X 1+B 2 X 2+\ldots+A$

where $\operatorname{Ln} Y$ is the natural logarithm of the observed annual salary of an employee (salary), $X 1, X 2$ and so on are the independent variables that I am using to predict LnY; $b 1, b 2$ and so on are the predicted coefficients or multipliers that describe the size of the effect the independent variables are having on the dependent variable $Y$; and $A$ is the value $Y$ is predicted to have when all the independent variables are equal to zero. 
Multiple regression finds the set of estimated (estimates of Bn) that provides the best fit between the model and the given data.

Different studies use a wide-range of analyses, such as establishment- level analyses, cross-sectional estimates, producing estimates based on longitudinal data. Lewis (1986) and Freeman (1984) point out that cross-section and fixed effect estimates or "panel" estimates of the impact of unions on wages "bound the true impact unionism", whereas OLS estimates are less biased.

\subsection{Regression diagnostics}

Multivariate regression can appear as a fussy tool and is not appropriate for small samples where the distribution of scores is very skewed. However, there are also a number of other assumptions that should not be violated. These include collinearity, outliers, normality, linearity, homoscedastisticity, and independence of residuals diagnostics (Tabachnick and Fidell, 2001). A number of preliminary tests were performed prior to proceeding with the analyses. The given set of variables was tested for how well it is able to predict the outcome, which variable is the best predictor of the outcome, and whether a particular predictor is still able to predict the outcome when the effects of another variable is controlled for.

All regressions conducted for this study include a matrix of individual characteristics determining wages, a matrix of some of the workplace characteristics and a dummy variable equal to one if individual is covered by a collective and zero otherwise. Only one regression (\#1) includes both a dichotomous variable equal to one if employee is a union member and zero otherwise and the contract type dummy variable. Another regression replaces the contract type variable with the union membership variable. The equation contains individual variables assumed to influence human capital formation (including age, tenure within a department, ethnicity, occupation, hours worked, and contract term). It was argued by others that some of these variables are also likely to be related to membership status, and so are important controls (Booth and Bryan, 2004). Workplace characteristics, such as size and region, were also included in the equation. 
Regressions \# 4 also contains interaction terms with the contract type variable. Table 1 in Appendix 1 defines the variables.

\subsection{Preliminary data tests}

Information on the distribution of salaries was obtained (skewness and kurtosis). The skewness value provides an indication of the symmetry of the distribution. Kurtosis, on the other hand, provides information about the 'peakedness' of the distribution. Positive skewness values indicate positive skew (salaries clustered to the left at the low value). Positive kurtosis values indicate that the distribution is rather peaked (clustered at the centre), with long thin tails. However, since the sample is quite large, skewness will not 'make a substantive difference in the analysis (Tabachnick\&Fidell, 2001, p.74). Kurtosis can result in an underestimate of the variance, but again, this risk is also reduced due to the large sample (200+ cases: see Tabachnick \& Fidell, 2001, p.75).

I have also assessed the normality of the distribution of the salaries for both collective and individual agreements. I have calculated the 5 percent trimmed mean, to obtain this value I have removed the top and bottom 5 percent of my cases to recalculate the means and to determine whether or not the more extreme cases are having a strong influence on the mean. This was found not to be the case.

The test of normality showed a significant result $(\mathrm{p}<.001)$, where a significance value of more than .05 indicates normality. However, this result is quite common in larger samples. This does not necessarily indicate a problem, but simply points out that are some cases of employees earning higher salaries.

Homogeneity of variance (Levene test) was performed to test for equality of variances of two groups of employees, those employed on collective agreements and those on individual agreements (collective and individual). A significant value was obtained (1.19), which suggests that variances for the two groups are not equal, and therefore the assumption of homogeneity of variance is violated. Provided the size of both groups is reasonably similar (e.g. largest/smallest=1.5, Stevens, 1996, p. 249), though, analysis of variance is reasonably robust to violations of this assumption. 
Another major assumption refers to the relationship among the independent variables. Two values were examined for collinearity: tolerance and VIF. Tolerance is an indicator of how much of the variability of the specific independent is not explained by the other independent variables in the model. It is calculated using the formula 1-R (square) for each variable. If this value is less than .10 , it indicates a high correlation with other variables. The VIF (variance inflation factor) is the inverse of the tolerance value (1 divided by tolerance). VIF values above 10 would be a concern, indicating multicollinearity. Both values for all variables are high, indicating that the multicollinearity assumption was not violated. It is not surprising, given that the Pearson's correlation coefficients for the variables were not high.

Union membership and contract type value did not exceed those commonly used cut-off points, however the correlation coefficient is still quite high (0.7), therefore I had one of the highly intercorrelated independent variable removed from the analyses (Tabachnick and Fidell, 2001).

As described in detail in other sections, only union members in New Zealand's public service are covered by collective agreements; therefore it made sense to omit union membership from most of the analyses. Moreover, no major problems with the data or using these multiple regressions were identified. However, the set of data values is skewed to the right, indicating that regression diagnostics are worse when the untransformed salary variable is used. Accordingly, the transformed (natural log) of annualized salary (FTE) was taking value to result in a data set that is roughly symmetric and often roughly normal. The t-tools work best with symmetric, roughly normal populations. Thus, it is often better to analyze the natural logarithms of the data values rather than the raw data when the raw data are right skewed.

For most analyses, standard multiple regressions were used to estimate the collective/individual wage differential. The results are presented in the Appendix 2.

\subsection{Relationships between the variables}

Correlation tests were used to explore the nature and strength of relationships between the variables. The relationship between the variables was investigated using Pearson 
product-moment correlation coefficient. Table 3 in Appendix 2 summarizes these findings.

A significant relationship was found between the salary variable and each of the independent variables $(\mathrm{p}<0.01)$, indicating that each variable explains some percentage of the variance in employees' salary, although some of these correlations may be spurious. In addition, the size and the direction of the correlation vary across the variables. Different authors suggest different interpretations of the strength of these relationships. I followed Cohen's guidelines ${ }^{7}$ to determine the strength of the relationship. There was a medium-size negative correlation between salary and occupation: $(\mathrm{r}=-.424, \mathrm{n}=40,290, \mathrm{p}<0.01)$, meaning that occupation helps to explain 18 percent of the variance in employees wage rates. The contract type, organization size and union membership variables explain 8,6 and 5 percent of the variance in employees' wage rates, with $(\mathrm{r}=0.284, \mathrm{n}=40,290, \mathrm{p}<0.01, \mathrm{r}=0.241, \mathrm{n}=40,290, \mathrm{p}<$ 0.01 and $\mathrm{r}=0.231, \mathrm{n}=37,539, \mathrm{p}<0.01$ ), respectively. A similar size positive relationship between those variables indicates that salaries are higher on individual contracts and for non-union members. The larger the organization is, the higher the salary. Age and tenure each has a small positive correlation with the salary variable, implying that, salary increases as age and department tenure increases $(\mathrm{r}=.217, \mathrm{n}=$ $40,290, \mathrm{p}=0.01 ; \mathrm{r}=0.183, \mathrm{n}=40,290, \mathrm{p}<0.01)$.

Union membership and contract type were found to be highly correlated $(\mathrm{r}=0.8, \mathrm{n}=$ $23,281, \mathrm{p}<.0005)$, indicating that 64 percent of the variance in employees being on one contract type or the other is explained by them belonging to a union or not. Therefore, due to multicollinearity, I have removed the union membership dummy variable from any further analysis. Nevertheless, this result was expected, since in line with New Zealand legislation, only union members are covered by collective agreements and only a small portion of union members are on individual agreements.

It was also observed that the union membership status of an employee has very little effect on the strength of the relationship between contract type and salary in regressions including both the union membership and contract type dummy variables. In other words, even if an employee on individual agreement is a union member, due to his/her ideological beliefs towards unions, that belief does not affect his/her salary (tested by

${ }^{7} \mathrm{R}=(-\mathrm{or}+) .10$ to $.29-$ small; $\mathrm{r}=(-$ or +$) .30$ to $.49-$ medium; $\mathrm{r}=(-$ or +$) .50$ to $1-$ large 
partial correlation, controlling for union membership). In most industrial countries, coverage $^{8}$ and membership ${ }^{9}$ are less highly correlated because there is less pressure on employees to become members where there is a coverage agreement (Hildreth, 2000). In NZ it is a law that only union members get coverage.

Further examining the coefficients, it was also found that employees on collective agreements seem to have more experience, be employed as permanent staff, work in larger organizations, in blue-collar occupations and earn lower salaries than employees on individual agreements. Also, unionization seems to be positively related to employer size: the larger the employer, the higher the ratio of employees on collectives. There seems to be a strong correlation between age and being on collectives, as well as between tenure and unionization. This means that, the older a person is, the more likelihood he/she is on a collective. The same applies to tenure: the more tenure a person has, the more likely she/he would be unionized. All of these factors suggest that the negative simple correlation, between union membership (or contract coverage) and pay may be misleading, and that this relationship may be mitigated by some indirect effects through intervening variables.

Occupation is defined based on the New Zealand Standard Classification of Occupation at the two-digit level. The occupational composition of the public service differs markedly from the NZ labour market as a whole. Seventy-five percent of public servants are in the professional or clerical and administration occupation groups, compared with 31 percent in these groups for the labour market as a whole. All occupations that were employed in the NZPS at the time of the survey were included in the analyses, with some changes to the legislators, administrators and managers groups. These occupations contain two main groups of people: Chief Executives and diplomatic representatives. Due to confidentiality protocols and the fact that collective bargaining plays no role in their pay settings, Chief Executives have been removed from the data. Ethnic categories in the survey include: NZ Maori; NZ European; Pacific Islands; Asian, Non-NZ European, other ethnicity and unknown. Term of employment includes two categories: (1) fixed - limited (contract/agreement with a specified end date) and (2) open (permanent employee). Hours of work differentiates between full time employees who work more than 30 hours per week and part-time employees with less

\footnotetext{
${ }^{8}$ Employees who are covered by collective agreements

${ }^{9}$ Employees who are union members
} 
than 30 hours per week. Age, employer size and tenure are described in categories. Tenure is measured within a department. For age, a mid point was calculated for each category (band). Again, all variables on the right-hand side of these regressions are specified as dummy variables.

\subsection{Setting the scene}

In 2005, 21,878 (54\%) employees of the New Zealand public service were employed on collective agreements, compared to 18,412 (46\%) being employed on individual agreements. In line with the a priori expectations, the minimum wage rate for a full time employee on collective agreement is slightly higher ( $\$ 20,857$ per annum), compared to the minimum wage rate on individual agreement $(\$ 17,791$ per annum). However, looking at the maximum wage rate, it is the other way around: individual agreements offer much higher salary $(\$ 309,850)$ than do collective agreements $(\$ 182,000)$.

These findings are expected, since many employees on individual agreements are senior managerial and other senior staff; consequently, many employees on individual contracts have high earnings because of their occupational position. Also, it supports the hypothesis that unions improve minimum standards, creating larger gaps for lower income levels. Average collective agreement earnings for both full-time and part-time employees is $\$ 44,561$, compared to average individual agreement earnings of $\$ 57,971$, bringing the non-collective wage premium to 23 percent. This result was estimated by simple comparison of means, without controlling for differences in individual, job, workplace and regional characteristics. In addition, the income disparity on individual agreements is substantially larger than it is on collective agreements; once again, this difference can be attributed to occupations. Union members are likely to be labourers, associate professionals, clerks and trade workers (occupations that earn around the average salary) and less likely to be managers or professionals. 


\section{Findings}

\subsection{Introduction to the Chapter}

In this chapter, I first provide the descriptive statistics of the data. I then carry out basic comparisons of union/non-union wages by gender, employment type, occupation, ethnicity, age, employer size and tenure. These are followed by multivariate analyses of the dependent variable (salary) while controlling for gender, employment type, occupation, ethnicity, age, employer size and tenure.

\subsection{Research Purpose}

The union/non-union differential has been calculated many times before, by a great number of researchers, using a wide range of data sets across many countries. However, due to data limitations, the union premium not previously been calculated for the New Zealand public service. New Zealand State Services Commission's Human Resources Capability Survey (NZ SSC HRC) is the only available local source of individual level information on collective agreement coverage and union membership. This research seeks differences between collective and individual wages using the NZ SSC HRC. My aim is to 1) explore what variables contribute to pay differences between union and nonunion employees in the public service and 2) to evaluate the impact of employee' and employer' specific characteristics on the collective premium, if one exists.

In order to achieve these objectives, I 1) carry out basic comparisons of the average collective and individual wage by looking at the raw gaps across gender, employment type, occupations, ethnicity, age, employer size and tenure, 2) work out the contributing factors through a numerous sets of multivariate regressions, and 3) analyse the results in the unique NZ context to allow new ideas and theories to emerge and to compare them to international trends. 


\subsection{Dataset characteristics}

Table 1 in Appendix 1 contains the descriptives for all the variables used in this research. The full set contains 40,290 public servants. In this sample, 54 percent are employed on collective agreements while around 58 percent are union members. Public service is dominated by female employees (59\%). Asians is the smallest, however the fastest growing ethnic group of all (5\%), followed by Pacific Islanders (7\%). Maori represent 18 percent and 75 percent of core government employees identified themselves as NZ Europeans. The vast majority (90\%) of the workforce is permanent staff and work full-time. More than 84 percent of the public service employees are employed by large organizations with 1000 or more employees. The largest occupational group is associate professionals (36.6\%) followed by professionals (29.2\%). Clerks constitute 17.5 percent of the workforce, while corporate managers represent 9.7 percent. The bulk of the employees are in the 30-50 age group. Almost 21 percent of the workforce has less than 1 year of service (within the Department) and 28 percent has only 1 to 3 years of service. Thus, almost half of the public service employees have limited experience gained within an organization, while less than 30 percent has more than 10 years of service, indicating high staff turnover. Not surprisingly, a large percent of employees are based in Wellington (NZ capital) versus less than 1 percent being employed overseas (mainly diplomats). Virtually the same proportion of employees works in Auckland (20.3\%) as in the rest of the North Island $(22.5 \%)$ or the South Island (16.5\%).

\subsection{Unionization}

Slightly more women (55\%) are employed on collective agreements than men (53.2\%). Unionization seems to focus on permanent employees, as 58 percent of them are on collective agreements, compared to only 16 percent being fixed term employees. Union members are employed on both collective and individual agreements. Nearly 18 percent of union members are on individual agreements, with a large proportion of them belonging to Public Service Association, indicating that there is more to unions than just their ability to raise their members' economical conditions. Some people choose to be a union member out of their ideological beliefs in the role of unions, the importance of 
their existence and the impact they have on the society ${ }^{10}$, as well as using their membership as an "insurance policy". In the NZ public service, as discussed in chapter 2, senior management and other senior staff were pushed out of collective bargaining; however some of these employees retained their union membership under the SSA 1988.

Around 55 percent of full-time employees and nearly 51 percent of part-time employees are on collective agreements. The unionization rate for Pacific Islanders and Maori is 64 percent and 61 percent, respectively, followed by Asians and NZ Europeans with 55 percent and 53 percent, respectively. The former findings are remarkably similar to the overall unionization rate of the public service workforce (54\%). PSA is the largest union in the sector, representing 76 percent of union members, whereas slightly over 15 percent of them are hired on individual agreements. The remaining 3 percent of union members covered by individual agreements belong to a number of small occupationrelated unions that operate within the public service.

Looking at the various occupations, the "other workers" category which mainly contains tradespeople is most organized (74\%), followed by associated professionals (66\%) and clerical and administrative workers (64\%). As expected in the NZ context, corporate managers is the group with the least coverage, as one in five corporate mangers is on a collective, however nearly 40 percent of them are union members. This is still considered a high ratio considering the concentrated efforts by various governments to push corporate managers to individual contracts since the inception of state sector reforms in the late 1980s. Differences in unionization rates among the various occupational groups might also reflect a negative relationship between job responsibilities and being on a collective. Legislators and administrators is another group of workers with a low collective coverage, however the unionization rate is extremely high (75\%). Even though, due to data aggregation, there is no way of distinguishing between legislators and administrators; it is more likely that administrators would be the ones that are employed on collectives and not legislators.

\footnotetext{
${ }^{10}$ A full discussion on reasons for joining a union is beyond the scope of this study.
} 


\subsection{Analyses}

\section{Mean wages}

Table 2 in Appendix 2 reports the mean salaries and mean raw wage differentials between collective and individual agreements by gender, agreement term, union membership, hours of work, employer size, occupation, age, employer tenure and ethnicity.

On average, NZ public service employees on collective agreements earn 23 percent less than those employed on individual contracts. Positive collective premiums were found for workers under 20 years of age (8\%), teaching professionals (51.2\%), the lowest paid professional occupation, and "other workers" (labourers and trade people) (1.2\%). The highest wage differential was found for teaching professionals (51.2\%), the lowest earners out of all professionals, with 50 percent of them covered by collectives. Labourers and tradespeople are the lowest earners of all occupations, (1.2\%) with 74 percent of the employees covered by collective agreements. These findings are in line with the findings of a large body of previous research (Freeman and Medoff, 1984; Card, 1991; Mishel and Walters, 2003).

\section{Occupation}

Further, looking at the data by occupation, large negative differentials are shown for diplomats $(34 \%)$, corporate managers $(36 \%)$, followed by professionals: life science $\&$ health professionals (20\%), other professionals (15\%) and physical, mathematical \& engineering science professionals (13\%). Professionals are the largest occupational group in the NZ public service and are international dominated due to skill shortages. For these occupations, global market forces set the floor for public sector wages, since public sector employers must compete with the local private sector and, in some cases, international markets to attract highly qualified employees (Gunderson, 1978a and 1979). The associate professionals (4\%) and clerks (4\%) had modest negative union premiums. In the white-collar occupations, the size of the differential seems to be related to the level of responsibility required for the job. This is in line with the findings of Peetz (2001), who also found that, in Australia, employees on individual agreements earn more than those on collectives and linked this to occupational differences. Many 
previous studies have also shown larger union gains for blue-collar workers than for white-collar workers (Card, 1991; Mishel and Walters, 2003), and this is substantiated in the NZ public service as well. These findings seem to follow a large number of studies where the union/non-union wage differentials were found to be larger for lower skilled workers than for higher skilled workers. (Johnson and Youmans, 1971; Ashenfelter, 1978; Freeman, 1980; 1982; Lewis, 1986; Card, 1996; Mishel and Walters, 2003). The twist in the NZ public service results is that most lower-skilled employees on collectives still earn less than their counterparts on individual contracts, however the negative differential is smaller for the lower-skilled occupational groups than for the higher-skilled ones. At the same time, union density within an occupation group might also be related to the size of the union/non-union wage differentials by occupation, as labourers and trades people, associate professionals, and clerks are all highly unionized.

\section{$\underline{\text { Gender }}$}

In terms of gender, males on collective agreements earn 30 percent less than males on individual contracts, while for females, the negative union differential is smaller: at 17 percent. This is contrary to the findings of the literature, as usually unions provide greater gains for males, who already earn higher wages, than for females (Mulvey, 1986). However, traditionally, unions were male-dominant, and that would explain why other research found unions more effective in negotiating higher earnings for their male members. Some studies, nevertheless, have shown a positive union premium for females in the state and local government, failing to do so for males (Smith, 1977). Lewis (1986), for instance, concluded that, for men and women, the estimates were the same. At this stage, I can only speculate about the reasons for the significant difference in the differential by gender. One of the contributing factor might be the occupational composition across genders, with females congregating in lower paid occupations and males more typically holding more senior and managerial positions, which command higher salaries. At the same time, senior and/or managerial employees are more likely to be employed on individual agreements. I, further on, undertake multivariate analyses to either support or refute these findings. 


\section{Organization size}

Focusing on employer size, the smaller the organization is, the larger the negative union premium. Within organizations with less than 200 workers, employees on collective agreements earn 28 percent less than employees on individual agreements; virtually the same differentials were found for employees working in medium size (200-999) and big organizations (over 1000) $(-21.1 \%$ versus $-20.8 \%)$. This might be related to union representation, though, as smaller organizations have much lower union density than larger ones.

\section{$\underline{\text { Age and department tenure }}$}

Looking at the size of the differential by age, it has been established in the literature that the union wage effect is the largest for the youngest workers and the smallest for prime aged workers (Freeman and Medoff, 1984). The findings of this study are consistent with those results. Although a negative union wage differential exists for all age groups (except for employees younger than 20 years old), it is the smallest for those between 20 and 24 years old (2\%), steadily increasing till the age 55-59 group (32\%), and then slowly decreasing to a (-18\%) for the $65+$ age group. Tenure follows the same pattern, although the differences between the various groups are less pronounced: employees with less than one year of service on collectives earn (24\%) less than employees with longer than 10 years of service, who earn (34\%) less on collectives than on individual contracts.

\section{$\underline{\text { Term }}$}

In reference to term of agreements, employees in permanent positions who are employed collective agreements earn (26\%) less than their counterparts on individual agreements. In comparison, employees on fixed-term agreements, who are covered by collective agreements, earn (14\%) less than employees on collectives.

\section{$\underline{\text { Permanent and part-time workers }}$}

The gap also varies by hours worked. Part-time employees on individual agreements earn higher salaries than their counterparts on collective agreements, however, the differential is more moderate than for full time employees $(6.3 \%$ versus $24.6 \%)$. 


\section{$\underline{\text { Regional variation }}$}

Disregarding the "overseas and missing occupation" group, Wellington has the highest negative union wage differential (26\%). Three other regions also showed a wage gap in favour of non-covered workers; however the gaps are more moderate: Auckland (10\%), Rest of North Island (2\%) and South Island (8\%).

\section{Ethnicity}

Finally, by ethnicity, the literature review shows that the union/non-union earnings ratio was greater for blacks and Hispanics than for whites, indicating that unions provide more gains for groups that are traditionally disadvantaged in the labour market (Hansen, 1998). This study concurs with those findings, although there is still a negative collective premium for both Pakeha and Maori in the NZ public service. However, the gap is wider for all ethnic groups in this sample: Pacific Islanders, the most unionized ethnic group showed a smaller gap (9.1\%) than Maori (18\%), Asians (20\%), Non-NZ European (24\%), other ethnic groups (17\%), and Pakeha (25\%).

In summary, simple comparisons between the average salary earned on collective versus individual agreement across a wide range of contributing factors that were identified in the literature review estimated the raw collective/individual wage gap at (23\%). However, previous research has shown that the union wage gap can be partially explained by differences in personal, job and workplace characteristics. Therefore, I now turn to multivariate analyses to estimate the adjusted collective wage premium. This is done by controlling for most of the independent variables that were recognized in previous studies.

\subsection{Regressions results}

All regression results are presented in Appendix 3.

Although simple comparisons across all factors show a non-union premium, after controlling for numerous observed wage-related worker attributes, economists typically find that union workers earn more. 
Several variations of the standard regression model were used in this study to estimate the union/non-union wage differential, including adding interaction terms of each variable with the contract type variable. This involves all of the independent variables being entered into the equation at once to indicate how well this set of variables is able to predict pay levels; as well as to demonstrate how much unique variance each of the independent variables explains in the dependent variable, over and above the other independent variables included in the set ${ }^{11}$.

\section{$\underline{\text { Regression \#1: }}$}

Table 1summaries the results of the regression and the omitted category for each variable. In this regression, the union status dummy variable was included despite its high correlation with the contract type variable to confirm the decision for it to be omitted. Due to previously discussed reasons ${ }^{12}$, the same coefficients are expected for both variables.

\section{Evaluating the model:}

The model explains 58 percent of the variance in salaries $(\mathrm{R}$ square $=.580)$, with the model reaching statistical significance at the level of .000 .

The adjustments for personal and workplace characteristics substantially reduced the collective/individual wage gap, providing more reliable estimated differentials between comparable employees.

\section{Coefficients}

Employees on individual agreements earn slightly more than their counterparts on collective agreements, estimating the non-collective premium at 2.8 percent. At the same time, non-union members earnings are 1.7 percent higher compared to union members' earnings. The salaries for men are higher than for women by almost 3 percent.

\footnotetext{
${ }^{11}$ Detailed explanations on the regression models and variables included in the analyses are summarised in the methodology section.

12 Only union members are covered by collective agreements and a small portion of union members are employed on individual contracts, with their pay being determined by individual bargaining. Moreover, preliminary checks revealed that being a union member on an individual agreement did not have any impact on the employee's pay rate.
} 
Pacific Islanders earn the lowest salaries of all ethnic groups, while non-NZ Europeans earnthe highest salaries. NZ Europeans closely follow this group, which is also the largest ethnic group in the public service. The covered/not covered wage differential between Asians and Pacific Islanders is small (below 1\%), however it is significant at level of .004. The "unknown ethnicity"13 employees earn similar wages to Maori $(b=0.022$ and $b=0.20$, respectively, both significant at the level of less than $1 \%$ ) relative to Pacific Islanders.

Furthermore, analyzing the results by occupation portrays legislators and administrators, which contain a small number of individuals (75 employees - less than $1 \%$, with the union members placed at the lower end of the pay scale), earn at least $15 \%$ higher salaries than all other occupations. Corporate managers and all professionals (except for teaching professionals) earn from 5 to 15 percent higher salaries compared to the omitted category. All the rest of the occupational groups earn substantially less than the omitted category ("not specified"). All the results are significant at less than the 1 percent level.

Permanent employees earn over 5 percent higher salaries than their counterparts on fixed term agreements. However, most of the public service employees are employed on permanent agreements.

The results show that the wage rate increases with job tenure within the department. Compared to the most experienced employees (with over 10 years of experience within a department), employees with fewer years of service earn less. As expected, the largest gap was found among employees with less than one year of service $(6.3 \%)$, followed closely by employees with 2 years of experience (5.1\%). Employees with 3 or 4 years of experience are earning virtually the same salaries (slightly over $2 \%$ less than employees with over 10 years of tenure). All the results are significant at 1 percent alpha level.

The coefficients on the regional variables indicate that, relative to Wellington, salaries are lower in Auckland, followed by South Island and the rest of North Island (5.3\%, $6.4 \%$ and $6.7 \%$, respectively, at the significant level less than $1 \%$ ).

${ }^{13}$ Includes employees who identify themselves as "New Zealanders" 
Department size has a negative impact on wage rates. The smaller the size of the organization, the higher the wages are. Small (less than 200 employees) and medium sized departments (200 thru 999) offer 4 percent and 3 percent, respectively, more to their employees than large departments (with over 1000 employees), at a significant level of less than 1 percent.

Finally, full-timers earn almost 1.5 percent $(\mathrm{p}<$.0005) compared to their part-time counterparts.

\section{Regression \#2:}

In this regression, the union membership dummy variable was removed from the equation, due to its high correlation with the contract type dummy variable.

\section{Evaluating the model}

As in the previous model, this model explains nearly $58 \%$ of the variance in salaries, with the model reaching statistical significance at the level of less than 1 percent.

\section{Coefficients}

Omitting the union variable from the equation has increased the collective vs. individual wage differential by less than 1 percent to a negative 3.7 percent, whereas the rest of the coefficients remain the same. These findings support the fact that only union members are employed on collective agreements and that union members who are employed on individual agreements are placed at the lower end of the pay scale.

\section{$\underline{\text { Regression \#3: }}$}

To support my assumptions in the previous regression (\#2), the same exercise was performed with the contract type variable being replaced by the union variable.

\section{Evaluating the model}

This model explains nearly $58 \%$ of the variance in salaries, with the model reaching statistical significance at the level of less than 1 percent. 


\section{Coefficients}

Controlling for all the remaining variables, non-union members receive higher salaries than their union counterparts. The wage differential is estimated at 3.1 percent, remarkably similar to the estimate concluded in regression \#2, with the contract type variable (3.7\%). The rest of the coefficients remained the same.

\section{Regression \# 4:}

In my further analyses (regressions \#4 and \#5), I have adjusted the new premium against the premium estimated with a contract type dummy and controls for employee and employer characteristics by creating interaction terms of each independent variable with the contract type variable.

\section{Evaluating the model}

As a result, the model's ability to explain the gap in salaries on collective vs. individual agreements increased to nearly 62 percent, with the model reaching statistical significance at the level of less than 1 percent, indicating that a relationship existed between $\ln \_$salaries and all the predictor variables taken together.

\section{Coefficients}

The collective vs. individual coefficient is insignificant $(b=.021$, sig. $=.113)$, though, indicating that there is no difference between comparable employees on collective agreements and individual agreements. These findings confirm the expectation of no collective wage effect in the NZPS due to the fact that, despite the legislation forbidding free-riding, the terms and conditions of collective agreements are passed on to all employees, regardless of their union status. This study confirms the hypothesis that the collective wage effect is stronger for women than for men, for blue-collar than for white-collar employees.

In general, a few interaction terms' coefficients are insignificant.

Analyzing closely some of the interaction terms, part time employees benefit more from being on collective agreements than do full time employees $(b=-.023$, sig. $=.000)$. Permanent employees earn higher salaries than employees on fixed terms $(b=.008$, sig. 
$=.090)$. These groups are traditionally high earners. Moreover, compared to the most experienced employees, employees with less than 10 years of service gained a noncollective premium of between 1 percent and 3 percent. Also, large organizations are able to offer higher salaries to their employees on collectives than small organization (less than 200 employees $)(b=-.022$, sig. $=.013)$. In line with some of the previous findings, female benefit more by being on collective agreements than male $(b=-.020$, sig. $=.000)$.

Across occupations, the premium is highest $(b=.164$, sig. $=.000)$ among the traditionally low paid occupations within the public service sector. This is confirmed by teaching professionals earning significantly higher salaries on collective agreements than other occupations. There are small differences in collective wage gaps across all regions, with Wellington being an exception to that. Compared to the rest of NZ, the wage benefits of collectivism are greater for Auckland, the rest of North Island and South Island than Wellington $(4.3 \%, 5.3 \%$ and 5.7\%, respectively). Also, compared to Pacific Islanders, only NZ Europeans are in significant disadvantage by being covered by collective agreements $(b=-.013$, sig. $=.000)$.

The contract type*age interaction term coefficient shows that, relative to prime-aged employees (65 years old or older), there is a collective premium for younger (between 18 years old and 34 , inclusive) workers with the wage gap decreasing as the age increases (from $7 \%$ to $1 \%$, respectively). Also the level of significance of the results changes: 30 thru 34 years old $(b=.071$, sig. $=.000)$, and 35 thru $39(b=-.012$, sig. $=.057)$. The collective wage effect is the largest for the youngest workers, who are the lowest paid, and the least or negative for prime-aged workers, who are the highest paid. These findings are consistent with international literature. 


\section{$\underline{\text { Regression\#5 }}$}

Due to previously discussed reasons ${ }^{14}$, I have now omitted senior managerial and other senior staff occupations from the equation. These include: legislators and administrators, corporate managers and all other professionals.

\section{Evaluating the model}

The model explains nearly 55 percent of the variance in salaries on collective vs. individual agreements, with the model reaching statistical significance at the level of less than 1 percent.

\section{Coefficients}

After removing the mentioned above occupations, the coefficient on the contract type variable is now insignificant $(\mathrm{b}=-.009$, sig. $=.322)$, confirming that there is no wage differential between employees on collective vs. individual agreements.

Consequently, the gender coefficient has increased, reaching 5 percent in favour of male employees ( $\operatorname{sig} .=.000)$, and the contract type by gender variable reaches nearly 4 percent $(b=-.036$, sig. $=.000)$. The wage differential between large and small organizations turned out to be insignificant, however middle size (between 200-999) organizations are shown to be offering better pay conditions than larger organizations $(\mathrm{b}=.007$, sig. $=.051)$

In the following analysis, the collective agreement and individual agreement models were regressed separately in order to tests the impact of independent variables on each group.

Regression\#6: Split files by contract type variable:

For these analyses I have split the data by contract type and conducted the same tests for both sets, including the union membership variable. Since only union members are covered by collective agreements, the union variable was automatically excluded from the analyses of collective agreements.

\footnotetext{
${ }^{14}$ I.e. Skill shortage and rrecruitment sources (international and private market), pay settings through individual bargaining.
} 


\section{Evaluating the models}

Looking at the adjusted R square values, both models have good explanatory power, explaining 63.1 percent of the variance in ln_salaries for employees on individual agreements and 48.5 percent for employees covered by collective agreements. The Ftest in each of the ANOVA tests was statistically significant at p. $<.001$.

IEA model coefficients (major outcomes)

Concerning the union membership variable, being a union member and employed on individual agreement has very little impact, if at all, on wage rates $(b=-.004$, sig. $=.055)$.

Experience increases wage rates for those employees who are employed on individual agreements.

The wage differential for permanent vs. fixed term employees is larger (5\%), however at the significance of .097. On the other hand, part timers earn statistically significant higher salaries than full timers.

\section{CEA model coefficients (major outcomes)}

Examining the coefficients in the collective agreement model, I found that permanent employees receive higher salaries than fixed term employees $(b=.018$, sig. $=.000)$. Fulltimers earn slightly more than part-timers $(b=.011$, sig. $=.000)$. Employees in small organizations and who are employed on collectives earn more than employees on collectives that work in large organizations. However, organizational size does not make a statistical difference.

\section{CEA vs. IEA (major outcomes)}

High-skilled occupations (legislators and administrators, corporate managers, and some of the professional groups) are paid more than other occupations on both collective and individual agreements; however, the wage differential is larger for those employed on individual agreements than those on collectives. Compared to other professionals, teaching professionals are significantly disadvantaged under individual agreements. These findings are supported by the results from previous analyses. 
Wellingtonians earn more than public servants in other regions with overseas employees being an exception in both models. Being male increases the ability to earn more, on both agreements, individual and collective.

\subsection{Summary}

In this chapter, I presented the findings of the research. The first section included descriptive analyses of the variables included in the dataset, followed by simple comparisons of the average wage between collective and individual wage across gender, ethnicity, age, occupation, employment term, hours worked, tenure, organization size and region. The raw gap (23\%) indicated inferior pay conditions for employees on collective agreements across these factors. Collective premiums were found for younger workers, teaching professionals and labourers and tradespeople. Teaching professionals $(51.2 \%)$ seem to benefit the most from being on collectives; these are, not surprisingly, the lowest earners out of all professionals and highly unionized workers. These findings are in line with the findings of a large body of previous research (Freeman and Medoff, 1984; Card, 1991; Mishel and Walters, 2003).

I, then, presented the results from the multivariate analyses, where I compared wages between collective and individual agreements, while controlling for employee and some employer- related characteristics. My findings suggested that a number of factors influence the covered/non-covered wage gap. For instance, the occupation variable explains 24 percent of the variance in salary, highly-paid professionals and senior managerial staff played a particularly important role in shaping the nature of the gap. Finally, after controlling for all the available variables, the salary differences between collective and individual agreements were found insignificant. I found that, in most cases, my results comply with other studies described in chapter 4. I showed how my findings support or differ to the literature relating to the union/non-union wage differential and the factors that contribute to such gap. 


\section{Conclusions and implications}

\subsection{Introduction to the Chapter}

The purpose of this study was to provide a more integrated knowledge of a collective bargaining role in pay setting and its impact in the New Zealand public service by estimating a collective/individual pay differential while controlling for a large number of variables that were identified as explanatory factors in previous studies. To achieve this I have used numerous multivariate regressions. My goals were to determine: 1) whether or not such a gap exists; 2) the nature of it; and 3) who are the beneficial parties of the potential gap. The major implications and findings gained from the empirical research are discussed below.

In examining the collective/individual pay differential, and the factors that influence it, a number of important points emerged regarding the impact of collective bargaining on pay levels in the public service in New Zealand.

\subsection{Means comparison}

The raw collective vs. individual pay differential strongly suggests that covered employees receive inferior pay rates to those who are not covered by collective agreements. These differentials vary across gender, ethnicity, employer tenure, union membership, employer size, contract term, age, hours worked and occupational factors.

Although a vast majority of studies conclude that union members gain higher pay rates than their counterparts, this finding seem to reveal a different picture. This finding, however, supports the hypothesis that individual agreements are frequently used to avoid unionization. Government departments have the resources and sophistication to mount concerted union avoidance and use individual employment agreements (IEAs) to offer wage premiums to induce workers to signs individual agreements and/or financially penalize those who seek to remain on collective agreements (Peets, 2008).

The raw gap (23\%) indicated inferior pay conditions for employees on collective agreements across these factors. Collective premiums were found for younger workers, teaching professionals and labourers and tradespeople. Teaching professionals $(51.2 \%)$ 
seems to benefit the most from being on collectives. These workers are, not surprisingly, the lowest earners out of all professionals and highly unionized occupational group. These findings strongly support the findings of a large body of previous research (Freeman and Medoff, 1984; Card, 1991; Mishel and Walters, 2003).

\subsection{Multiple regressions}

Most economists point out that the contributing factors to the union/non-union pay differential could only be identified through multivariate analyses. The results of the multivariate regressions showed that when the contributing factors, including interaction terms are controlled for, no collective premium was found. This is a completely different picture to the one revealed by means comparison. Once again, it is not the same case for all employees. That is, the nature and the size of the collective/individual pay differential varies across employee and employer related characteristics. In general, the collective pay effect is the largest for the youngest workers, non - Europeans, who are the lowest paid, and the least or negative for primeaged workers, who are the highest paid. These findings are consistent with international literature. I offer a number of explanations for this phenomenon.

1) Although the free-riding issue has been addressed by the legislation in December 2004 , most of the agreements included in the sample of this study were negotiated prior to legislative changes. Also, despite the local regulation forbidding free-riding, the terms and conditions of collective agreements are passed on to all employees disregarding their union status. This is usually done in agreement with a union. What union members get in return is backdated pay. After all, it would be hard to do otherwise, given that all departments operate in the same labour marker conditions and are out to achieve similar goals that are set by the same governing body.

2) Decentralized bargaining system - As was described in chapter 3, the NZ public service operates in a very decentralized bargaining system, where bargaining occurs at the departmental level. In such an environment the role of a union is relatively weaken and unions are less able to negotiate the same outcomes as they would have done in a more centralized system. Although multi-employer bargaining is promoted by the legislation and the PSA recognizes the benefits of it, the system remains highly 
decentralized, indicating that no support for centralized multi-employer bargaining has been shown from management. The SSC has delegated its responsibilities of employer to Chief Executives of each department, and it seems that it intends to keep it this way. The shift towards enterprise bargaining thus made the emergence of sizable union wage differentials across different enterprises a distinct possibility.

3) Although unions and collective bargaining have been promoted by the government and the appropriate legislation in the public service, union involvement in the paysetting process is limited. Also, employees in managerial positions are discouraged/pushed off collective agreements, thus increasing the pay gap between management and the rest of the public service. Managers are expected to perform in a way that departmental objectives will be achieved and to set pay levels within set baselines. This leads to a conclusion that unions are limited in their influence and ability to obtain better gains for their members and contributes to the explanation of the nonexistent collective premium. On the other hand, even where unions do have greater say in determining pay, they tend to standardize wage rates for union and nonunion members.

4) Skill shortage is one of the main issues that government departments are looking to address. Occupational composition was found by a number of economists as one the most important explanatory variable to the union/non-union wage differential (Freeman and Medoff, 1984, Mulvey, 1986, Cristie, 1992, Peetz, 2001). These results support this hypothesis. Some of the differential can be explained by the fact that, high pay-levels are highly correlated with the recruitment source of these employees. NZ public service has a unique structure in the way that it relies quite heavily on professionals. This group is internationally dominated (with the exception of teaching professionals) due to high levels of skill shortage in NZ, meaning that a percentage of these employees come with international experience, and therefore are in high demand and are able to negotiate higher salaries through individual bargaining. Employers are "forced" to offer higher than average salaries to be able to attract those talented candidates to the public service.

In contrast, union members and employees covered by collectives are usually employees with a lower length of service (within a Department), working their way up within a department or across departments and are New Zealanders. These employees earn lower salaries than their "imported" counterparts. 
5) Level of education would be another explanation for those differences. Nevertheless, due to data constraints, the education or skill level variables were not available for this study. 


\section{Areas for Further Research}

\subsection{Introduction to the Chapter}

This chapter proposes areas for further research provided by the limitations of the dataset and the methodology used in this study (a detailed summary of those is provided in chapter 5). The results highlight several important insights and constructs that are may need further research. First of all, when compared to broader international studies, that use a wide range of methods to estimate the union/non-union wage differential, as well as different type of datasets, more work needs to be done to test the generalisability of the findings in other settings, datasets and statistical approaches if they are actually fair representatives of the collective/individual pay estimates in the NZ public service unique context.

Second, although my dataset contains a large number of employee-employer related characteristics, I can not claim to have a comprehensive set of the collective/individual pay gap contributing factors. I compared salaries between collective and individual agreements across ethnicity, age, gender, employment term, occupation, tenure, hours worked, organization size and region. Yet, due to data constraints, I ignored other explanatory factors that were identified in previous studies. For instance, education, training, and marital status were found by other researchers (e.g., Booth and Bryan, 2004) as being union membership related and therefore important controls. In addition, Wooden (2001) argued that datasets should enable differences across bargaining units, especially in decentralized bargaining environment to produce true estimates. This can be achieved by including coverage by enterprise agreements and identifying workplaces with agreements compared to those without them, though neither of these pieces of information was provided to me. A better test of the impact of unions on wages, especially in an environment where enterprise-level bargaining is pervasive, requires data on wages and characteristics of individual workers that can then be linked to characteristics of the firm and workplaces at which they are employed. Most important of all, data are required on the features of union and bargaining activity at those workplaces. Measures of degree of union coverage or activity within the bargaining group to which the individual belongs (Booth, 1995) should also be included to provide better estimates of the collective bargaining impact on wages. 
Furthermore, measures of the context specifics are also important, such as labor demand, unemployment rates and union density, offer interesting avenues for future research.

Finally, no panel data was available; therefore time series analyses could not be conducted, leaving an area for further research. 


\section{References}

Addison, J. T., Siebert, W. S. (August 2002). Changes in collective bargaining in the U.K., Institute for the Study of Labor: 1-57.

Addison, J. T., Bailey, R., Siebert, W. S. (February 2003). The impact of deunionisation on earnings dispersion revisited, Institute for the Study of Labor: 1-28.

Anderson, G. (1991). The Employment Contracts Act 1991: an employers' charter. New Journal of Industrial Relations 16: 127-142.

Ashenfelter, O. (1978). Estimating the effects of training programs on earnings. Review of Economics and Statistics 60: 47-57.

Ashenfelter, O. (1978). Union relative wage effects: new evidence and a survey of their implications on wage Inflation. New York, St. Martin's Press.

Bacon, N., Storey, J. (1993). Individualization of the employment relationship and the implications for trade unions. Employee Relations. Bradford 15(1): 5.

Barth, E., Raaum, O., Naylor, R. (January 1998). Union wage effects: does membership matter? The University of Warwick: 1-23.

Belman, D., Voos, Paula B (July 2004). Changes in union wage effects by industry: a fresh look at the evidence. Industrial Relations 43(3): 491-519.

Belman, D., Voos, Paula B (1993). Wages effects of increased union coverage: methodological considerations and new evidence. Industrial and Labor Relations Review 46(2): 368-380.

Belman, D., Heywood, J.S., Lund J. (July 1997). Public sector earnings and the extent of unionization. Industrial and Labor Relations Review 50(4): 610-628

Bender, K. A. (1998). The central government - private sector wage differential. Journal of Economic Surveys 12(2): 177-220.

Blanchflower, B., Bryson, A. (2002). Changes over time in union relative wage effects in Great Britain and the United States.

Blanchflower, D., Bryson, A. (2004). The union wage premium in the US and the UK. Centre for Economic Performance, LSE dp0612.

Blanchflower, D. G. (1997). Changes over time in union relative wage effects in Great Britain and the United States. In: Centre for Economic Performance \& Institute of Economics / Centre for Economic Performance \& Institute of Economics.

Blanchflower, D. G. (March 1991). Fear, unemployment and pay flexibility. Economic Journal: 483-496. 
Blanchflower, D. G., Freeman, R.B. (1992). Going different ways: unionism in the US and other OECD countries. Industrial Relations (Winter): 56-79.

Blanchflower, D. G. (1996). The role and influence of trade unions in the OECD. Centre for Economic Performance Discussion Paper No. 0310.

Blanchflower, D. G. (1984). Union relative wage effects: a cross-section analysis using establishment data. British Journal of Industrial Relations 22: 311-332.

Blanchflower, D. G., Oswald, A. J. (1994). The wage curve. Cambridge, Mass., MIT Press.

Blanchflower, D. G., Bryson, A (September 2003). What effect do unions have on wages now and would "What do unions do?' be surprised? NBER Working Paper Series Working Paper 9973.

Booth, A. (1995). The economics of the trade union. Cambridge, England, Cambridge University Press.

Booth, A. L., Bryan, M. L. ( April 2004). The Union membership wage premium puzzle: Is there a free-rider problem? Industrial and Labor Relations Review 57(3): 402-421

Boston, J., Martin, J., Pallot, J., Walsh, P. (1996). Public management: the New Zealand model. Auckland, Oxford University Press.

Bratsberg, B., Ragan, J. F. (October 2002). Changes in the union wage premium by industry. Industrial and Labor Relations Review 56(1): 65-83.

Brown, W., Deakin, S., Nash, D., Oxenbridge, S. (2000). The employment contract: from collective procedures to individual rights, ESRC Centre for Business Research.

Brown, W., Marginson, P., Welsh, J. (September 2001). The management of pay as the influence of collective bargaining diminishes, ESRC Centre for Business Research, University of Cambridge: 1-48.

Card, D. (1991). The effect of unions on distribution of wages: re-distribution or relabelling? Princetion University Department of Economics Working Papers (Working paper No. 287).

Card, D. (1996). The Effect of unions on the structure of wages: longitudinal analysis. Econometrica 64(July): 957-979.

Card, D. (2001). The effect of unions on wage inequality in the U.S. labor market. Industrial and Labor Relations Review 54(2): 296-315.

Card, D. (April 1998). Falling union membership and rising wage inequality: what's the connection? National Bureau of Economic Research: 1-41. 
Card, D., Lemieux, T, Riddell, W.C. (January 2003). Unionization and wage inequality: a comparative study of the U.S., the U.K., and Canada, National Bureau of Economic Research: 1-50.

Cardoso, A. R., Portugal, P. (2004). Bargained wages, wage drift and the design of the wage-setting system, CEPR.

Chaykowski, R. P., Slotsve, G.A. (1999). Unions, inequality, and the distribution of income in Canada: evidence from the 1994 survey of labour and income dynamics. Workplace Gazette 2(4): 85-99.

Choudhury;S. (1993). Reassessing the male-female wage differential: a fixed effects approach._Southern Economic Journal 60.

Christie, V. (1992). Union wage effects and the probability of union membership. Economic Record 68(200): 43-56.

Churchman, P. (2001). The Employment Relations Act: twelve months on. Law Conference.

Colbjǿrnsen, T., Kalleberg, A. (1988). Spillover, standardization and stratification: earnings determination in the United States and Norway. European Sociological Review 4: 20-31.

Commission, S. S. (June 2005). Human Resource Capability Survey of Public Service Departments as at 30 June 2005. Retrieved January 19, 2006, from http://www.ssc.govt.nz/hrc-survey-2005.

Crawford, A., Harbridge, R., Walsh, P. (1995). Privacy in the workplace: the effects of the Privacy Act 1993 on employment practices in New Zealand 1/95.

Curme, M. A., Macpherson, D. (1991). Union wage differentials and the effects of industry and local union density evidence from the 1980s. Journal of Labor Research 12(4): 419-427.

Dannin, E. J. (1997). Working free: the origins and impact of New Zealand's Employment Contracts Act. Auckland, Auckland University Press.

DiNardo, J., Hallock, K, F., Pischke, J. (May 2000). Unions and the labor market for managers, Institute for the Study of Labor: 1-50.

Disney, R., Gosling, A. (1998). Does it pay to work in the public sector? Fiscal Studies 19(4).

Fang, T., Verma, Anil (Winter 2002). Union wage premium. Perspectives (75-001XPE): 17-23.

Farber, H. S. (March 2003). Nonunion wage rates and the threat of unionization, Princeton University: 1-31. 
Farber, H. S. (2005). Union membership in the United States: the divergence between the public and private sectors Working paper \#503, Princeton University, Industrial relations section.

Flanders, A. D. (1970). Management and unions: the theory and reform of industrial relations. London, Faber.

Fogel, W., Lewin, D. (1974). Wage determination in the public sector. Industrial and Labor Relations Review 27(3 (Apr., 1974)): 410-431

Foster, A., C. (Spring 2000). Union-nonunion wage differences, 1997. Compensation and Working Conditions. B. o. L. Statistics.

Foster, B., McAndrew, I. (2003). Growth and innovation through good faith collective bargaining: an introduction. New Zealand Journal of Industrial Relations_28(2).

Foulkes, F. K. (1980). Personnel policies in large nonunion companies. Englewood Cliffs, N.J., Prentice-Hall.

Freeman, R. (July 1981 ). The Effects of unionism on fringe benefits Industrial and Labor Relations Review 34(4): 489-509.

Freeman, R., Medoff, J. L. (November 1981). The impact of the percentage organized on union and nonunion wages. The Review of Economics and Statistics 63(4): 561-572.

Freeman, R. B. (1980). Unionism and the dispersion of wages. Industrial \& Labor Relations Review 34(1): 3-23.

Freeman, R. B. (1982). Union wage practices and wage dispersion within establishments. Industrial \& Labor Relations Review 36(1): 3-21.

Freeman, R. B., Medoff, James L. (1984). What do unions do? New York, Basic Books.

Gregg, L. H. (1990). Union/nonunion wage gaps in public sector. Journal of Labour Economics 8(1): 260-328.

Gunderson, M. (1978). The influence of the status and sex composition of occupations on the male-female earnings gap. Industrial and Labor Relations Review 31(2 (Jan., 1978)): 217-226

Gunderson, M., Hyatt, D., Riddell, C. (February 2000). Pay differences between the government and private sectors: Labour Force Survey and Census Estimates, Canadian Policy Research Networks: 1-63.

Gunderson, M. ( May1979). Earnings differentials between the public and private sectors.The Canadian Journal of Economics / Revue canadienne_d'Economique 12(2): $228-242$ 
Gyourko, J., Tracy, J. (April 1988). An analysis of public and private sector wages allowing for endogenous choices of both government and union status. Journal of Labor Economics 6(2): 229-253.

Hansen, F. (1998). Union membership and the union wage differential. Compensation and Benefits Review 30(3): 16-21.

Harbridge, R., Honeybone, A. (1996). External legitimacy of unions: trends in New Zealand. Journal of Labour Research 17: 425-444.

Hildreth, A. K. G. (2000). Union Wage Differentials for covered members and nonmembers in Great Britain. Journal of Labour Research.

Hirsch, B. T., Neufeld, J (Winter 1987). Nominal and real union wage differentials and the effects of industry and SMSA density. The Journal of Human Resources 22(1): 138-148.

Hirsch, B. T., Schumacher, E.J. (Summer 2001). Private sector union density and the wage premium: past, present and future. Journal of Labor Research 22(3): 487518 .

Hirsch, B. T. (Spring 2004 ). Reconsidering union wage effects: surveying new evidence on an old topic. Journal of Labour Research 25(2): 233.

Hirsch, B. T., Macpherson, D. (2001). Union membership and earnings data book. Compilation for the Current Population Survey.

Hirsch, B. T., Schumacher, Edward J. (Winter 1998). Unions, wages, and skills. Journal of Human Resources 33(1): 201-219.

Jarrell, S. B., Stanley, T. D. (October 1990). A meta-analysis of the union-nonunion wage gap. Industrial and Labour Relations Review 44: 54-67.

Johnson, G. E., Youmans, Kenwood C. (1971). Union relative wage effects by age and education. Industrial and Labour Relations Review 24(2): 171-179.

Johnson, G. E., and Youmans, K. C. (1971). Union relative wage effects by age and education Industrial and Labour Relations Review 24(2 (Jan., 1971)): 171-179.

Kahn, L. M. (1978). The effects of unions on the earnings of nonunion workers. Industrial and Labor Relations Review 31(2 Jan., 1978)): 205-216

Kalleberg, A., Colbjǿrnsen, T. (1989). Unions and the structure of earnings inequality: explaining cross-national patterns of labour market segmentation. Working paper 23/89, Bergen:Norwegian Research Centre in Organization and Management.

Kelsey, J. (1997-1998). Employment and union issues in New Zealand - 12 years on symposium on New Zealand's Employment Contracts Act 1991 California Western International Law Journal 28: 253-274. 
Kornfeld, R. (October 1993). The effects of union membership on wages and employee benefits: The case of Australia. Industrial \& Labor Relations Review 47(1): 114128.

Lanot, G., Walker, I. (1998). The union/non-union wage differential: An application of semi-parametric methods. Journal of Econometrics, Elsevier 84(2): 327-349.

Layard, R., Nickell, S.J. (1985). The causes of British unemployment..National Institute Economic review 111: 62-85.

Lazear, E. P. (1983). A competitive theory of monopoly unionism. American Economic Review.

Le Grand, C. (1989). Interna arbetsmarknader, ekomomisk segmentering och social skikining, Stockholm: Institutet för social forskning.

Lemieux, T. (April 1998). Estimating the effects of unions on wage inequality in a panel data model with comparative advantage and nonrandom selection. Journal of Labor Economics 16(2): 261-291.

Lewis, G. (1986). The management of srategic change. Parkville, Victoria, Graduate School of Management, University of Melbourne.

Lewis, H. C. (1963). Unionism and relative wages in the United States. Chicago: University of Chicago Press.

Linneman, P. D., Wachter, M. L., Carter, W. H. (October 1990). "Evaluating the evidence on union employment and wages." Industrial and Labor Relations Review 44: 34-53.

Logan, J. (2006). The union avoidance industry in the United States. British Journal of Industrial Relations 44(4): 651-675.

Lonti, M. a. (2003). Identify and explore the impact of current pay fixing and bargaining structures and relevant pay systems in the Public Service on the gender pay gap.

Main, B. (1996). The union relative wage gap. Oxford, Oxford University Press.

Mastekaasa, A. (1993). Union-non-union wage differentials: individual level and organiztional level effects. European Sociological Review 9(2): 109-124.

Mellow, W. (February 1981). Unionism and wages: a longitudinal analysis.Review of Economics and Statistics 63(1): 43-52.

Metcalf, D., Hansen, K., Charlwood, A. (April 2001). Unions and the sword of justice: unions and pay systems, pay inequality and low pay. National Institute Economic Review 176: 61-75. 
Metcalf, D., Hansen, K., Charlwood, A., (2001 ). Unions and the sword of justice: unions and pay systems, pay inequality, pay discrimination and low pay. National Institute Economic Review 176(1): 61-75.

Miller, P. W., Mulvey, Charles (October 1994). Does compulsory arbitration neutralize union power? Industrial Relations 33(4): 492-504.

Miller, P. W., Mulvey, Charles, Neo, L.M. (1999). Union wage effects and the extent of the organisation. Australian Journal of Labour Economics 3: 65-92.

Miller, P. W., Mulvey, Charles (June 1996). "Unions, firm size, and wages. The Economic Record 72(217): 138-153.

Mishel, L., Walters, Matthew (August 2003). How unions help all workers. Economic Policy Institute Briefing Paper \#143.

Moll, P. (1993). Black South African unions: relative wage effects in international perspective. Industrial and Labor Relations Review 46(2): 245-262.

Moore, W. J., Raisian, John (1987). Union-Nonunion Wage Differentials in the Public Administration, Educational, and Private Sectors: 1970-1983. Review of Economics and Statistics 69(4): 608-616.

Moore, W. J., Raisian, J. (March 1991). Government wage differentials revisited. Journal of Labor Research 12(1): 13-33.

Mueller, R. E. (July 2000). Public and private sector wage differentials in Canada revisited. Industrial Relations 39(3).

Mulvey, C. (1986). Wage levels: do unions make a difference? wage fixation in Australia. J. Niland. Sydney, Allen and Unwin, Sydney.

Neumann, G., Pedersen, P. J., Westergard-Neilsen N. (1991). Long-run international trends in aggregate unionization. European Journal of Political Economy 7: 24974.

Neumark, D., Wachter, M. L. (October 1995). Union effects on nonunion wages: evidence from panel data on industries and cities. Industrial and Labor Relations Review 49(1): 20-38.

Norman, R. (2001). Letting and making managers manage the effect of control systems on management action in New Zealand's central government. International Public Management Journal 4: 65-89.

Park, Y. (1991). Union/non-union wage differentials in the Korean manufacturing sector. International Economic Journal 5(4): 79-91.

Peetz, D. (September 2001). Individual contracts, collective bargaining, wages and power. Australian National University, Centre for Economic Policy Research. 
Peetz, D., Preston, A. (2008). Wages under AWAs and collective agreements. workers, corporations, and community: facing choices for a sustainable future. 22nd AIRAANZ Conference. 6-8 February 2008 St Kilda, Melbourne, Australia. 2(Non-refereed papers and abstracts): $306-315$.

Pencavel, J. (1972). Wages, specific training, and labor turnover in US manufacturing industries. International Economic Review.

Podgursky, M. (1986). Unions, establishment size, and intra-industry threat effects. Industrial and labour Relations Review 39: 277-84.

Powell, R. L. (1989). The state of unions in Africa: "CHIPPING" AWAY AT THE UNION "BLOCK." J. Marshall L. Rev. 23(707).

Prescott, D., Wandschneider, B. (1999). Public/private sector wage differentials in Canada - evidence from the 1991 and 1982 surveys of consumer finance. Applied Economics 31:723-731.

Robinson, C., Tomes, N. (1984). Union wage differentials in the public and private sectors: a simultaneous equation specification. Journal of Labor Economics 2:106127.

Robinson, C. (1989). The joint determination of union status and union wage effects: some tests of alternative models. Journal of Political Economy 97(3): 639-667.

Robinson, C. (1995). Union incidence in the public and private sectors. Canadian Journal of Economics 28(4b): 1056-1076.

Rosen, S. (1969). Trade union power, threat effects and the extent of organization. Review of Economic Studies 36: 185-196.

Schick, A. (February 1998). Why most developing countries should not try New Zealand reforms. The World Bank Research Observer 13(1): 123-131.

Schmidt, C. (1995). Relative wage effects of German unions, mimeo, Selapo, University of Munich.

Schmidt, C., Zimmermann, K. F. (1995). Work characteristics, firm size and wages. Review of Economics and Statistics 73(4): 705-710.

Schumacher, E. J. (January 1999). What explains wage differences between union members and covered nonmembers? Southern Economic Journal 65: 493-512.

Schwenk, A. E. (September 1996). Trends in the differences between union and nonunion workers in pay using the Employment Cost Index. Compensation and Working Conditions 1: 27-33.

Shah, A. (1984). Job attributes and the size of the union/non-union wage differential. Economica 51: 437-446. 
Simpson, W. (1985). "The impact of unions on the structure of Canadian wages: an empirical analysis with micro data." Canadian Journal of Economics 18: 164-181.

Smith, S. P. (October 1977). Pay differentails between federal government and private sector workers: reply. Industrial and Labor Relations Review 31(1): 82-87.

Stewart, M. B. (1983). Relative earnings and individual union membership in the United Kingdom. Economica 50(198): 111-125.

Stewart, M. B. (May 1995). Union wage differentials in an era of declining unionization. Oxford Bulletin of Economics and Statistics 57(2): 143-166.

Stewart, M. B. (1987). Collective bargaining arrangements, closed shops and relative pay. Economic Journal 97: 140-156.

Stewart, M. B. (1991). Union wage differentials in the face of changes in the economic and legal environment. Economica 58: 155-172.

Tabachnick, B. G., Fidell, L. S. (2001). Using multivariate statistics (4th edn). New York: HarperCollins.

Turnbull, P. (Summer 2003). What do unions do now? Journal of Labor Research 24(3): 491-527.

Waddoups, C. J. (October 2005). Trade union decline and union wage effects in Australia." Industrial Relations 44(4): 607-624.

Wagner, J. (1991). "Gewerkschaftsmitgliedschaft and arbeitseinkommen in der Bundesrepublik" Deutschland. Ifo-Studen: 109-40.

Walsh, P., Harbridge, Raymond, Crawford, A., (2001). Public sector industrial relations in New Zealand. strategic choices in reforming public service employment: an international handbook. C. Dell'Aringa, Rocca, Giuseppe Della, Keller, Berndt. New York, Palgrave: 185-215.

Walsh, P. (1991b). The dilemmas of governance: state-building and industrial relations in the public sector.

Walsh, P., Bryson, J, Lonti, Z (2002). "Jack be nimble, Jill be quick': HR capability and organizational agility in the New Zealand public and private sectors." Asia Pacific Journal of Human Resources 40(2): 177-192.

Wooden, M. (March 2001b). Union wage effects in the presence of enterprise bargaining. The Economic Record 77(236): 1-18.

Zigray, T. (2005). look in the mirror. PTI Power Source Newsletter. Available http://www.tbglabour.com/news.aspx?newsID=78. 


\section{APPENDICES}

\section{Appendix One: Table One - Variable Definitions}

\begin{tabular}{|c|c|}
\hline Gender & Female or male (3 employees refused - were not included) \\
\hline & 1 if employee is male; 0 if otherwise \\
\hline Ethnicity & Classification is based on level 3 and 4 of NZSCE produced by Statistics New Zealand \\
\hline & $\begin{array}{l}\text { New Zealand European (Pakeha) }=1 \text { if employee is New Zealand } \\
\text { European; } 0 \text { if otherwise }\end{array}$ \\
\hline & Maori $=1$ if employee is Maori; 0 if otherwise \\
\hline & Asian $=1$ if employee is Asian; 0 if otherwise \\
\hline & Non-NZ European $=1$ if employee is non-NZ European; 0 if otherwise \\
\hline & Pacific Islander $=1$ if employee is Pacific Islander; 0 if otherwise \\
\hline & $\begin{array}{l}\text { Other Ethnic Groups }=1 \text { if employee is Other Ethnic Groups; } 0 \text { if } \\
\text { otherwise }\end{array}$ \\
\hline & Unknown $=1$ if employee is unknown; 0 if otherwise \\
\hline & $\begin{array}{l}\text { Note: "New Zealander" is not regarded as an ethnicity and is coded to } \\
\text { "unknown" }\end{array}$ \\
\hline $\begin{array}{l}\text { Two Digit } \\
\text { NZSCO }\end{array}$ & \\
\hline & $\begin{array}{l}11 \text { (Legislative and Admin })=1 \text { if employee is legislative or admin; } 0 \text { if } \\
\text { otherwise }\end{array}$ \\
\hline & $\begin{array}{l}12 \text { (Corporate Manager) }=1 \text { if employee is corporate manager; } 0 \text { if } \\
\text { otherwise }\end{array}$ \\
\hline & $\begin{array}{l}21 \text { (Physical, Mathematical and Engineering Science Profession) }=1 \text { if } \\
\text { employee is physical, mathematical and engineering science profession; } \\
0 \text { if otherwise }\end{array}$ \\
\hline & $\begin{array}{l}22 \text { (Live Science and Health Professions) }=1 \text { if employee is live science } \\
\text { and health profession; } 0 \text { if otherwise }\end{array}$ \\
\hline & $\begin{array}{l}23 \text { (Teaching Profession })=1 \text { if employee is teaching profession; } 0 \text { if } \\
\text { otherwise }\end{array}$ \\
\hline & $24($ Other Profession $)=1$ if employee is other profession; 0 if otherwise \\
\hline & $\begin{array}{l}3 \text { (Associate Profession) }=1 \text { if employee is associate profession; } 0 \text { if } \\
\text { otherwise }\end{array}$ \\
\hline & $4($ Clerk $)=1$ if employee is clerk; 0 if otherwise \\
\hline & $\begin{array}{l}5 \text { (Labourers and Trade Workers) }=1 \text { if employee is labourer and trade } \\
\text { workers; } 0 \text { if otherwise }\end{array}$ \\
\hline & $6($ Unknown $)=1$ if employee is unknown; 0 if otherwise \\
\hline $\begin{array}{l}\text { Contract } \\
\text { Term }\end{array}$ & Fixed (temporary) or open term (permanent) \\
\hline & \begin{tabular}{|l|l|} 
& 1 if employee is permanent; 0 if otherwise \\
\end{tabular} \\
\hline Tenure & Length of service (years) in the same organization \\
\hline & Less than 1 year $=1$ if employee is less than 1 year; 0 if otherwise \\
\hline & 1 year $=1$ if employee is 1 year; 0 if otherwise \\
\hline & 2 years $=1$ if employee is 2 years; 0 if otherwise \\
\hline
\end{tabular}




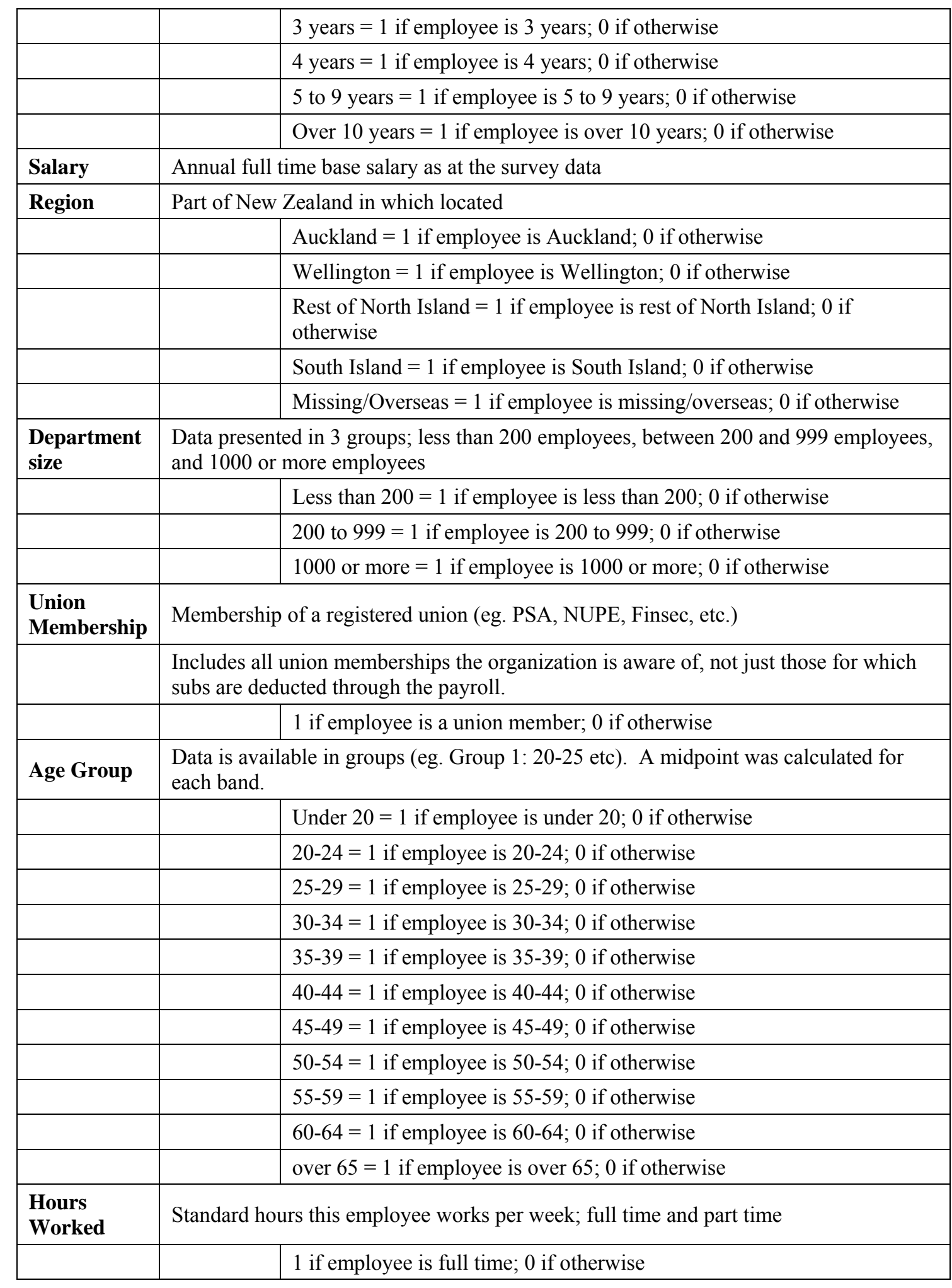




\section{Appendix Two: Table One - Numbers of Observations}

\begin{tabular}{|c|c|c|c|}
\hline & $\begin{array}{c}\text { All } \\
\mathrm{N} \text { and (\%) }\end{array}$ & $\begin{array}{l}\text { Collective } \\
\mathrm{N} \text { and (\%) }\end{array}$ & $\begin{array}{l}\text { Individual } \\
\mathrm{N} \text { and (\%) }\end{array}$ \\
\hline All employees & 40,290 & $21,878(54.3)$ & $18,412(45.7)$ \\
\hline Gender: & 40,287 (99.9) & $21,878(54.3)$ & $18,409(45.7)$ \\
\hline Women & $23,833(59.2)$ & $13,107(55)$ & $10,726(45)$ \\
\hline Men & 16,454 & $8,771(53)$ & $7,683(47)$ \\
\hline Open -term & $36,611(90.8)$ & $21,280(58.1)$ & $15,331(41.9)$ \\
\hline Fixed- term & 3,679 & $598(16.3)$ & $3,081(83.7)$ \\
\hline Union member & 23,281 & $19,127(82.2)$ & $4,154(17.8)$ \\
\hline PSA & $17,664(75.9)$ & $1,948(84.6)$ & $2,716(15.4)$ \\
\hline Full-time & $36,699(91.1)$ & $20,069(54.7)$ & $16,630(45.3)$ \\
\hline Part-time & 3,591 & $1,809(50.4)$ & $1782(49.6)$ \\
\hline Employer size (ees): & 40,290 & $21,878(54.3)$ & $18,412(45.7)$ \\
\hline$>200$ & $974(2.4)$ & $150(15.4)$ & 824 (84.6) \\
\hline 200-999 & $5,136(12.7)$ & $2,148(41.8)$ & $2,988(58.2)$ \\
\hline $1000+$ & $34,180(84.9)$ & $19,580(56.5)$ & $14,600(43.5)$ \\
\hline $\begin{array}{l}\text { Occupational } \\
\text { category: }\end{array}$ & 40,290 & $21,878(54.3)$ & $18,412(45.7)$ \\
\hline Legislative and admin & $75(0.2)$ & $26(34.7)$ & $49(65.3)$ \\
\hline Corporate manager & $3,895(9.7)$ & $763(19.6)$ & $3,132(80.4)$ \\
\hline $\begin{array}{l}\text { Physical, } \\
\text { Mathematical \& } \\
\text { Engineering Science } \\
\text { Professionals }\end{array}$ & $1,057(2.6)$ & $371(35.1)$ & $686(64.9)$ \\
\hline $\begin{array}{l}\text { Life Science \& Health } \\
\text { Professionals }\end{array}$ & $1,008(2.5)$ & $636(63.1)$ & $372(36.9)$ \\
\hline $\begin{array}{l}\text { Teaching } \\
\text { Professionals }\end{array}$ & $2,083(5.2)$ & $1,009(48.4)$ & $1,074(51.6)$ \\
\hline Other Professionals & 7,631 (18.9) & $2,960(38.8)$ & $4,671(61.2)$ \\
\hline $\begin{array}{l}\text { Associate } \\
\text { Professionals }\end{array}$ & $13,960(36.6)$ & $9,206(65.9)$ & $4,754(34.1)$ \\
\hline Clerks & $7,047(17.5)$ & $4,497(63.8)$ & $2,550(36.2)$ \\
\hline $\begin{array}{l}\text { Labourers and Trade } \\
\text { Workers }\end{array}$ & $3,078(7.6)$ & $2,272(73.8)$ & $806(26.2)$ \\
\hline Response Unknown & $456(1.1)$ & $138(30.3)$ & $318(69.7)$ \\
\hline Age: & $39,511(98.1)$ & $21,655(54.8)$ & $17,856(43.2)$ \\
\hline$>20$ & $310(0.8)$ & $134(43.2)$ & $176(56.8)$ \\
\hline $20-24$ & $2,265(5.7)$ & $1,089(48.1)$ & $1,176(51.9)$ \\
\hline $25-29$ & $4,069(10.3)$ & $1,927(47.4)$ & $2,142(52.6)$ \\
\hline
\end{tabular}




\begin{tabular}{|c|c|c|c|}
\hline $30-34$ & $4932(12.5)$ & $2,433(49.3)$ & $2,499(50.7)$ \\
\hline $35-39$ & $5519 \quad(14)$ & $2,897(52.5)$ & $2,622(47.5)$ \\
\hline $40-44$ & 6,194 (15.7) & $3,443(55.6)$ & $2,751(44.4)$ \\
\hline $45-49$ & $5,702(14.4)$ & $3,281(58.0)$ & $2,421(42.0)$ \\
\hline $50-54$ & $4,645(11.8)$ & $2,774(59.7)$ & $1,871(40.3)$ \\
\hline $55-59$ & $3,554(9)$ & $2,183(61.4)$ & $1,371(38.6)$ \\
\hline $60-64$ & $1,823 \quad(4.6)$ & $1,171(64.2)$ & $652(35.8)$ \\
\hline $65+$ & $498 \quad(1.3)$ & $323(64.9)$ & $175(35.1)$ \\
\hline Tenure (years): & $40,289(99.9)$ & $21,878(54.3)$ & $18,411(45.7)$ \\
\hline$>1$ & $8,347(20.7)$ & $2,736(32.8)$ & $5,611(67.2)$ \\
\hline 1 & $5,239(13)$ & $2,374(45.3)$ & $2,865(54.7)$ \\
\hline 2 & $3,491(8.7)$ & $1,734(49.7)$ & $1,757(50.3)$ \\
\hline 3 & $2,699(6.7)$ & $1,421(52.6)$ & $1,278(47.4)$ \\
\hline 4 & $2,752(6.8)$ & $1,618(58.8)$ & $1,134(41.2)$ \\
\hline $5-9$ & $6,682(16.6)$ & $3,965(59.3)$ & $2,717(40.7)$ \\
\hline $10+$ & $11,079(27.5)$ & $8,030(72.5)$ & $3,049(27.5)$ \\
\hline Ethnicity: & 40,290 & $21,655(55.7)$ & $17,856(44.3)$ \\
\hline Pacific Islanders & $2,183(5.4)$ & $1,391(64.7)$ & $792(36.3)$ \\
\hline Asians & $1,803(4.5)$ & $985(54.6)$ & $818(45.4)$ \\
\hline NZ European & $21,971(54.5)$ & $11,698(53.2)$ & $10,273(46.8)$ \\
\hline Maori & $5,914(15.7)$ & $3,626(61.3)$ & $2,288(38.7)$ \\
\hline Non-NZ Europeans & $3,433(8.5)$ & $1,617(47.1)$ & $1,816(52.9)$ \\
\hline Other Ethnic Group & $438(1.1)$ & $225(51.4)$ & $213(48.6)$ \\
\hline Unknown & $4,548(11.3)$ & $2,336(51.4)$ & $2,212(48.6)$ \\
\hline Region: & 40,290 & $21,878(54.3)$ & $18,412(45.7)$ \\
\hline Auckland & $8,176(20.3)$ & $5,344(65.4)$ & $2,832(34.6)$ \\
\hline Wellington & $16,159(40.1)$ & $6,074(37.6)$ & $10,085(62.4)$ \\
\hline Rest of North Island & $9,060(22.5)$ & $5,970(65.9)$ & $3,090(34.1)$ \\
\hline South Island & $6,639(16.5)$ & $4,331(65.2)$ & $2,308(34.8)$ \\
\hline Missing/Overseas & $256(0.6)$ & $159(62.1)$ & $97(37.9)$ \\
\hline
\end{tabular}




\section{Appendix Two: Table Two - Mean values of variables and pay differentials}

\begin{tabular}{|c|c|c|c|c|c|c|c|c|}
\hline & \multirow[t]{2}{*}{ All (\$) } & \multicolumn{3}{|c|}{ Collecolllctive } & \multicolumn{3}{|c|}{ Individual } & \multirow{2}{*}{$\begin{array}{c}\text { Pay } \\
\text { Differential } \\
(\%)\end{array}$} \\
\hline & & $\$$ & $\mathbf{N}$ & $\begin{array}{l}\text { Std. } \\
\text { Error }\end{array}$ & $\$$ & $\mathbf{N}$ & $\begin{array}{l}\text { Std. } \\
\text { Error }\end{array}$ & \\
\hline All employees & $\$ 50,689$ & $\$ 44,561$ & 21878 & $\$ 85.37$ & $\$ 57,970$ & 18412 & $\$ 223.95$ & -23.1 \\
\hline Women & $\$ 47,035$ & $\$ 43,163$ & 10726 & $\$ 102$ & $\$ 51,720$ & 10726 & $\$ 252$ & -16.5 \\
\hline Men & $\$ 55,982$ & $\$ 46,605$ & 7683 & $\$ 145$ & $\$ 66,687$ & 7683 & $\$ 384$ & -30.1 \\
\hline Open -term & $\$ 51,426$ & $\$ 44,741$ & 21280 & $\$ 86$ & $\$ 60,705$ & 15331 & $\$ 245$ & -26.3 \\
\hline Fixed- term & $\$ 43,354$ & $\$ 38,154$ & 598 & $\$ 587$ & $\$ 44,363$ & 3081 & $\$ 487$ & -14.0 \\
\hline Full-time & $\$ 51,156$ & $\$ 44,573$ & 20069 & $\$ 89$ & $\$ 59,100$ & 16630 & $\$ 238$ & -24.6 \\
\hline Part-time & $\$ 45,913$ & $\$ 44,424$ & 1809 & $\$ 287$ & $\$ 47,424$ & 1782 & $\$ 606$ & -6.3 \\
\hline \multicolumn{9}{|l|}{ Age: } \\
\hline$>20$ & $\$ 28,747$ & $\$ 30,008$ & 134 & $\$ 253$ & $\$ 27,787$ & 176 & $\$ 303$ & 8.0 \\
\hline $20-24$ & $\$ 35,208$ & $\$ 34,836$ & 1089 & $\$ 156$ & $\$ 35,552$ & 1176 & $\$ 198$ & -2.0 \\
\hline $25-29$ & $\$ 41,743$ & $\$ 38,941$ & 1927 & $\$ 179$ & $\$ 44,264$ & 2142 & $\$ 279$ & -12.0 \\
\hline $30-34$ & $\$ 47,706$ & $\$ 43,062$ & 2433 & $\$ 232$ & $\$ 52,228$ & 2499 & $\$ 396$ & -17.5 \\
\hline $35-39$ & $\$ 51,392$ & $\$ 44,536$ & 2897 & $\$ 226$ & $\$ 58,968$ & 2622 & $\$ 554$ & -24.5 \\
\hline $40-44$ & $\$ 53,505$ & $\$ 45,439$ & 3443 & $\$ 216$ & $\$ 63,600$ & 2751 & $\$ 610$ & -28.6 \\
\hline $45-49$ & $\$ 55,141$ & $\$ 46,893$ & 3281 & $\$ 231$ & $\$ 66,319$ & 2421 & $\$ 728$ & -29.3 \\
\hline $50-54$ & $\$ 56,424$ & $\$ 47,468$ & 2774 & $\$ 245$ & $\$ 69,702$ & 1871 & $\$ 833$ & -31.9 \\
\hline $55-59$ & $\$ 56,638$ & $\$ 47,851$ & 2183 & $\$ 290$ & $\$ 70,628$ & 1371 & $\$ 1,016$ & -32.2 \\
\hline $60-64$ & $\$ 52,519$ & $\$ 46,385$ & 1171 & $\$ 424$ & $\$ 63,537$ & 652 & $\$ 1,263$ & -27.0 \\
\hline $65+$ & $\$ 47,751$ & $\$ 44,256$ & 323 & $\$ 685$ & $\$ 54,201$ & 175 & $\$ 1,678$ & -18.3 \\
\hline \multicolumn{9}{|l|}{ Tenure (years): } \\
\hline$>1$ & $\$ 44,662$ & $\$ 37,305$ & 2736 & $\$ 207$ & $\$ 48,250$ & 5611 & $\$ 356$ & -22.7 \\
\hline 1 & $\$ 46,065$ & $\$ 39,847$ & 2374 & $\$ 229$ & $\$ 51,217$ & 2865 & $\$ 484$ & -22.2 \\
\hline 2 & $\$ 48,463$ & $\$ 41,392$ & 1734 & $\$ 264$ & $\$ 55,441$ & 1757 & $\$ 630$ & -25.3 \\
\hline 3 & $\$ 51,507$ & $\$ 43,436$ & 1421 & $\$ 298$ & $\$ 60,481$ & 1278 & $\$ 819$ & -28.2 \\
\hline 4 & $\$ 51,083$ & $\$ 43,630$ & 1618 & $\$ 272$ & $\$ 61,715$ & 1134 & $\$ 836$ & -29.3 \\
\hline 5 to 9 & $\$ 53,501$ & $\$ 45,336$ & 3965 & $\$ 177$ & $\$ 65,418$ & 2717 & $\$ 606$ & -30.7 \\
\hline $10+$ & $\$ 56,124$ & $\$ 49,115$ & 8030 & $\$ 148$ & $\$ 74,582$ & 3049 & $\$ 611$ & -34.1 \\
\hline \multicolumn{9}{|l|}{ Ethnicity: } \\
\hline Pacific Islanders & $\$ 40,833$ & $\$ 39,400$ & 1391 & $\$ 209$ & $\$ 43,349$ & 792 & $\$ 611$ & -9.1 \\
\hline Asians & $\$ 46,379$ & $\$ 41,668$ & 985 & $\$ 378$ & $\$ 52,052$ & 818 & $\$ 874$ & -19.9 \\
\hline NZ European & $\$ 52,761$ & $\$ 45,723$ & 11698 & $\$ 120$ & $\$ 60,774$ & 10273 & $\$ 319$ & -24.8 \\
\hline Maori & $\$ 45,301$ & $\$ 41,805$ & 3626 & $\$ 165$ & $\$ 50,841$ & 2288 & $\$ 499$ & -17.8 \\
\hline Non-NZ Europeans & $\$ 54,735$ & $\$ 46,771$ & 1617 & $\$ 354$ & $\$ 61,827$ & 1816 & $\$ 713$ & -24.4 \\
\hline Other Ethnic Group & $\$ 50,959$ & $\$ 46,283$ & 225 & $\$ 1,105$ & $\$ 55,899$ & 213 & $\$ 1,766$ & -17.2 \\
\hline Unknown & $\$ 51,046$ & $\$ 45,615$ & 2336 & $\$ 288$ & $\$ 56,782$ & 2212 & $\$ 637$ & -19.7 \\
\hline
\end{tabular}




\begin{tabular}{|l|c|c|c|c|c|c|c|c|}
\hline Employer size (ees): & & & & & & & & \\
\hline \multicolumn{1}{|c|}{$>200$} & $\$ 70,271$ & $\$ 52,889$ & 150 & $\$ 1,849$ & $\$ 73,436$ & 824 & $\$ 1,310$ & -28.0 \\
\hline \multicolumn{1}{|c}{$1000+999$} & $\$ 62,807$ & $\$ 54,264$ & 2148 & $\$ 359$ & $\$ 68,748$ & 2988 & $\$ 650$ & -21.1 \\
\hline $\begin{array}{l}\text { Occupational } \\
\text { category: }\end{array}$ & $\$ 48,310$ & $\$ 43,433$ & 19580 & $\$ 82$ & $\$ 54,851$ & 14600 & $\$ 231$ & -20.8 \\
\hline Legislative and admin & $\$ 121,266$ & $\$ 91,271$ & 26 & $\$ 2,081$ & $\$ 137,182$ & 49 & $\$ 4,613$ & -33.5 \\
\hline Corporate manager & $\$ 84,676$ & $\$ 58,354$ & 763 & $\$ 593$ & $\$ 91,089$ & 3132 & $\$ 674$ & -35.9 \\
\hline $\begin{array}{l}\text { Physical, Mathematical } \\
\text { \& Engineering Science } \\
\text { Professionals }\end{array}$ & $\$ 63,231$ & $\$ 57,699$ & 371 & $\$ 687$ & $\$ 66,222$ & 686 & $\$ 789$ & -12.9 \\
\hline $\begin{array}{l}\text { Life Science \& Health } \\
\text { Professionals }\end{array}$ & $\$ 56,199$ & $\$ 51,531$ & 636 & $\$ 513$ & $\$ 64,181$ & 372 & $\$ 1,313$ & -19.7 \\
\hline Teaching Professionals & $\$ 41,343$ & $\$ 50,092$ & 1009 & $\$ 435$ & $\$ 33,123$ & 1074 & $\$ 471$ & 51.2 \\
\hline Other Professionals & $\$ 63,585$ & $\$ 57,343$ & 2960 & $\$ 290$ & $\$ 67,541$ & 4671 & $\$ 380$ & -15.1 \\
\hline $\begin{array}{l}\text { Associate } \\
\text { Professionals }\end{array}$ & $\$ 41,889$ & $\$ 41,333$ & 9206 & $\$ 93$ & $\$ 42,965$ & 4754 & $\$ 203$ & -3.8 \\
\hline Clerks & $\$ 38,744$ & $\$ 38,170$ & 4497 & $\$ 106$ & $\$ 39,756$ & 2550 & $\$ 223$ & -4.0 \\
\hline $\begin{array}{l}\text { Labourers and Trade } \\
\text { Workers }\end{array}$ & $\$ 41,599$ & $\$ 41,730$ & 2272 & $\$ 131$ & $\$ 41,232$ & 806 & $\$ 400$ & 1.2 \\
\hline Response Unknown & $\$ 49,754$ & $\$ 47,670$ & 138 & $\$ 131$ & $\$ 50,659$ & 318 & $\$ 1,252$ & -5.9 \\
\hline Region: & $\$ 43,752$ & $\$ 42,076$ & 5344 & $\$ 141$ & $\$ 46,913$ & 2832 & $\$ 373$ & -10.3 \\
\hline Auckland & $\$ 60,259$ & $\$ 49,245$ & 6074 & $\$ 205$ & $\$ 66,893$ & 10086 & $\$ 373$ & -26.4 \\
\hline Wellington & $\$ 43,303$ & $\$ 44,293$ & 5970 & $\$ 127$ & $\$ 45,256$ & 3090 & $\$ 345$ & -2.1 \\
\hline Rest of North Island & $\$ 44,753$ & $\$ 43,304$ & 4331 & $\$ 155$ & $\$ 47,472$ & 2308 & $\$ 417$ & -8.8 \\
\hline South Island & $\$ 68,535$ & 159 & $\$ 1,514$ & $\$ 107,942$ & 97 & $\$ 4,259$ & -36.5 \\
\hline Missing/Overseas & & & & & & & \\
\hline
\end{tabular}




\section{Appendix Two: Table Three - Pearson Correlations}

\begin{tabular}{|c|c|c|c|c|c|c|c|c|c|c|c|c|}
\hline & & Ethnicity & $\begin{array}{l}\text { 2-digit } \\
\text { NZSCO }\end{array}$ & $\begin{array}{l}\text { Contract } \\
\text { Term }\end{array}$ & Tenure & $\begin{array}{c}\text { FTE } \\
\text { Salary }\end{array}$ & $\begin{array}{c}5 \\
\text { Regions }\end{array}$ & $\begin{array}{l}\text { Organization } \\
\text { Size }\end{array}$ & Age & $\begin{array}{l}\text { Full time } \\
\text { or Part } \\
\text { time }\end{array}$ & $\begin{array}{l}\text { Contract } \\
\text { type }\end{array}$ & $\begin{array}{c}\text { Union } \\
\text { membership }\end{array}$ \\
\hline \multirow[t]{3}{*}{ FTE Salary } & $\begin{array}{l}\text { Correlation } \\
\text { coefficient }\end{array}$ & $-0.016^{* *}$ & $-.424^{* *}$ & $.099 * *$ & $.183 * *$ & 1 & $1.067 * *$ & $-.241 * *$ & $.217^{* *}$ & $-0.64 * *$ & $-.284 * *$ & $-.231 * *$ \\
\hline & $\begin{array}{l}\text { Sig. (2- } \\
\text { tailed) }\end{array}$ & 0.001 & 0.000 & 0.000 & 0.000 & & 0.000 & 0.000 & 0.000 & 0.000 & 0.000 & 0.000 \\
\hline & $\mathrm{N}$ & 40290 & 40290 & 40290 & 40289 & 40290 & 40290 & 40290 & 39511 & 40290 & 40290 & 37539 \\
\hline \multirow[t]{3}{*}{ Contract type } & $\begin{array}{l}\text { Correlation } \\
\text { coefficient }\end{array}$ & $-.024 * *$ & $.202 * *$ & $.242 * *$ & $.277 * *$ & $-.284 * *$ & $-082 * *$ & $.159 * *$ & $.104 * *$ & $-.025^{* *}$ & 1 & $.798 * *$ \\
\hline & $\begin{array}{l}\text { Sig. (2- } \\
\text { tailed) }\end{array}$ & 0.000 & 0.000 & 0.000 & 0.000 & 0.000 & 0.000 & 0.000 & 0.000 & 0.000 & & 0.000 \\
\hline & $\mathrm{N}$ & 40290 & 40290 & 40290 & 40289 & 40290 & 40290 & 40290 & 39511 & 40290 & 40290 & 37539 \\
\hline \multirow[t]{3}{*}{$\begin{array}{l}\text { Union } \\
\text { membership } \\
\text { status }\end{array}$} & $\begin{array}{l}\text { Correlation } \\
\text { coefficient }\end{array}$ & $-.032 * *$ & $.149 * *$ & $.192 * *$ & $.273 * *$ & $-.231 * *$ & $.086^{* *}$ & $.128 * *$ & $.126^{* *}$ & $-.049 * *$ & $.798 * *$ & 1 \\
\hline & $\begin{array}{l}\text { Sig. (2- } \\
\text { tailed) }\end{array}$ & 0.000 & 0.000 & 0.000 & 0.000 & 0.000 & 0.000 & 0.000 & 0.000 & 0.000 & 0.000 & \\
\hline & $\mathrm{N}$ & 37539 & 37539 & 37539 & 37538 & 37539 & 37539 & 37539 & 36841 & 37539 & 37539 & 37539 \\
\hline
\end{tabular}

$* *=$ Correlation is significant at the 0.01 level (2-tailed). 


\section{Appendix Three - Regression One:}

\begin{tabular}{|c|c|c|c|c|c|}
\hline \multicolumn{2}{|c|}{ Model Summary } & \multirow[b]{2}{*}{ Adjusted R Square } & \multirow[b]{2}{*}{ Std. Error of the Estimate } & & \\
\hline $\mathbf{R}$ & R Square & & & & \\
\hline 0.762 & 0.580 & 0.580 & 0.104 & & \\
\hline \multicolumn{6}{|l|}{ ANOVA } \\
\hline Model & Sum of Squares & df & Mean Square & $\mathbf{F}$ & Sig \\
\hline Regression & 602.792 & 42 & 14.352 & 1324.599 & 0.000 \\
\hline Residual & 436.081 & 40247 & 0.011 & & \\
\hline \multirow[t]{3}{*}{ Total } & 1038.873 & 40289 & & & \\
\hline & Unstandardized Coefficients & & & & \\
\hline & B & Std. Error & Sig. & & \\
\hline Intercept & 4.662 & 0.007 & 0.000 & & \\
\hline Gender & 0.027 & 0.001 & 0.000 & & \\
\hline Contract Term & 0.054 & 0.002 & 0.000 & & \\
\hline Hours Worked & 0.015 & 0.002 & 0.000 & & \\
\hline Contract Type & -0.028 & 0.001 & 0.000 & & \\
\hline $\begin{array}{l}\text { Union } \\
\text { membership }\end{array}$ & -0.016 & 0.001 & 0.000 & & \\
\hline \multicolumn{6}{|l|}{ Age: } \\
\hline$>20$ & -0.106 & 0.007 & 0.000 & & \\
\hline $20-24$ & -0.062 & 0.004 & 0.000 & & \\
\hline $25-29$ & -0.03 & 0.003 & 0.000 & & \\
\hline $30-34$ & 0.005 & 0.003 & 0.106 & & \\
\hline $35-39$ & 0.021 & 0.003 & 0.000 & & \\
\hline $40-44$ & 0.03 & 0.003 & 0.000 & & \\
\hline $45-49$ & 0.036 & 0.003 & 0.000 & & \\
\hline $50-54$ & 0.041 & 0.003 & 0.000 & & \\
\hline $55-59$ & 0.037 & 0.003 & 0.000 & & \\
\hline $60-64$ & 0.021 & 0.004 & 0.000 & & \\
\hline $65+$ & $*$ & $*$ & $*$ & & \\
\hline \multicolumn{6}{|l|}{ Tenure (years): } \\
\hline$>1$ & -0.063 & 0.002 & 0.000 & & \\
\hline 1 & -0.051 & 0.002 & 0.000 & & \\
\hline 2 & -0.041 & 0.002 & 0.000 & & \\
\hline 3 & -0.026 & 0.002 & 0.000 & & \\
\hline 4 & -0.024 & 0.002 & 0.000 & & \\
\hline 5 to 9 & -0.014 & 0.002 & 0.000 & & \\
\hline $10+$ & $*$ & $*$ & $*$ & & \\
\hline
\end{tabular}




\begin{tabular}{|c|c|c|c|}
\hline Ethnicity: & & & \\
\hline Pacific Islanders & $*$ & $*$ & $*$ \\
\hline Asians & 0.009 & 0.003 & 0.004 \\
\hline NZ European & 0.033 & 0.002 & 0.000 \\
\hline Maori & 0.02 & 0.003 & 0.000 \\
\hline $\begin{array}{l}\text { Non-NZ } \\
\text { Europeans }\end{array}$ & 0.042 & 0.003 & 0.000 \\
\hline Other Ethnic & 0.026 & 0.005 & 0.000 \\
\hline Unknown & 0.022 & 0.003 & 0.000 \\
\hline Employer size & & & \\
\hline$>200$ & 0.028 & 0.003 & 0.000 \\
\hline $200-999$ & 0.028 & 0.002 & 0.000 \\
\hline $1000+$ & $*$ & $*$ & $*$ \\
\hline $\begin{array}{l}\text { Occupational } \\
\text { category: }\end{array}$ & & & \\
\hline $\begin{array}{l}\text { Legislative and } \\
\text { admin }\end{array}$ & 0.264 & 0.015 & 0.000 \\
\hline $\begin{array}{l}\text { Corporate } \\
\text { manager }\end{array}$ & 0.149 & 0.005 & 0.000 \\
\hline $\begin{array}{l}\text { Physical, } \\
\text { Mathematical \& } \\
\text { Engineering } \\
\text { Science } \\
\text { Professionals } \\
\end{array}$ & 0.044 & 0.006 & 0.000 \\
\hline $\begin{array}{l}\text { Life Science \& } \\
\text { Health } \\
\text { Professionals }\end{array}$ & 0.031 & 0.006 & 0.000 \\
\hline $\begin{array}{l}\text { Teaching } \\
\text { Professionals }\end{array}$ & -0.071 & 0.005 & 0.000 \\
\hline $\begin{array}{l}\text { Other } \\
\text { Professionals }\end{array}$ & 0.054 & 0.005 & 0.000 \\
\hline $\begin{array}{l}\text { Associate } \\
\text { Professionals }\end{array}$ & -0.062 & 0.005 & 0.000 \\
\hline Clerks & -0.102 & 0.005 & 0.000 \\
\hline $\begin{array}{l}\text { Labourers and } \\
\text { Trade Workers }\end{array}$ & -0.084 & 0.005 & 0.000 \\
\hline Response & $*$ & $*$ & $*$ \\
\hline Region: & & & \\
\hline Auckland & -0.053 & 0.002 & 0.000 \\
\hline $\begin{array}{l}\text { Rest of North } \\
\text { Island }\end{array}$ & -0.064 & 0.002 & 0.000 \\
\hline South Island & -0.067 & 0.002 & 0.000 \\
\hline Missing/Overseas & -0.005 & 0.008 & 0.508 \\
\hline Wellington & $*$ & $*$ & $*$ \\
\hline
\end{tabular}

$*=$ omitted category 


\section{Appendix Three - Regression Two:}

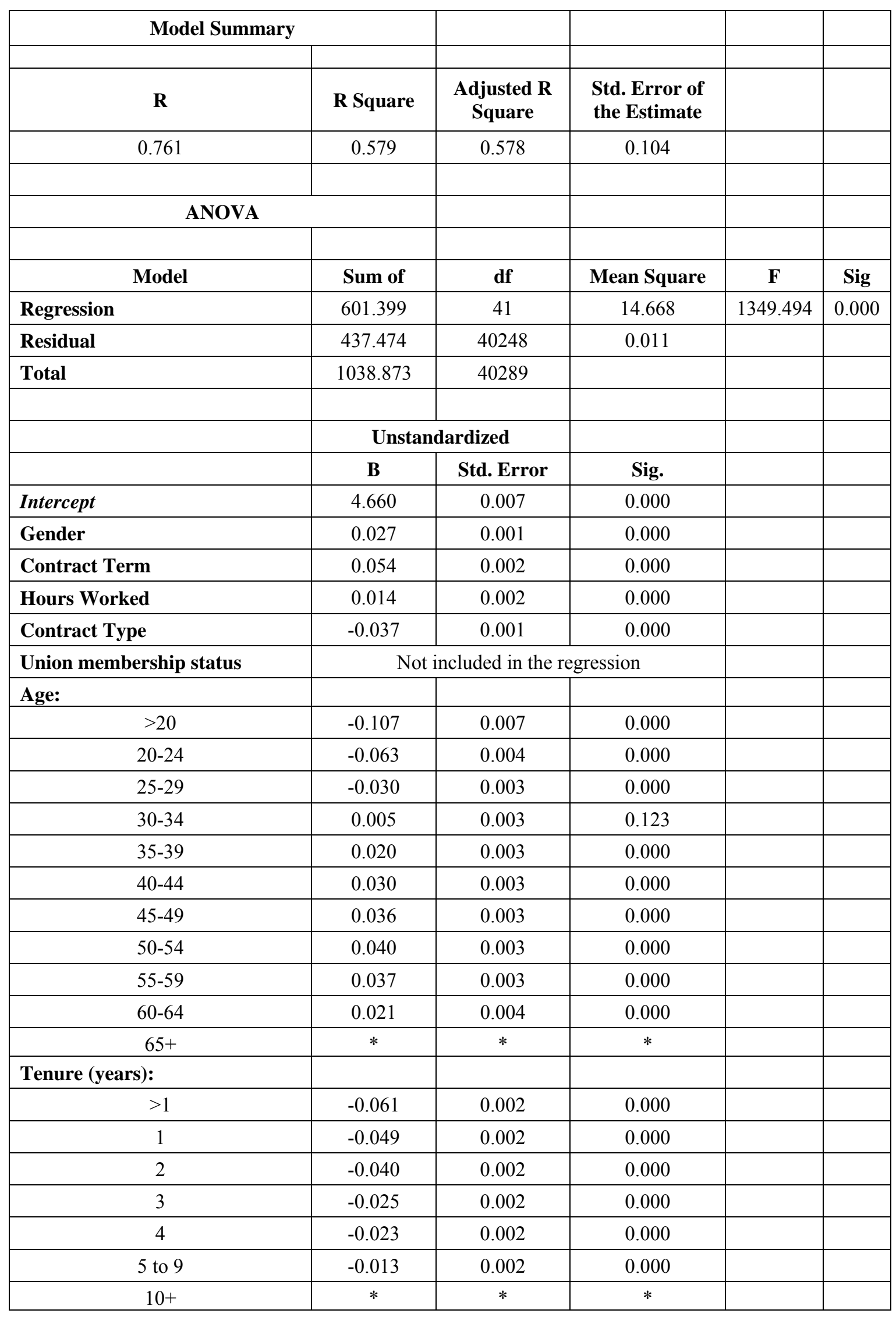




\begin{tabular}{|l|c|c|c|c|c|}
\hline Ethnicity: & & & & & \\
\hline Asians & 0.009 & 0.003 & 0.005 & & \\
\hline NZ European/Pakeha & 0.033 & 0.002 & 0.000 & & \\
\hline Maori & 0.020 & 0.003 & 0.000 & & \\
\hline Non-NZ European & 0.042 & 0.003 & 0.000 & & \\
\hline Other Ethnic Groups & 0.026 & 0.005 & 0.000 & & \\
\hline Unknown & 0.023 & 0.003 & 0.000 & & \\
\hline Pacific Islanders & $*$ & $*$ & $*$ & & \\
\hline Employer size (ees): & & & & & \\
\hline & 0.040 & 0.003 & 0.000 & & \\
\hline & 0.027 & 0.002 & 0.000 & & \\
\hline & $*$ & $*$ & $*$ & & \\
\hline Occupational category: & & & & & \\
\hline Legislative and admin & 0.259 & 0.015 & 0.000 & & \\
\hline Corporate manager & 0.148 & 0.005 & 0.000 & & \\
\hline $\begin{array}{l}\text { Physical, Mathematical \& } \\
\text { Engineering Science Professionals }\end{array}$ & 0.044 & 0.006 & 0.000 & & \\
\hline $\begin{array}{l}\text { Life Science \& Health } \\
\text { Professionals }\end{array}$ & 0.030 & 0.006 & 0.000 & & \\
\hline Teaching Professionals & -0.071 & 0.005 & 0.000 & & \\
\hline Other Professionals & 0.054 & 0.005 & 0.000 & & \\
\hline Associate Professionals & -0.063 & 0.005 & 0.000 & & \\
\hline Clerks & -0.103 & 0.005 & 0.000 & & \\
\hline Labourers and Trade Workers & -0.084 & 0.005 & 0.000 & & \\
\hline Response Unknown & $*$ & $*$ & $*$ & & \\
\hline Region: & -0.053 & 0.002 & 0.000 & & \\
\hline Auckland & -0.064 & 0.002 & 0.000 & & \\
\hline Rest of North Island & -0.067 & 0.002 & 0.000 & & \\
\hline South Island & -0.006 & 0.008 & 0.455 & & \\
\hline Missing/Overseas & $*$ & $*$ & $*$ & & \\
\hline Wellington & & & & & \\
\hline & & & & \\
\hline
\end{tabular}

$*=$ omitted category 


\section{Appendix Three - Regression Three:}

\begin{tabular}{|c|c|c|c|c|c|}
\hline \multicolumn{2}{|c|}{ Model Summary } & & \multirow[b]{2}{*}{$\begin{array}{l}\text { Std. Error of } \\
\text { the Estimate }\end{array}$} & & \\
\hline $\mathbf{R}$ & R Square & Adjusted R Square & & & \\
\hline 0.759 & 0.577 & 0.576 & 0.105 & & \\
\hline ANOVA & & & & & \\
\hline Model & Sum of Squares & df & Mean Square & $\mathbf{F}$ & Sig \\
\hline Regression & 599.088 & 41 & 14.612 & 1337.246 & 0.000 \\
\hline Residual & 439.785 & 40248 & 0.011 & & \\
\hline Total & 1038.873 & 40289 & & & \\
\hline & Unstandardize & & & & \\
\hline & B & Std. Error & Sig. & & \\
\hline Intercept & 4.658 & 0.007 & 0.000 & & \\
\hline Gender & 0.027 & 0.001 & 0.000 & & \\
\hline Contract Term & 0.048 & 0.002 & 0.000 & & \\
\hline Hours Worked & 0.017 & 0.002 & 0.000 & & \\
\hline Union & -0.031 & 0.001 & 0.000 & & \\
\hline Age: & & & & & \\
\hline$>20$ & -0.107 & 0.007 & 0.000 & & \\
\hline $20-24$ & -0.063 & 0.004 & 0.000 & & \\
\hline $25-29$ & -0.031 & 0.003 & 0.000 & & \\
\hline $30-34$ & 0.005 & 0.003 & 0.150 & & \\
\hline $35-39$ & 0.020 & 0.003 & 0.000 & & \\
\hline $40-44$ & 0.029 & 0.003 & 0.000 & & \\
\hline $45-49$ & 0.035 & 0.003 & 0.000 & & \\
\hline $50-54$ & 0.040 & 0.003 & 0.000 & & \\
\hline $55-59$ & 0.037 & 0.003 & 0.000 & & \\
\hline $60-64$ & 0.020 & 0.004 & 0.000 & & \\
\hline $65+$ & $*$ & $*$ & $*$ & & \\
\hline Tenure (years): & & & & & \\
\hline$>1$ & -0.058 & 0.002 & 0.000 & & \\
\hline 1 & -0.048 & 0.002 & 0.000 & & \\
\hline 2 & -0.038 & 0.002 & 0.000 & & \\
\hline 3 & -0.023 & 0.002 & 0.000 & & \\
\hline 4 & -0.022 & 0.002 & 0.000 & & \\
\hline 5 to 9 & -0.012 & 0.002 & 0.000 & & \\
\hline $10+$ & $*$ & $*$ & $*$ & & \\
\hline
\end{tabular}




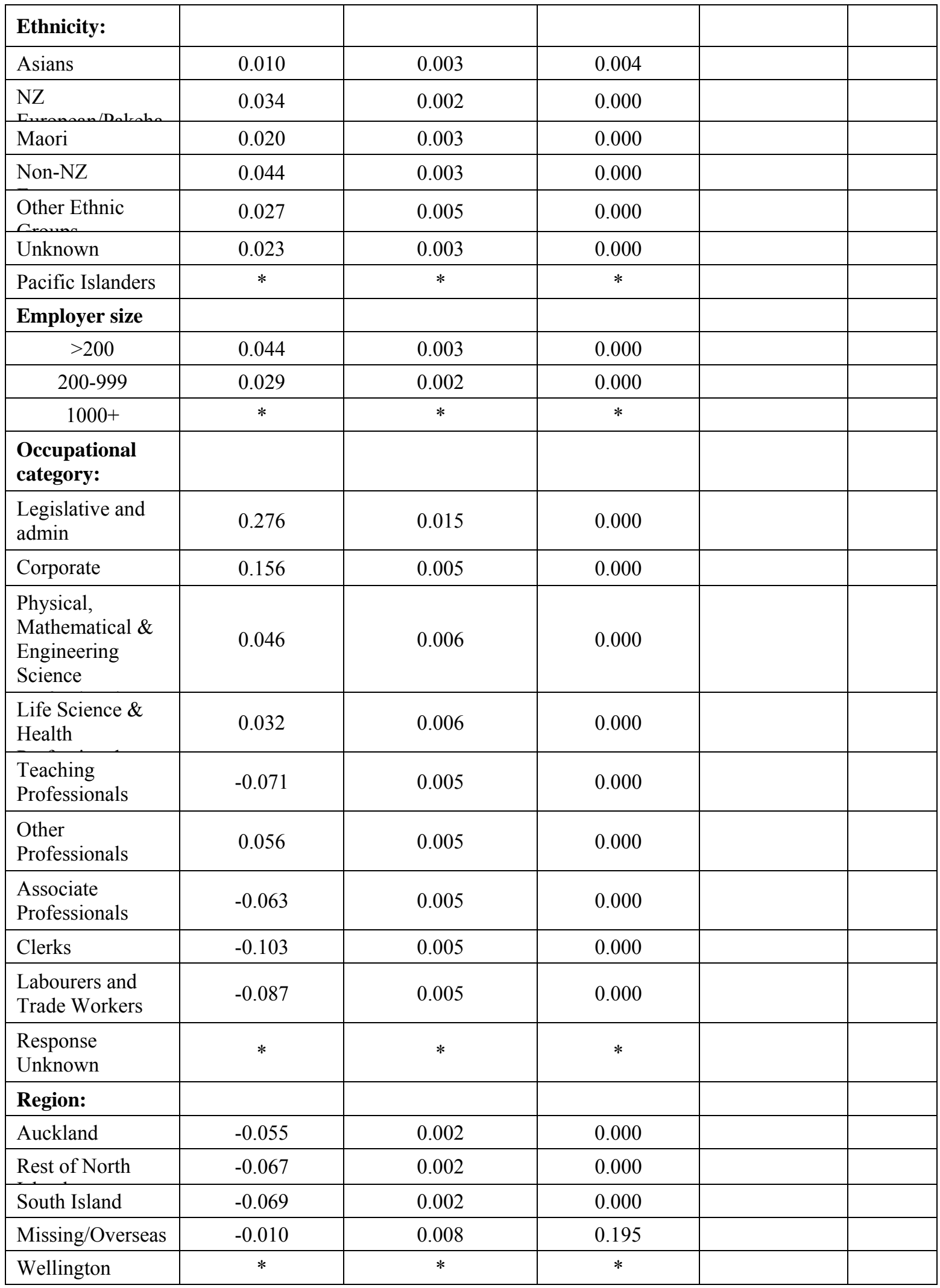

$*=$ omitted category 


\section{Appendix Three - Regression Four:}

\begin{tabular}{|c|c|c|c|c|c|}
\hline \multicolumn{3}{|c|}{ Model Summary } & \multirow[b]{2}{*}{$\begin{array}{l}\text { Std. Error of } \\
\text { the Estimate }\end{array}$} & & \\
\hline $\mathbf{R}$ & R Square & $\begin{array}{l}\text { Adjusted R } \\
\text { Square }\end{array}$ & & & \\
\hline 0.786 & 0.617 & 0.617 & 0.099 & & \\
\hline \multicolumn{6}{|l|}{ ANOVA } \\
\hline Model & Sum of Squares & df & Mean Square & $\mathbf{F}$ & Sig \\
\hline Regression & 641.422 & 80 & 8.018 & 811.136 & 0.000 \\
\hline Residual & 397.451 & 40209 & 0.010 & & \\
\hline \multirow[t]{3}{*}{ Total } & 1038.873 & 40289 & & & \\
\hline & \multicolumn{2}{|l|}{$\begin{array}{l}\text { Unstandardized } \\
\text { Coefficients }\end{array}$} & & & \\
\hline & B & Std. Error & Sig. & & \\
\hline Intercept & 4.655 & 0.008 & 0.000 & & \\
\hline Gender & 0.034 & 0.002 & 0.000 & & \\
\hline Contract Term & 0.035 & 0.002 & 0.000 & & \\
\hline Hours Worked & 0.026 & 0.003 & 0.000 & & \\
\hline Contract type & -0.021 & 0.013 & 0.113 & & \\
\hline \multicolumn{6}{|l|}{ Age: } \\
\hline$>20$ & -0.133 & 0.008 & 0.000 & & \\
\hline $20-24$ & -0.083 & 0.005 & 0.000 & & \\
\hline $25-29$ & -0.040 & 0.004 & 0.000 & & \\
\hline $30-34$ & 0.003 & 0.004 & 0.441 & & \\
\hline $35-39$ & 0.030 & 0.004 & 0.000 & & \\
\hline $40-44$ & 0.045 & 0.004 & 0.000 & & \\
\hline $45-49$ & 0.048 & 0.004 & 0.000 & & \\
\hline $50-54$ & 0.055 & 0.004 & 0.000 & & \\
\hline $55-59$ & 0.053 & 0.005 & 0.000 & & \\
\hline $60-64$ & 0.035 & 0.005 & 0.000 & & \\
\hline $65+$ & $*$ & $*$ & $*$ & & \\
\hline \multicolumn{6}{|l|}{ Tenure (years): } \\
\hline$>1$ & -0.053 & 0.003 & 0.000 & & \\
\hline 1 & -0.045 & 0.003 & 0.000 & & \\
\hline 2 & -0.040 & 0.003 & 0.000 & & \\
\hline 3 & -0.024 & 0.003 & 0.000 & & \\
\hline 4 & -0.021 & 0.004 & 0.000 & & \\
\hline
\end{tabular}




\begin{tabular}{|c|c|c|c|}
\hline 5 to 9 & -0.012 & 0.003 & 0.000 \\
\hline $10+$ & * & $*$ & * \\
\hline \multicolumn{4}{|l|}{ Ethnicity: } \\
\hline Asians & 0.012 & 0.004 & 0.007 \\
\hline $\begin{array}{l}\text { NZ } \\
\text { European/Pakeha }\end{array}$ & 0.041 & 0.003 & 0.000 \\
\hline Maori & 0.022 & 0.004 & 0.000 \\
\hline Non-NZ & 0.044 & 0.003 & 0.000 \\
\hline $\begin{array}{l}\text { Other Ethnic } \\
\text { Groups }\end{array}$ & 0.030 & 0.007 & 0.000 \\
\hline Unknown & 0.027 & 0.004 & 0.000 \\
\hline Pacific Islanders & * & $*$ & * \\
\hline \multicolumn{4}{|l|}{ Employer size } \\
\hline$>200$ & 0.033 & 0.004 & 0.000 \\
\hline 200-999 & 0.024 & 0.002 & 0.000 \\
\hline $1000+$ & $*$ & $*$ & * \\
\hline \multicolumn{4}{|l|}{$\begin{array}{l}\text { Occupational } \\
\text { category: }\end{array}$} \\
\hline $\begin{array}{l}\text { Legislative and } \\
\text { admin }\end{array}$ & 0.296 & 0.019 & 0.000 \\
\hline $\begin{array}{l}\text { Corporate } \\
\text { manager }\end{array}$ & 0.170 & 0.006 & 0.000 \\
\hline $\begin{array}{l}\text { Physical, } \\
\text { Mathematical \& } \\
\text { Engineering } \\
\text { Science } \\
\text { Professionals }\end{array}$ & 0.049 & 0.007 & 0.000 \\
\hline $\begin{array}{l}\text { Life Science \& } \\
\text { Health } \\
\text { Professionals }\end{array}$ & 0.077 & 0.008 & 0.000 \\
\hline $\begin{array}{l}\text { Teaching } \\
\text { Professionals }\end{array}$ & -0.147 & 0.007 & 0.000 \\
\hline $\begin{array}{l}\text { Other } \\
\text { Professionals }\end{array}$ & 0.065 & 0.006 & 0.000 \\
\hline $\begin{array}{l}\text { Associate } \\
\text { Professionals }\end{array}$ & -0.060 & 0.006 & 0.000 \\
\hline Clerks & -0.100 & 0.006 & 0.000 \\
\hline $\begin{array}{l}\text { Labourers and } \\
\text { Trade Workers }\end{array}$ & -0.104 & 0.007 & 0.000 \\
\hline $\begin{array}{l}\text { Response } \\
\text { Unknown }\end{array}$ & $*$ & $*$ & $*$ \\
\hline \multicolumn{4}{|l|}{ Region: } \\
\hline Auckland & -0.072 & 0.002 & 0.000 \\
\hline $\begin{array}{l}\text { Rest of North } \\
\text { Island }\end{array}$ & -0.089 & 0.002 & 0.000 \\
\hline South Island & -0.095 & 0.002 & 0.000 \\
\hline Missing/Overseas & -0.012 & 0.013 & 0.346 \\
\hline Wellington & * & $*$ & $*$ \\
\hline
\end{tabular}




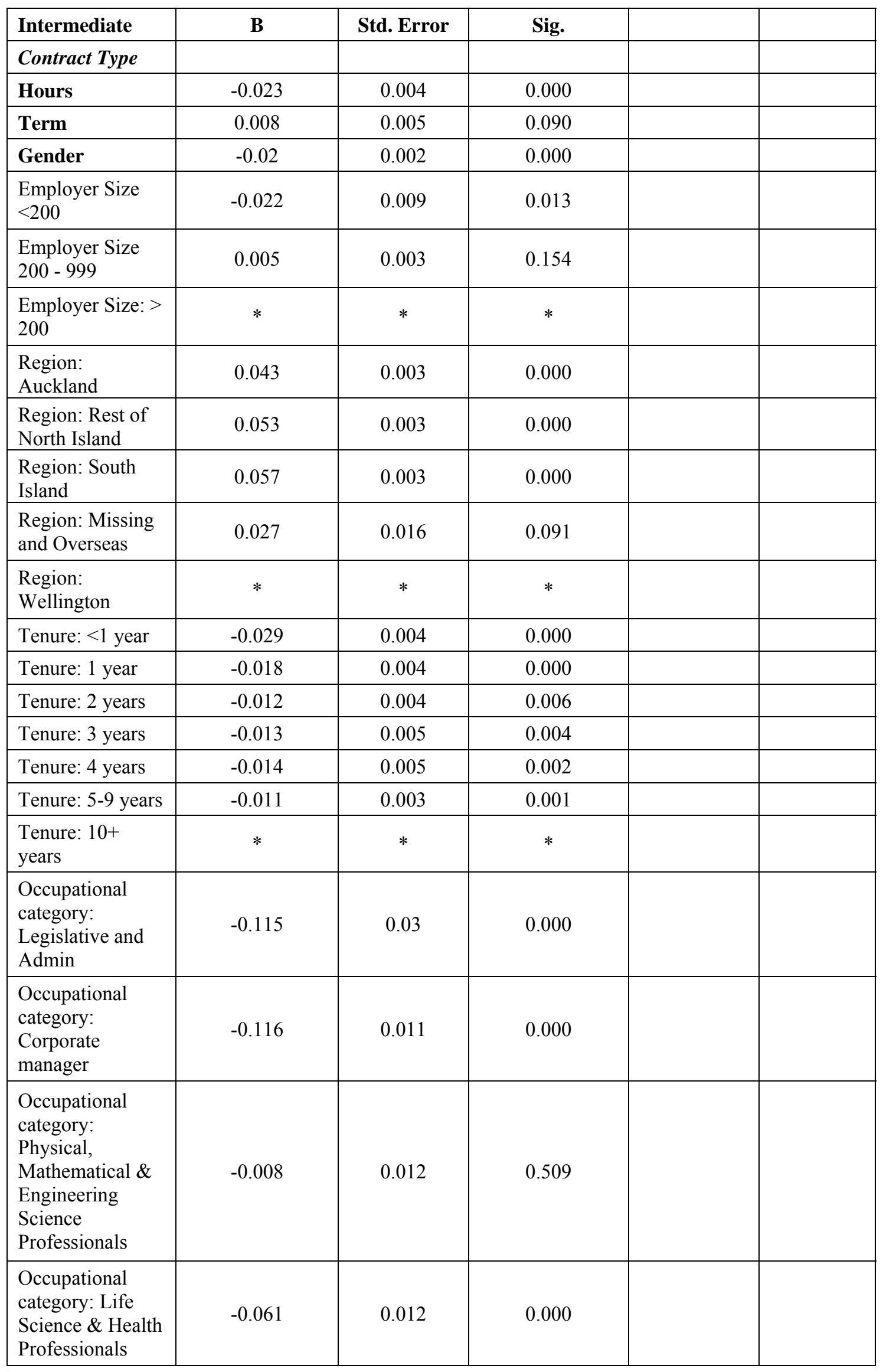




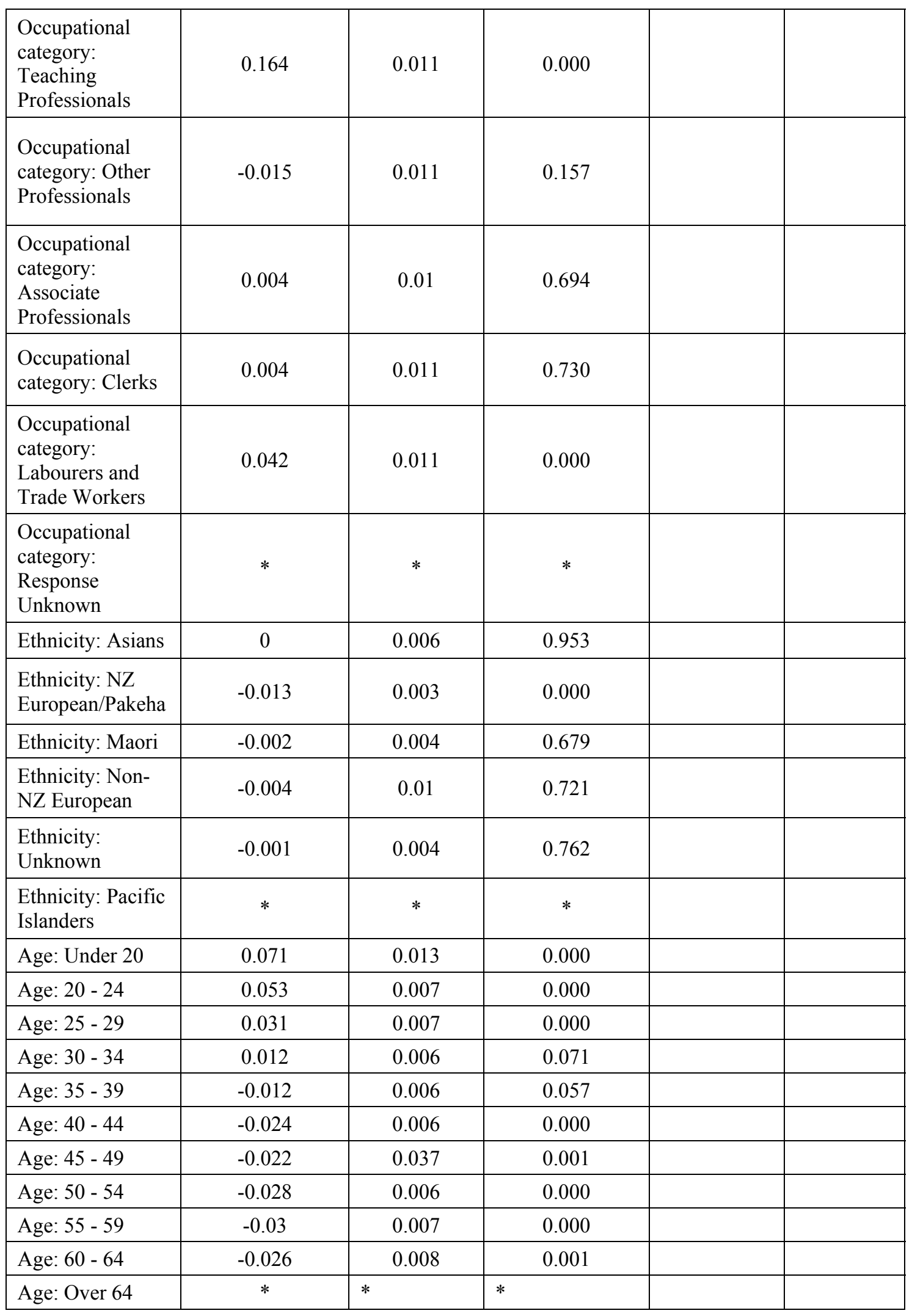

$*=$ omitted category 


\section{Appendix Three - Regression Five:}

\begin{tabular}{|c|c|c|c|c|c|}
\hline \multicolumn{2}{|c|}{ Model Summary } & \multirow{2}{*}{ Adjusted R } & \multirow{2}{*}{ Std. Error of } & & \\
\hline $\mathbf{R}$ & R Square & & & & \\
\hline 0.742 & 0.550 & 0.549 & 0.108 & & \\
\hline \multicolumn{2}{|c|}{ ANOVA } & & & & \\
\hline Model & Sum of & df & Mean Square & $\mathbf{F}$ & Sig \\
\hline Regression & 571.309 & 68 & 8.402 & 722.728 & 0.000 \\
\hline Residual & 467.563 & 40221 & 0.012 & & \\
\hline Total & 1038.873 & 40289 & & & \\
\hline & \multicolumn{2}{|c|}{ Unstandardized } & & & \\
\hline & B & Std. Error & Sig. & & \\
\hline Intercept & 0.468 & 0.006 & 0.000 & & \\
\hline Gender & 0.051 & 0.002 & 0.000 & & \\
\hline Contract Term & 0.085 & 0.002 & 0.000 & & \\
\hline Hours Worked & 0.049 & 0.003 & 0.000 & & \\
\hline Contract Type & -0.009 & 0.009 & 0.322 & & \\
\hline Union membership status & \multicolumn{3}{|c|}{ Not included in the regression } & & \\
\hline \multicolumn{6}{|l|}{ Age: } \\
\hline$>20$ & -0.123 & 0.009 & 0.000 & & \\
\hline $20-24$ & -0.082 & 0.005 & 0.000 & & \\
\hline $25-29$ & -0.043 & 0.005 & 0.000 & & \\
\hline $30-34$ & 0.002 & 0.005 & 0.064 & & \\
\hline $35-39$ & 0.03 & 0.005 & 0.000 & & \\
\hline $40-44$ & 0.048 & 0.005 & 0.000 & & \\
\hline $45-49$ & 0.055 & 0.005 & 0.000 & & \\
\hline $50-54$ & 0.066 & 0.005 & 0.000 & & \\
\hline $55-59$ & 0.062 & 0.005 & 0.000 & & \\
\hline $60-64$ & 0.038 & 0.006 & 0.000 & & \\
\hline $65+$ & $*$ & $*$ & $*$ & & \\
\hline \multicolumn{6}{|l|}{ Tenure (years): } \\
\hline$>1$ & -0.075 & 0.003 & 0.000 & & \\
\hline 1 & -0.069 & 0.003 & 0.000 & & \\
\hline 2 & -0.065 & 0.003 & 0.000 & & \\
\hline 3 & -0.048 & 0.004 & 0.000 & & \\
\hline 4 & -0.043 & 0.004 & 0.000 & & \\
\hline 5 to 9 & -0.029 & 0.003 & 0.000 & & \\
\hline $10+$ & * & $*$ & $*$ & & \\
\hline
\end{tabular}




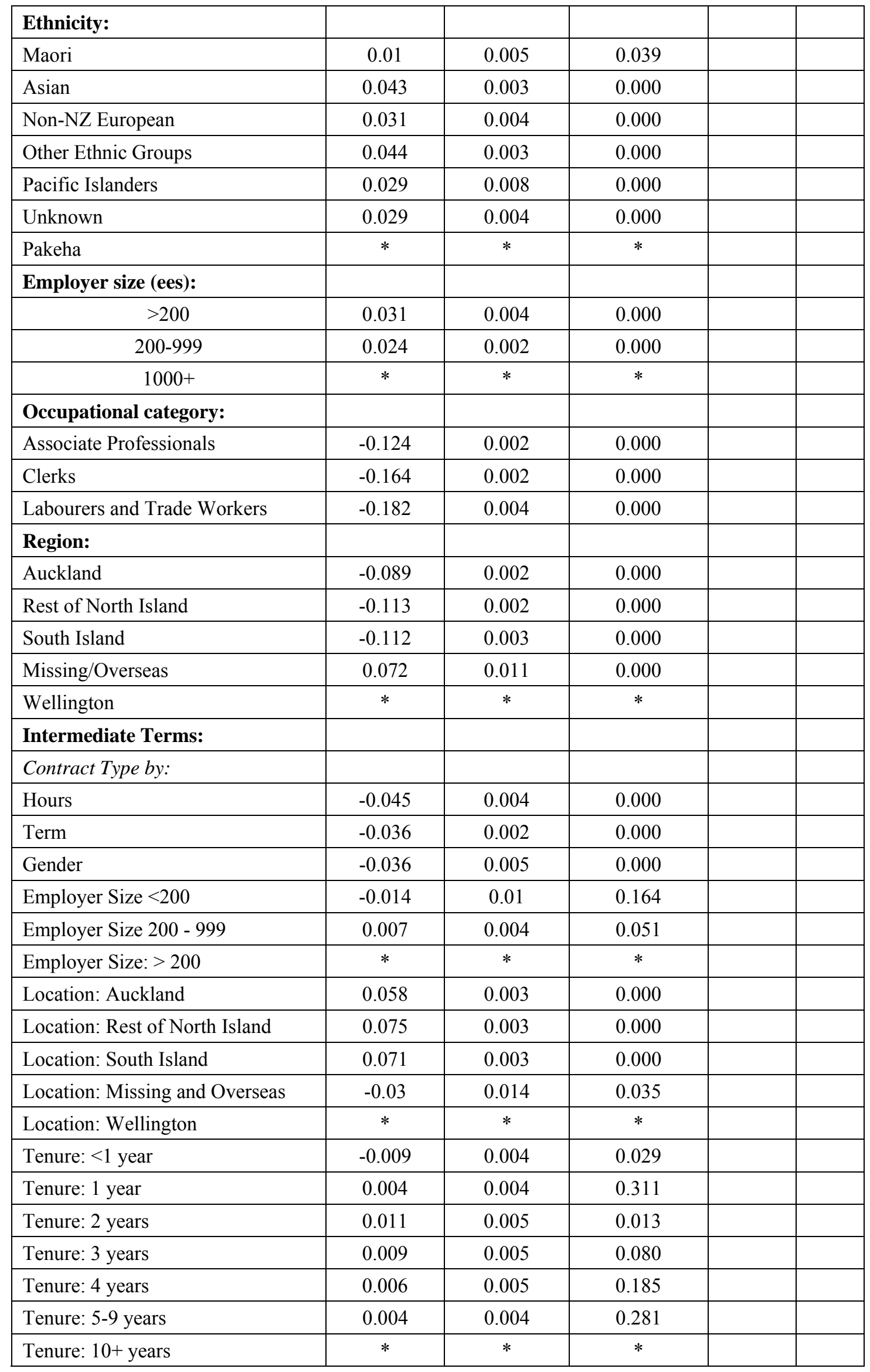




\begin{tabular}{|l|c|c|c|c|c|}
\hline $\begin{array}{l}\text { Occupational category: Legislative } \\
\text { and Admin }\end{array}$ & 0.029 & 0.003 & 0.000 & & \\
\hline $\begin{array}{l}\text { Occupational category: Corporate } \\
\text { manager }\end{array}$ & 0.028 & 0.003 & 0.000 & & \\
\hline $\begin{array}{l}\text { Occupational category: Physical, } \\
\text { Mathematical \& Engineering } \\
\text { Science Professionals }\end{array}$ & 0.082 & 0.005 & 0.000 & & \\
\hline Ethnicity: Maori & 0.004 & 0.006 & 0.507 & & \\
\hline Ethnicity: Asians & -0.015 & 0.003 & 0.000 & & \\
\hline Ethnicity: Non-NZ Europeans & -0.012 & 0.004 & 0.003 & & \\
\hline Ethnicity: Pacific Islander & -0.001 & 0.011 & 0.894 & & \\
\hline Ethnicity: Unknown & -0.003 & 0.004 & 0.528 & & \\
\hline Ethnicity: NZ European/Pakeha & $*$ & $*$ & $*$ & & \\
\hline Age: Under 20 & 0.064 & 0.014 & 0.000 & & \\
\hline Age: $20-24$ & 0.054 & 0.008 & 0.000 & & \\
\hline Age: $25-29$ & 0.036 & 0.007 & 0.000 & & \\
\hline Age: $30-34$ & 0.015 & 0.007 & 0.028 & & \\
\hline Age: $35-39$ & -0.01 & 0.007 & 0.148 & & \\
\hline Age: $40-44$ & -0.026 & 0.007 & 0.000 & & \\
\hline Age: $45-49$ & -0.028 & 0.007 & 0.000 & & \\
\hline Age: $50-54$ & -0.038 & 0.007 & 0.000 & & \\
\hline Age: $55-59$ & -0.039 & 0.007 & 0.000 & & \\
\hline Age: $60-64$ & -0.028 & 0.008 & 0.001 & & \\
\hline Age: Over 64 & $*$ & $*$ & $*$ & & \\
\hline
\end{tabular}

$*=$ omitted category

NB: The following Occupational categories have been left out - Administrators and Legislators, Corporate Managers and All Professionals 
Appendix Three - Regression Six:

\begin{tabular}{|c|c|c|c|c|c|}
\hline \multicolumn{4}{|c|}{ Individual Employment Agreement (IEA) Model } & & \\
\hline $\mathbf{R}$ & R Square & Adjusted R & Std. Error of & & \\
\hline 0.795 & 0.632 & 0.631 & 0.119 & & \\
\hline \multicolumn{6}{|c|}{ ANOVA } \\
\hline Model & Sum of & df & Mean Square & $\mathbf{F}$ & Sig \\
\hline Regression & 447.543 & 40 & 11.189 & 788.019 & 0.000 \\
\hline Residual & 260.838 & 18371 & 0.014 & & \\
\hline \multirow[t]{3}{*}{ Total } & 708.382 & 18411 & & & \\
\hline & \multicolumn{2}{|c|}{ Unstandardized } & & & \\
\hline & B & Std. Error & Sig. & & \\
\hline Intercept & 4.641 & 0.01 & 0.000 & & \\
\hline Gender & 0.034 & 0.002 & 0.000 & & \\
\hline Contract Term & 0.035 & 0.003 & 0.000 & & \\
\hline Hours Worked & 0.026 & 0.003 & 0.000 & & \\
\hline Union membership status & -0.003 & 0.002 & 0.120 & & \\
\hline \multicolumn{6}{|l|}{ Age: } \\
\hline$>20$ & -0.132 & 0.01 & 0.000 & & \\
\hline $20-24$ & -0.082 & 0.006 & 0.000 & & \\
\hline $25-29$ & -0.04 & 0.005 & 0.000 & & \\
\hline $30-34$ & 0.004 & 0.005 & 0.458 & & \\
\hline $35-39$ & 0.03 & 0.005 & 0.000 & & \\
\hline $40-44$ & 0.045 & 0.005 & 0.000 & & \\
\hline $45-49$ & 0.048 & 0.005 & 0.000 & & \\
\hline $50-54$ & 0.055 & 0.005 & 0.000 & & \\
\hline $55-59$ & 0.052 & 0.006 & 0.000 & & \\
\hline $60-64$ & 0.034 & 0.007 & 0.000 & & \\
\hline $65+$ & $*$ & $*$ & $*$ & & \\
\hline \multicolumn{6}{|l|}{ Tenure (years): } \\
\hline$>1$ & -0.054 & 0.003 & 0.000 & & \\
\hline 1 & -0.046 & 0.003 & 0.000 & & \\
\hline 2 & -0.041 & 0.004 & 0.000 & & \\
\hline 3 & -0.025 & 0.004 & 0.000 & & \\
\hline 4 & -0.021 & 0.004 & 0.000 & & \\
\hline 5 to 9 & -0.013 & 0.003 & 0.000 & & \\
\hline $10+$ & $*$ & $*$ & $*$ & & \\
\hline
\end{tabular}




\begin{tabular}{|l|c|c|c|l|l|}
\hline Ethnicity: & & & & & \\
\hline Maori & 0.027 & 0.006 & 0.000 & & \\
\hline Asian & 0.056 & 0.005 & 0.000 & & \\
\hline Non-NZ European & 0.037 & 0.005 & 0.000 & & \\
\hline Other Ethnic Groups & 0.066 & 0.005 & 0.000 & & \\
\hline Pacific Islanders & 0.045 & 0.009 & 0.000 & & \\
\hline Unknown & 0.042 & 0.005 & 0.000 & & \\
\hline Pakeha & $*$ & $*$ & $*$ & & \\
\hline Employer size (ees): & & & & & \\
\hline & 0.034 & 0.004 & 0.000 & & \\
\hline & 0.024 & 0.003 & 0.000 & & \\
\hline & $*$ & $*$ & $*$ & & \\
\hline Occupational category: & & & & & \\
\hline Legislative and admin & 0.296 & 0.023 & 0.000 & & \\
\hline Corporate manager & 0.171 & 0.007 & 0.000 & & \\
\hline $\begin{array}{l}\text { Physical, Mathematical \& } \\
\text { Engineering Science }\end{array}$ & 0.049 & 0.008 & 0.000 & & \\
\hline Professionals & -0.071 & 0.003 & 0.000 & & \\
\hline $\begin{array}{l}\text { Life Science \& Health } \\
\text { Professionals }\end{array}$ & 0.076 & 0.009 & 0.000 & & \\
\hline Teaching Professionals & -0.146 & 0.008 & 0.000 & & \\
\hline Other Professionals & 0.065 & 0.007 & 0.000 & & \\
\hline Associate Professionals & -0.06 & 0.007 & 0.000 & & \\
\hline Clerks & -0.1 & 0.007 & 0.000 & & \\
\hline Labourers and Trade Workers & -0.102 & 0.008 & 0.000 & & \\
\hline Response Unknown & $*$ & $*$ & $*$ & & \\
\hline Region: & -0.095 & 0.003 & 0.000 & & \\
\hline Auckland & $*$ & $*$ & & & \\
\hline Rest of North Island & & & & & \\
\hline South Island & -0.012 & & & & \\
\hline Missing/Overseas & & & & & \\
\hline Wellington & & & & & \\
\hline
\end{tabular}

$*=$ omitted category 
Appendix Three - Regression Six:

\begin{tabular}{|c|c|c|c|c|c|}
\hline \multicolumn{4}{|c|}{ Collective Employment Agreement (CEA) Model } & & \\
\hline $\mathbf{R}$ & R Square & Adjusted R & Std. Error of & & \\
\hline 0.697 & 0.486 & 0.485 & 0.079 & & \\
\hline \multicolumn{6}{|c|}{ ANOVA } \\
\hline Model & Sum of & df & Mean Square & $\mathbf{F}$ & Sig \\
\hline Regression & 128.310 & 41 & 3.130 & 503.700 & 0.000 \\
\hline Residual & 135.668 & 21836 & 0.006 & & \\
\hline \multirow{3}{*}{ Total } & 263.978 & 21877 & & & \\
\hline & \multicolumn{2}{|c|}{ Unstandardized } & & & \\
\hline & $\mathbf{B}$ & Std. Error & Sig. & & \\
\hline Intercept & 4.654 & 0.008 & 0.000 & & \\
\hline Gender & 0.015 & 0.001 & 0.000 & & \\
\hline Contract Term & 0.044 & 0.003 & 0.000 & & \\
\hline Hours Worked & 0.005 & 0.002 & 0.007 & & \\
\hline Contract Type & $*$ & $*$ & $*$ & & \\
\hline Union membership status & -0.015 & 0.002 & 0.000 & & \\
\hline \multicolumn{6}{|l|}{ Age: } \\
\hline$>20$ & -0.06 & 0.008 & 0.000 & & \\
\hline $20-24$ & -0.029 & 0.004 & 0.000 & & \\
\hline $25-29$ & -0.009 & 0.004 & 0.027 & & \\
\hline $30-34$ & 0.016 & 0.004 & 0.000 & & \\
\hline $35-39$ & 0.019 & 0.004 & 0.000 & & \\
\hline $40-44$ & 0.022 & 0.004 & 0.000 & & \\
\hline $45-49$ & 0.027 & 0.004 & 0.000 & & \\
\hline $50-54$ & 0.028 & 0.004 & 0.000 & & \\
\hline $55-59$ & 0.024 & 0.004 & 0.000 & & \\
\hline $60-64$ & 0.01 & 0.004 & 0.013 & & \\
\hline $65+$ & $*$ & $*$ & $*$ & & \\
\hline \multicolumn{6}{|l|}{ Tenure (years): } \\
\hline$>1$ & -0.084 & 0.002 & 0.000 & & \\
\hline 1 & -0.064 & 0.002 & 0.000 & & \\
\hline 2 & -0.053 & 0.002 & 0.000 & & \\
\hline 3 & -0.038 & 0.002 & 0.000 & & \\
\hline 4 & -0.035 & 0.002 & 0.000 & & \\
\hline 5 to 9 & -0.024 & 0.002 & 0.000 & & \\
\hline $10+$ & $*$ & $*$ & $*$ & & \\
\hline
\end{tabular}




\begin{tabular}{|l|c|c|c|c|c|}
\hline Ethnicity: & & & & & \\
\hline Maori & 0.005 & 0.003 & 0.155 & & \\
\hline Asian & 0.02 & 0.002 & 0.000 & & \\
\hline Non-NZ European & 0.01 & 0.003 & 0.000 & & \\
\hline Other Ethnic Groups & 0.028 & 0.003 & 0.000 & & \\
\hline Pacific Islanders & 0.018 & 0.006 & 0.002 & & \\
\hline Unknown & 0.017 & 0.003 & 0.000 & & \\
\hline Pakeha & $*$ & $*$ & $*$ & & \\
\hline Employer size (ees): & & & & & \\
\hline & 0.01 & 0.007 & 0.115 & & \\
\hline \multicolumn{1}{|c|}{ 200-9900+ } & 0.03 & 0.002 & 0.000 & & \\
\hline & $*$ & $*$ & $*$ & & \\
\hline Occupational category: & & & & & \\
\hline Legislative and admin & 0.181 & 0.018 & 0.000 & & \\
\hline Corporate manager & 0.005 & 0.007 & 0.000 & & \\
\hline $\begin{array}{l}\text { Physical, Mathematical \& } \\
\text { Engineering Science } \\
\text { Professionals }\end{array}$ & 0.04 & 0.008 & 0.000 & & \\
\hline $\begin{array}{l}\text { Life Science \& Health } \\
\text { Professionals }\end{array}$ & 0.017 & 0.008 & 0.028 & & \\
\hline Teaching Professionals & 0.014 & 0.007 & 0.056 & & \\
\hline Other Professionals & 0.05 & 0.007 & 0.000 & & \\
\hline Associate Professionals & -0.057 & 0.007 & 0.000 & & \\
\hline Clerks & -0.097 & 0.007 & 0.000 & & \\
\hline Labourers and Trade Workers & -0.066 & 0.007 & 0.000 & & \\
\hline Response Unknown & $*$ & $*$ & $*$ & & \\
\hline Region: & -0.029 & 0.002 & 0.000 & & \\
\hline Auckland & -0.035 & 0.002 & 0.000 & & \\
\hline Rest of North Island & 0.014 & 0.007 & 0.059 & & \\
\hline South Island & $*$ & $*$ & $*$ & & \\
\hline Missing/Overseas & & & & & \\
\hline Wellington & & & & \\
\hline
\end{tabular}

* = omitted category 